(DECEMBER

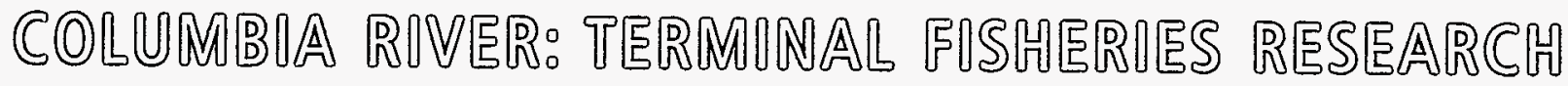

REPORT

\title{
Annual Report 1994
}

$$
\text { DOE/BP - } 05409-1
$$

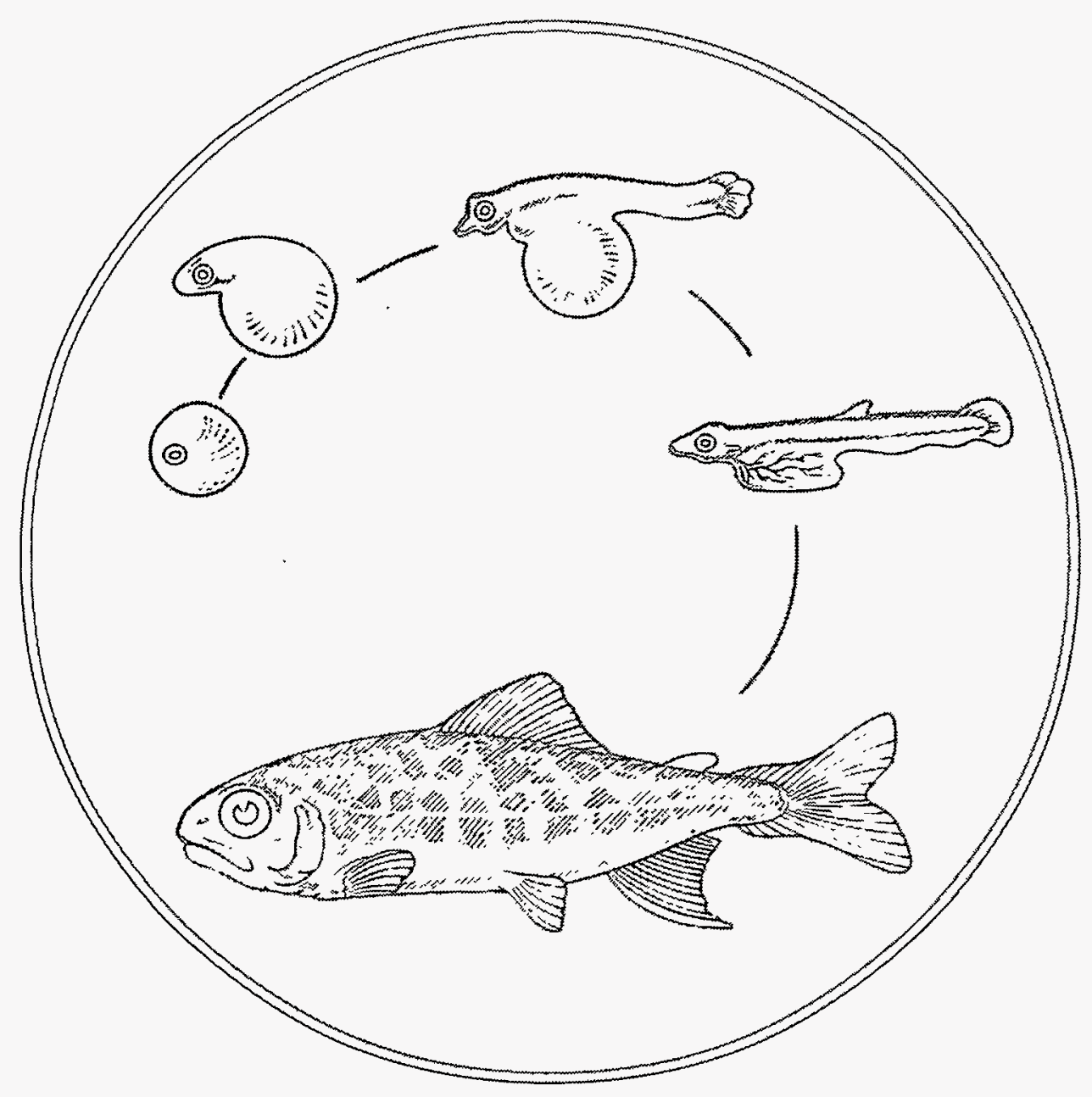


This report was funded by the Bonneville Power Administration (BPA), U.S. Department of Energy, as part of BPA's program to protect, mitigate, and enhance fish and wildlife affected by the development and operation of hydroelectric facilities on the Columbia River and its tributaries. The views in this report are the author's and do not necessarily represent the views of BPA.

\title{
DISCLAIMER
}

This report was prepared as an account of work sponsored by an agency of the United States Government. Neither the United States Government nor any agency thereof, nor any of their employees, makes any warranty, express or implied, or assumes any legal liability or responsibility for the accuracy, completeness, or usefulness of any information, apparatus, product, or process disclosed, or represents that its use would not infringe privately owned rights. Reference herein to any specific commercial product, process, or service by trade name, trademark, manufacturer, or otherwise does not necessarily constitute or imply its endorsement, recommendation, or favoring by the United States Government or any agency thereof. The views and opinions of authors expressed herein do not necessarily state or reflect those of the United States Government or any agency thereof.

For additional copies of this report, write to:

\author{
Bonneville Power Administration \\ Public Information Center - CKPS-1 \\ P.O. Box 3621 \\ Portland, OR 97208
}

Please include title, author, and DOE/BP number from the back cover in the request. 


\section{DISCLAIMER}

Portions of this document may be illegible electronic image products. Images are produced from the best available original document. 


\title{
COLUMBIA RIVER: TERMINAL FISHERIES RESEARCH PROJECT
}

\author{
1994 ANNUAL REPORT \\ Prepared by: \\ Paul Hirose \\ Oregon Department of Fish and Wildlife \\ Marc Miller \\ Washington Department of Fish and Wildlife \\ and \\ Jim Hill \\ Clatsop County Economic Development Committee
}

Prepared for:

U. S. Department of Energy

Bonneville Power Administration

Environment, Fish and Wildlife

P.O. Box 3621.

Project Number 93-060

Contract Numbers 93BI05409 and 93BI04982

DECEMBER 1996

DISTRIBUTION OF THIS DOCURAENT IS UNLIMITED 


\section{TABLE OF CONTENTS}

Page

TABLE OF CONTENTS $\ldots \ldots \ldots \ldots \ldots \ldots \ldots \ldots \ldots \ldots \ldots \ldots$

LIST OF TABLES $\ldots \ldots \ldots \ldots \ldots \ldots \ldots \ldots \ldots \ldots \ldots \ldots \ldots$ iv

LIST OF FIGÜRES $\ldots \ldots \ldots \ldots \ldots \ldots \ldots \ldots \ldots \ldots \ldots \ldots \ldots \ldots \ldots \ldots$

EXECUTIVE SUMMARY $\ldots \ldots \ldots \ldots \ldots \ldots \ldots \ldots \ldots \ldots \ldots \ldots \ldots$

INTRODUCTION $\ldots \ldots \ldots \ldots \ldots \ldots \ldots \ldots \ldots \ldots \ldots \ldots \ldots \ldots \ldots \ldots 4$

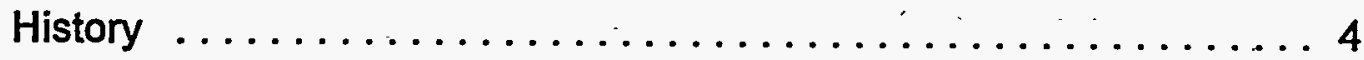

Description of Current 10 -Year Project ............... 5

Description of Work for Current Year. $(1993-94) \ldots \ldots \ldots \ldots \ldots 6$

CHAPTER 1. SURVEY AND CATEGORIZATION OF POTENTIAL

TERMINAL FISHERY SITES $\ldots \ldots \ldots \ldots \ldots \ldots \ldots \ldots \ldots \ldots$

A. Selection of Terminal Fisheries Sites ............. 11

B. Physical Dimensions and Flow Characteristics ......... 28

CHAPTER 2. CAPABILITY OF SITES FOR REARING AND ACCLIMATING ANADROMOUS SPECIES IN NET PENS . . . . . 33
A. Water Quality Literature $\ldots \ldots \ldots \ldots \ldots \ldots \ldots \ldots \ldots \ldots$
B. Water Quality Sampling .................... 35
C. Estimates of Homing and Straying Rates by Site and Fish Stock. 36
D. Disease Projections for High Terminal Rearing Sites ....... 41

CHAPTER 3. CAPABILITY OF TERMINAL FISHING SITES TO ALLOW MANAGEABLE AND ECONOMICALLY COMPETITIVE HARVEST OF RETURN FISH $\ldots \ldots \ldots \ldots \ldots \ldots \ldots \ldots \ldots \ldots \ldots \ldots \ldots 43$

A. Site Fishability .................... 43

B. Application of Various Fishing Gear Types to Terminal Sites . . . 49

CHAPTER 4. POTENTIAL FOR HARVEST OF TARGET AND NONTARGET FISH SPECIES $\ldots \ldots \ldots \ldots \ldots \ldots \ldots \ldots \ldots \ldots \ldots . \ldots 1$

A. 1994 Spring Test Fishery in Potential Terminal Fishing Sites . . 51 
B. 1994 Fall Test Fishery in Potential Terminal Fishing Sites .... 63

CHAPTER 5. SUITABILITY OF VARIOUS ANADROMOUS FISH STOCKS FOR USE IN TERMINAL FISHERIES $\ldots \ldots \ldots \ldots \ldots \ldots \ldots$

A. Native Stocks and Compatibility Issues $\ldots \ldots \ldots \ldots \ldots \ldots 74$

B. Availability and Suitability of Hatchery Fish $\ldots \ldots \ldots \ldots \ldots 77$

CHAPTER 6. COST AND LOGISTICS OF'A LARGE SCALE REARING AND RELEASE PROGRAM FOR POTENTIAL TERMINAL FISHING SITES $\ldots \ldots \ldots \ldots \ldots \ldots \ldots \ldots \ldots .65$

A. Production Capability by Site $\ldots \ldots \ldots \ldots \ldots \ldots \ldots \ldots, 85$

B. Estimated Cost by Site ................... 91

C. Columbia River Terminal Fishery Development Scenario ..... 95

CHAPTER 7. DESCRIPTION OF OPERATIONAL REPERCUSSIONS OF TERMINAL FISHERIES PROGRAMS ON EXISTING HATCHERY PROGRAMS $\ldots \ldots \ldots \ldots \ldots \ldots \ldots \ldots \ldots \ldots \ldots \ldots . \ldots \ldots$

CHAPTER 8. EFFECTS OF SHIFTING VARIOUS LEVELS OF BELOWBONNEVILLE COMMERCIAL FISHERIES TO TERMINAL SITES ON UPRIVER FISH RUNS, ESCAPEMENTS, AND ABOVE-BONNEVILLE

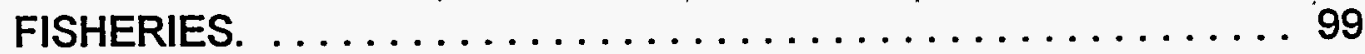

ACKNOWLEDGEMENTS $\ldots \ldots \ldots \ldots \ldots \ldots \ldots \ldots \ldots \ldots \ldots \ldots \ldots \ldots \ldots \ldots$

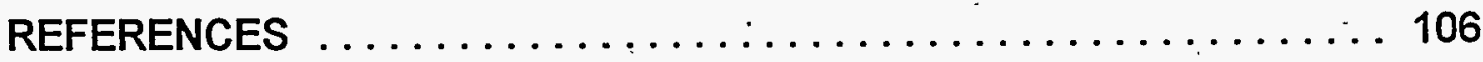

APPENDIX 1. COLUMBIA RIVER: TERMINAL FISHERIES RESEARCH PROJECT 1993-94 GOALS AND OBJECTIVES . . ......... 110

APPENDIX 2. RAW SAMPLE DATA FROM 1994 SPRING TEST FISHERY, IN NUMBERS OF FISH AND HOURS FISHED BY SPECIES, SITE, DATE AND TIME . ............... 114

APPENDIX 3. RAW SAMPLE DATA FROM 1994 FALL TEST FISHERY, IN NUMBERS OF FISH AND HOURS FISHED BY SPECIES, SITE, DATE AND TIME $\ldots \ldots \ldots \ldots \ldots \ldots \ldots \ldots \ldots \ldots \ldots \ldots \ldots$ 
Page

APPENDIX 4. DOCUMENTATION OF ESTIMATES OF SURVIVAL

RATES AND DISTRIBUTION IN FISHERIES FOR SELECTED

SPECIES AND STOCKS OF COLUMBIA RIVER SALMON

CONSIDERED FOR USE IN TERMINAL FISHERIES . . . . . . 122

APPENDIX 5. TERMINAL FISHERY CAPITALIZATION $\ldots \ldots \ldots \ldots \ldots 124$

APPENDIX 6. TERMINAL FISHERY OPERATION AND MAINTENANCE . -128

FIGURES

143 



\section{LIST OF TABLES}

Table

Page

1. Columbia River terminal area commercial fishing seasons and

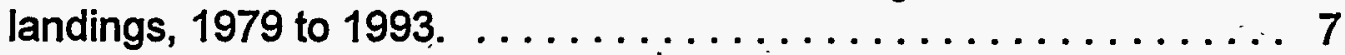

2. Releases of coho salmon into Youngs Bay, 1977 to $1993 . \ldots \ldots .9$

3. Releases of fall chinook into Youngs Bay, 1977 to $1993 . \ldots \ldots 10$

4. Releases of Willamette stock spring chinook into Youngs Bay,

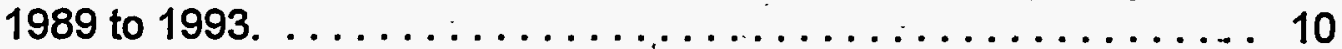

5. Ranking of potential tèrminal fishery sites below Bonneville Dam. . 27

6. Surface area of proposed harvest sites (square miles), minimum depth at pen sites (feet), and maximum flood and ebb flows (knots) at terminal fishery sites, $1994 \ldots \ldots \ldots \ldots \ldots \ldots \ldots \ldots \ldots . \ldots \ldots$

7. Homing and straying of Rogue River Bright stock fall chinook, 1984-93. . . . . . . . . . . . . . . . . . . . . . . 39

8. Escapement accountability of adult coho resulting from releases into Youngs Bay-at S.F. Klaskanine Hatchery, N.F. Klaskanine Hatchery, and Tide Point net pen site, $1988-90$ broods. . . . . 40

9. Percentage mortality and incidence of disease for Youngs Bay net pen reared salmon, 1987-93 broods.

10. Selected peak daily catches and deliveries for past Columbia River terminal fisheries.

11. Capability for harvest in high priority sites in terms of numbers of boats.

12. Minimum numbers (in thousands of adults) of lower river spring chinook, upriver spring chinook, and lower river summer steelhead entering the Columbia River, $1980-94 . \ldots \ldots \ldots \ldots .58$

13. Net specifications for 1994 spring terminal test fishery, by site. . . 59 
14. Spring terminal test fishery catch and CPUE, by area, 1994. . . 60

15. Spring terminal test fishery catch, by site and date, 1994. . . . 61

16. Comparative catch and CPUE by mesh size of spring terminal test fishery, 1994.

17. Comparative day and night catch and CPUE in spring terminal test fishery, 1994.

18. Minimum numbers (in thousands of adults) of lower river and upriver fall chinook, coho, and group B summer steelhead entering the Columbia River, $1980-94 \ldots \ldots \ldots \ldots \ldots \ldots \ldots . \ldots 69$

19. Net specifications for 1994 fall terminal test fishery, by site. . . . . 70

20. Fall terminal test fishery catch and CPUE, by area, 1994. . . . . 71

21. Fall terminal test fishery catch, by site and date, $1994 \ldots \ldots \ldots 72$

22. Comparative catch and CPUE by mesh size of fall terminal test fishery, 1994.

23. Comparative day and night catch and CPUE in fall terminal test fishery, 1994. 73

24. Status of Oregon native salmonid stocks below Bonnevilie Dam. . . 75

25. Status of Washington native salmonid stocks below Bonneville Dam. .............................. 76

26. Biological characteristics of hatchery salmon stocks considered for potential use in lower Columbia River terminal fisheries. . . . 79

27. Estimated survival rates (percent) for hatchery salmon stocks considered for potential use in Lower Columbia River terminal fisheries.

28. Annual smolt production ceiling for unlisted species in the Columbia River Basin established in NMFS Proposed Recovery Plan, March 1995. 
29. Projected smolt releases after acclimation and rearing, by site. . . 92

30. Capitalization cost estimates for proposed terminal fishery sites. . . 94

31. Operation and maintenance cost estimates for proposed terminal fishery sites. . . . . . . . . . . . . . . . 94

32. Average harvest rates for Willamette spring chinook in Columbia River mainstem fisheries, $1970-94 . \ldots \ldots \ldots \ldots \ldots \ldots . .98$

33. Release site operation plans. . . . . . . . . . . . . 98

34. Projected impacts on wild Snake River fall chinook on various harvest reductions in the lower Columbia River commercial fishery with various pass-through rates and two different dam passage conversions. .......................... 103

35. Projected impacts on Upriver Bright fall chinook at various harvest reductions in the lower Columbia River commercial fishery with various pass-through rates and two different dam passage conversions. ............................ 104 



\section{LIST OF FIGURES}

Figure

1. Lower Columbia River terminal fishery sites $\ldots \ldots \ldots \ldots \ldots 143$

2. Youngs Bay terminal fishery area $\ldots \ldots \ldots \ldots \ldots \ldots \ldots \ldots \ldots$

3. Tongue Point terminal fishery area $\ldots \ldots \ldots \ldots \ldots \ldots . \ldots \ldots$

4. Deep River terminal fishery area $\ldots \ldots \ldots \ldots \ldots \ldots \ldots$

5. Blind Slough terminal fishery area . . . . . . . . . . . 147

6. Steamboat Slough terminal fishery area $\ldots \ldots \ldots \ldots \ldots \ldots 148$

7. Clifton Channel terminal fishery area ............. 149

8. Cathlamet Channel terminal fishery area $\ldots \ldots \ldots \ldots \ldots . \ldots 150$

9. Wallace Slough terminal fishery area $\ldots \ldots \ldots \ldots \ldots \ldots 1$ 


\section{EXECUTIVE SUMMARY}

Columbia River terminal fisheries have been conducted in Youngs Bay, Oregon, since the early 1960's targeting coho salmon produced at the state facility on the North Fork Klaskanine River. In 1977 the Clatsop County Economic Development Council's (CEDC) Fisheries Project began augmenting the Oregon Department of Fish and Wildlife production efforts. Together ODFW and CEDC smolt releases totaled $5,060,000$ coho and 41.1,300 spring chinook in 1993 with most of the releases from the net pen acclimation program. During 1980-82 fall commercial terminal fisheries were conducted adjacent to the mouth of Big Creek in Oregon. All past terminal fisheries were successful in harvesting surplus hatchery fish with minimal impact on nonlocal weak stocks.

In 1993 the Northwest Power Planning Council recommended in its' Strategy for Salmon that terminal fishing sites be identified and developed. The Council called on the Bonneville Power Administration to fund a 10-year study to investigate the feasibility of creating and expanding terminal known stock fisheries in the Columbia River Basin. The findings of the initial year of the study are included in this report. The geographic area considered for study extends from Bonneville Dam to the river mouth.

The initial year's work is the beginning of a 2-year research stage to investigate potential sites, salmon stocks, and methodologies; a second 3-year stage will focus on expansion in Youngs Bay and experimental releases into sites with greatest potential; and a final 5-year phase establishing programs at full capacity at all acceptable sites.

After ranking all possible sites using five harvest and five rearing criteria, four sites in Oregon (Tongue Point, Blind Slough, Clifton Channel and Wallace Slough) and three in Washington (Deep River, Steamboat Slough and Cathlamet Channel) were chosen for study. In addition to the seven new sites, the established Youngs Bay site was included for further expansion.

Determination of the capability of the study sites for rearing and acclimation of juvenile salmon in net pens require monitoring of water quality and benthic biomonitoring. $A$ sampling plan was initiated in the 1994 fall period which includes bimonthly measurement of physiochemical parameters and quarterly benthic biomonitoring. The ability of adult salmon to home to the study site is dependant on their degree of success acclimating and imprinting while reared at the study sites. Experiments in = Youngs Bay using 1988-90 brood early stock coho show strong homing efficiency for net pen releases. Homing rates of $98 \%$ for hatcheries on south and north forks of the Klaskanine Rivers and $99 \%$ for net pens in Youngs Bay were observed. Homing rates for hatchery releases are in excess of $99 \%$ for Willamette and Cowlitz spring chinook, greater than $95 \%$ for Upriver Bright (URB) fall chinook, and about $90 \%$ for Rogue River Bright (RRB) fall chinook. Homing rates for net pen releases of chinook are not yet 
available but are expected to be similar to those observed for hatchery releases. Disease potential affects the capability of sites for rearing and is believed to be low, not a limiting factor for overwinter rearing and short-term acclimation. Past experience in Youngs Bay shows full term rearing through summer months of coho and spring chinook in net pens is associated with high water temperatures and furunculosis outbreaks. For RRB fall chinook disease potential is greater with smolts released as late as August 1.

Capability of terminal fishery sites to provide manageable, orderly, and economically competitive harvest of returning fish is desired. Issues raised by the fishing industry group Salmon for All (SFA) were orderly harvest to accommodlate up to 800 gillnet permit holders, terminal fisheries not intended to replace mainstem harvest opportunities, a cooperative approach to resource allocation and utilization amongst commercial and recreational users, and the commitment of agencies and users to maintain the terminal fisheries concept. Estimated number of boats that the new terminal sites could accommodate is 349 based on densities observed for past terminal fisheries. Presently, conventional gillnet gear is in use in the Youngs Bay terminal fishery with acceptable interception rates associated with nontargeted stocks. If use of conventional gillnet gear in terminal fisheries result in unacceptable levels of mortality on nontarget fish, use of live-capture gear types may be necessary.

To assess the harvest potential of terminal fishing areas, test gillnet fisheries were conducted during the spring and fall in 1994 at all seven study sites. Results of the spring program show that Tongue Point, Deep River, and Blind Slough sites show the greatest harvest potential in terms of low catch rates of nontargeted salmon species. The total chinook catch for all sites of 57 fish included only five upriver type. A total of 21 steelhead and 1,824 white sturgeon, most sublegal sized, were caught. The fall test fishery showed the lowest catch rates of nontargeted salmon at Tongue Point, Deep River, Blind Slough, Steamboat Slough, and Clifton Channel. The total catch consisted of nine chinook, 32 coho, one chum, five steelhead, 266 white sturgeon, and two green sturgeon.

When selecting hatchery stocks suitable for use in terminal fishing sites it is vital to consider potential impacts to native fish stocks. Most native naturally spawning salmonid populations in Oregon and Washington tributaries below Bonneville Dam are declining or depressed with some extinct. Also, economic value to fishers and communities, ecological impacts, and biological factors need to be considered.

Availability of hatchery production and the role of hatchery production relating to harvest allocation obligations is a very important factor in development of successful terminal fisheries. Use of new production will optimize present hatchery capability while keeping within the aggregate annual smolt production ceiling of 197.4 million for the Columbia River basin established by the National Marine Fisheries Service. 
Cost associated with implementation of a large scale rearing and release program of 370 net pens at seven new sites and Youngs Bay Expansion is estimated to be $\$ 3,536,000$ for capital expenditure and about $\$ 3,000,000$ annually for operation and maintenance. Estimated smolt production of 57.0 million comprised of a mix of spring chinook, fall chinook, and coho could be realized assuming unrestricted availability. Cost estimates were generated for the development of a business plan for lower Columbia River tèrminal fisheries produced by SFA.

To measure the effect of shifting various levels of lower Columbia River mainstem commercial fisheries to terminal areas, a harvest impact model can be applied to demonstrate the savings in escapement for upriver salmon runs with various harvest reduction scenarios. In the case of endangered Snake River wild fall chinook an increase of $41 \%$ in wild escapement can be realized with a $100 \%$ reduction in nonIndian commercial harvest rates, no reallocation of harvest to Indian fisheries, and assuming the optimum conversion rates at dams. The intent of terminal fisheries is to provide sustainable harvest opportunities by bolstering harvest of hatchery stocks while reducing interceptions of weaker ones. 


\section{INTRODUCTION}

\section{HISTORY}

Columbia River terminal fisheries have been conducted in Youngs Bay, Oregon, since the early 1960's when coho salmon were first reared and released in adjacent tributaries, and gill net fisheries occurred in subsequent fall seasons as adults returned through the bay to Klaskanine Hatchery. The Clatsop County Economic Development Council (CEDC) Fishery Project established smolt and hatchery rearing sites at Tucker Creek and South Fork Klaskanine River. These sites augmented production from the Oregon Department of Fish and Wildlife (ODFW) North Fork Klaskanine River Hatchery. In 1977, CEDC began production of chinook and chum salmon into Youngs Bay to expand the terminal fishery.

In the years 1980-82 the Washington Department of Fish and Wildlife (WDFW) conducted fall commercial gillnet fisheries at five sites: Grays Bay, SkamokawaSteamboat Slough, Elochoman Slough, Cowlitz River, and Camas Slough. The intent was to selectively harvest abundant hatchery chinook and coho stocks off the main channel. In 1983, 1987 and 1988 a similarly designed fishery was conducted by ODFW at the mouth of Big Creek. Seasons and harvests from all terminal fisheries in recent years are shown on Table 1.

In 1987, CEDC began net pen rearing in Youngs Bay in order to expand rearing capacity, augment production, improve local imprinting, and enhance adult salmon returns to Youngs Bay. The first experimental net pens were deployed approximately 0.5 miles above the old Youngs Bay Bridge near. Tide Point. Eight pens were initially deployed at this site. As of February 1995, 72 net pens had been deployed, more than double the number in 1992.

Total CEDC and ODFW releases of coho salmon into Youngs Bay grew from 1.18 million smolts in 1977 to 5.06 million smolts in 1993 (Table 2). Fall chinook releases peaked at 7.34 million in 1986 and declined to zero in 1993 (Table 3). Experimental production of spring chinook was initiated with the release of smolts and fingerlings for 1988-91 broods. Beginning with 1992 broods, only full-term smolts were released; that year reaching a peak of 411,300 fish (Table 4).

Fall salmon harvests in Youngs Bay. averaged 349,000 pounds from 1979 to 1993 (Table 1). The 1993 fall catch was 114,800 pounds, including chinook and coho. A spring terminal fishery has recently been established during April and May with returns from experimental releases of spring chinook. Spring fishery harvests have been small to date as the first experimental releases began returning to Youngs Bay. A total of 100 to 300 Oregon and Washington gillnet vessels participate in Youngs Bay fisheries on an annual basis. 


\section{DESCRIPTION OF CURRENT 10-YEAR PROJECT}

In its 1993 Strategy For Salmon, the Northwest Power Planning Council recommended that terminal fishing sites be identified and developed to harvest abundant fish stocks while minimizing the incidental harvest of weak stocks. The Council called on the Bonneville Power Administration (BPA) to: "Fund a study to evaluate potential terminal fishery sites and opportunities. This study should include: general requirements for , developing those sites (e.g., construction of acclimation/release facilities for hatchery smolts so that adult salmon would return to the area for harvest); the potential number of harvesters that might be accommodated; type of gear to be used; and other relevant information needed to determine the feasibility and magnitude of the program".

Beginning in 1993, BPA initiated the Columbia River Terminal Fisheries Project, a 10year comprehensive program to investigate the feasibility of terminal fisheries in Youngs Bay and other sites in Oregon and Washington (BPA 1993). Terminal fisheries are being explored as a means to increase the sport and commercial harvest of hatchery fish while providing greater protection of weak wild salmon stocks. The project will be conducted in three distinct stages: an initial 2-year research stage to investigate potential sites, salmon stocks and methodologies; a second 3-year stage of expansion in Youngs Bay and introduction into areas of greatest potential as shown from initial stage; and a final 5-year phase of establishment of terminal fisheries at full capacity at all acceptable sites.

The goal of the project is to determine the feasibility of creating and expanding terminal, known stock fisheries in the Columbia River Basin to allow harvest of strong anadromous salmonid stocks while providing greater protection to depressed fish stocks. This goal is to be accomplished by addressing nine defined project objectives:

1. Survey and categorize potential terminal fishing sites in the Columbia River basin for basic physical characteristics (high, medium and low).

2. Determine the capability of the medium and high terminal fishing sites for rearing and acclimating anadromous fish species in net pens or other facilities.

3. Determine the capability of the medium and high terminal fishing sites to allow manageable and economically competetitive harvest of returning fish.

4. For the medium and high terminal fishing sites, determine the potential for harvest of target and non-target fish species.

5. Evaluate the suitability of various anadromous fish stocks for use in the medium and high terminal fishing sites. 
6. Determine the generic costs and logistics of a large-scale net pen rearing program (overwinter rearing and short-term acclimation) and estimate the variables for each of the medium and high terminal fishing sites.

7. Evaluate the effects of a large-scale net pen rearing program (overwinter rearing and short-term acclimation) for terminal fishing on hatchery production programs.

8. Determine the effects on upriver fish runs, escapements, and Zone 6 fisheries of shifting various levels of historical Zone 1-5 commercial fisheries to terminal sites.

9. Coordinate activities with ODFW, WDFW, CEDC, BPA, National Marine Fisheries Service (NMFS), and Salmon for All (SFA).

\section{DESCRIPTION OF WORK FOR CURRENT YEAR (1993-94)}

Under each of the above objectives a listing of tasks was to be accomplished during the period of October 1993 through November 1994 (Appendix 1). This report summarizes the activities and findings for each of those tasks. In general, those tasks included literature reviews, meetings with user groups, surveys of potential sites and rearing methodologies, initiation of fall and spring test fishing and water quality monitoring, evaluation of potential anadromous fish stocks, economic evaluation of terminal fishery impacts, and evaluation of overwintering spring chinook in Youngs Bay. 
Table 1. Columbia River terminal area commercial fishing seasons and landings, 1979 to $1993 .{ }^{1}$

\begin{tabular}{|c|c|c|c|c|c|c|c|c|c|c|c|c|c|}
\hline \multirow[b]{2}{*}{ Year } & \multirow[b]{2}{*}{ Fishery } & \multirow[b]{2}{*}{ Season } & \multirow[b]{2}{*}{ Days } & \multicolumn{2}{|c|}{ Chinook } & \multicolumn{2}{|c|}{ Coho } & \multicolumn{2}{|c|}{ Chum } & \multicolumn{2}{|c|}{ White Sturgeon } & \multicolumn{2}{|c|}{ Green Sturgeon } \\
\hline & & & & Pounds & Number & Pounds & Number & Pounds & Number & Pounds & Number & Pounds & Number \\
\hline 1979 & Youngs Bay & Aug 22-Oct 31 & 70 & 28,358 & 1,585 & 190,321 & 22,542 & 65 & 5 & 463 & 20 & 0 & 0 \\
\hline 1980 & $\begin{array}{l}\text { Youngs Bay } \\
\text { Grays Bay } \\
\text { Skamokawa } \\
\text { Elochoman } \\
\text { Cowlitz } \\
\text { Camas. }\end{array}$ & $\begin{array}{l}\text { Aug 24-Oct } 31 \\
\text { Aug 25-Sep } 12 \\
\text { Aug 25-Sep } 12 \\
\text { Aug 25-Sep } 12 \\
\text { Aug 25-Sep } 12 \\
\text { Aug 25-Sep } 12\end{array}$ & $\begin{array}{r}68 \\
7 \\
11 \\
11 \\
11 \\
11\end{array}$ & $\begin{array}{r}112,883 \\
335,806 \\
10,223 \\
86,979 \\
190,439 \\
66,196\end{array}$ & $\begin{array}{r}5,900 \\
16,502 \\
.555 \\
4,611 \\
10,224 \\
3,293\end{array}$ & $\begin{array}{r}103,422 \\
14,477 \\
5,308 \\
38,637 \\
48,210 \\
15,839\end{array}$ & $\begin{array}{r}12,526 \\
1,957 \\
681 \\
4,953 \\
6,603 \\
2,140\end{array}$ & $\begin{array}{r}468 \\
15 \\
0 \\
0 \\
0 \\
0\end{array}$ & $\begin{array}{r}39 \\
1 \\
0 \\
0 \\
0 \\
0\end{array}$ & $\begin{array}{r}1,952 \\
28,506 \\
77 \\
564 \\
370 \\
0\end{array}$ & $\begin{array}{r}70 \\
1,018 \\
3 \\
20 \\
13 \\
0\end{array}$ & $\begin{array}{r}412 \\
22,518 \\
0 \\
72 \\
84 \\
0\end{array}$ & $\begin{array}{r}16 \\
877 \\
0 \\
3 \\
3 \\
0\end{array}$ \\
\hline 1981 & $\begin{array}{l}\text { Youngs Bay } \\
\text { Grays Bay } \\
\text { Skamokawa, } \\
\text { Elochoman } \\
\text { Cowlitz } \\
\text { Camas }\end{array}$ & $\begin{array}{l}\text { Aug } 17-\text { Nov } 12 \\
\text { Aug 24-Sep } 11 \\
\text { Aug 24-Sep } 11 \\
\text { Aug 24-Sep } 11 \\
\text { Aug 24-Sep } 11 \\
\text { Aug } 31-\operatorname{Sep} 11\end{array}$ & $\begin{array}{r}87 \\
10 \\
10 \\
10 \\
10 \\
8\end{array}$ & $\begin{array}{r}113,279 \\
71,532 \\
56,063 \\
14,292 \\
215,210 \\
63,577\end{array}$ & $\begin{array}{r}4,688 \\
3,640 \\
3,019 \\
757 \\
10,821 \\
2,812\end{array}$ & $\begin{array}{r}67,197 \\
2,419 \\
3,358 \\
1,980 \\
18,517 \\
2,745\end{array}$ & $\begin{array}{r}8,110 \\
367 \\
442 \\
261 \\
2,764 \\
416\end{array}$ & $\begin{array}{r}2,402 \\
0 \\
0 \\
0 \\
11 \\
0\end{array}$ & $\begin{array}{r}181 \\
0 \\
0 \\
0 \\
1 \\
0\end{array}$ & $\begin{array}{r}1,245 \\
8,122 \\
96 \\
0 \\
504 \\
0\end{array}$ & $\begin{array}{r}46 \\
297 \\
\cdot 3 \\
0 \\
18 \\
0\end{array}$ & $\begin{array}{r}0 \\
2,020 \\
0 \\
0 \\
73 \\
0\end{array}$ & $\begin{array}{r}0 \\
78 \\
0 \\
0 \\
3 \\
0\end{array}$ \\
\hline 1982 & $\begin{array}{l}\text { Youngs Bayb } \\
\text { Camas }\end{array}$ & $\begin{array}{l}\text { Aug 16-Nov } 5 \\
\text { Sep 7-Sep } 10\end{array}$ & $\begin{array}{r}81 \\
3\end{array}$ & $\begin{array}{r}101,722 \\
30,378\end{array}$ & $\begin{array}{l}5,129 \\
1,604\end{array}$ & $\begin{array}{r}109,742 \\
13,988\end{array}$ & $\begin{array}{r}12,258 \\
2,077\end{array}$ & $\begin{array}{r}3,237 \\
0\end{array}$ & $\begin{array}{r}264 \\
0\end{array}$ & $\begin{array}{r}805 \\
26\end{array}$ & $\begin{array}{r}28 \\
1\end{array}$ & $\begin{array}{r}145 \\
0\end{array}$ & $\begin{array}{l}5 \\
0\end{array}$ \\
\hline 1983 & $\begin{array}{l}\text { Youngs Bay } \\
\text { Big Creek }\end{array}$ & $\begin{array}{l}\text { Aug } 22-\text { Oct } 18 \\
\text { Aug 29-Sep } 9\end{array}$ & $\begin{array}{r}57 \\
4\end{array}$ & $\begin{array}{l}66,002 \\
27,831\end{array}$ & $\begin{array}{l}3,553 \\
1,243\end{array}$ & $\begin{array}{r}23,484 \\
31\end{array}$ & $\begin{array}{r}3,550 \\
6\end{array}$ & $\begin{array}{r}60 \\
0\end{array}$ & $\begin{array}{l}5 \\
0\end{array}$ & $\begin{array}{l}470 \\
319\end{array}$ & $\begin{array}{l}17 \\
11\end{array}$ & $\begin{array}{r}18 \\
0\end{array}$ & $\begin{array}{l}1 \\
0\end{array}$ \\
\hline 1984 & Youngs Bay & Aug 20-Nov 2 & 74. & 74,179 & 3,696 & 374,768 & 40,620 & 2,212 & 177 & 563 & 21 & 87 & 3 \\
\hline 1985 & Youngs Bay & Aug 19-Nov 1 & 74 & 64,393 & 3,466 & 473,873 & 51,202 & 209 & 19 & 428 & 16 & 115 & 5 \\
\hline 1986 & Youngs Bayc & Aug 10-Nov 7 & 89 & 94,548 & 5,447 & 410,568 & 55,575 & 56 & 5 & 422 & 16 & 79 & 3 \\
\hline 1987 & $\begin{array}{l}\text { Youngs Bay } \\
\text { Big Creek }\end{array}$ & $\begin{array}{l}\text { Aug 9-Nov } 6 \\
\text { Aug 25-Sep } 11\end{array}$ & $\begin{array}{r}89 \\
9\end{array}$ & $\begin{array}{l}374,241 \\
272,871\end{array}$ & $\begin{array}{l}22,186 \\
14,734\end{array}$ & $\begin{array}{r}109,725 \\
5,591\end{array}$ & $\begin{array}{r}16,113 \\
746\end{array}$ & $\begin{array}{r}37 \\
0\end{array}$ & $\begin{array}{l}4 \\
0\end{array}$ & $\begin{array}{r}232 \\
80\end{array}$ & $\begin{array}{l}8 \\
3\end{array}$ & $\begin{array}{l}0 \\
0\end{array}$ & $\begin{array}{l}0 \\
0\end{array}$ \\
\hline 1988 & $\begin{array}{l}\text { Youngs Bay } \\
\text { Big Creek }\end{array}$ & $\begin{array}{l}\text { Aug } 21-\text { Oct } 31 \\
\text { Aug } 30-\operatorname{Sep} 8\end{array}$ & $\begin{array}{r}71 \\
4\end{array}$ & $\begin{array}{l}408,185 \\
213,904\end{array}$ & $\begin{array}{r}19,711 \\
9,216\end{array}$ & $\begin{array}{r}383,231 \\
1,287\end{array}$ & $\begin{array}{r}51,221 \\
172\end{array}$ & $\begin{array}{r}577 \\
0\end{array}$ & $\begin{array}{r}57 \\
0\end{array}$ & $\begin{array}{r}377 \\
42\end{array}$ & $\begin{array}{r}12 \\
1\end{array}$ & $\begin{array}{r}26 \\
0\end{array}$ & $\begin{array}{l}1 \\
0\end{array}$ \\
\hline
\end{tabular}


Table 1. continued

\begin{tabular}{|c|c|c|c|c|c|c|c|c|c|c|c|c|c|}
\hline \multirow[b]{2}{*}{ Year } & \multirow[b]{2}{*}{ Fishery } & \multirow[b]{2}{*}{ Season } & \multirow[b]{2}{*}{ Days } & \multicolumn{2}{|c|}{ Chinook } & \multicolumn{2}{|c|}{ Coho } & \multicolumn{2}{|c|}{ Chum } & \multicolumn{2}{|c|}{ - White Sturgeon } & \multicolumn{2}{|c|}{ Green Sturgeon } \\
\hline & & & & Pounds & Number & Pounds & Number & Pounds & Number & Pounds & Number & Pounds & Number \\
\hline 1989 & Youngs Bay & Aug 20-Oct 31 & 72 & 133,283 & 6,665 & 178,385 & 28,066 & 30 & 2 & 623 & 20 & 345 & $\cdot 12$ \\
\hline 1990 & Youngs Bay & Aug 19-Oct 31 & 73 & 62,917 & 3,226 & 147,027 & 27,596 & 262 & 21 & 212 & 8 & 127 & 4 \\
\hline 1991 & Youngs Bay & Aug 18-Oct 31 & 74 & 39,100 & 2,241 & 528,197 & 82,123 & 130 & 13 & 751 & 31 & 453 & 23 \\
\hline 1992 & $\begin{array}{l}\text { Youngs Bay } \\
\text { Youngs Bay }\end{array}$ & $\begin{array}{l}\text { Apr 27-May } 26 \\
\text { Aug 16-Oct } 31\end{array}$ & $\begin{array}{r}9 \\
76\end{array}$ & $\begin{array}{r}3,348 \\
23,419\end{array}$ & $\begin{array}{r}296 \\
1,553\end{array}$ & $\begin{array}{r}0 \\
93,264\end{array}$ & $\begin{array}{r}0 \\
19,552\end{array}$ & $\begin{array}{r}0 \\
382\end{array}$ & $\begin{array}{r}0 \\
46\end{array}$ & $\begin{array}{l}381 \\
927\end{array}$ & $\begin{array}{l}10 \\
31\end{array}$ & $\begin{array}{r}0 \\
117\end{array}$ & $\begin{array}{l}0 \\
6\end{array}$ \\
\hline 1993 & $\begin{array}{l}\text { Youngs Bay } \\
\text { Youngs Bay }\end{array}$ & $\begin{array}{l}\text { Apr 26-May } 26 \\
\text { Aug 22-Oct } 31\end{array}$ & $\begin{array}{r}9 \\
70\end{array}$ & $\begin{array}{r}12,780 \\
5,121\end{array}$ & $\begin{array}{l}851 \\
365\end{array}$ & $\begin{array}{r}0 \\
109,719\end{array}$ & $\begin{array}{r}0 \\
15,458\end{array}$ & $\begin{array}{r}0 \\
39\end{array}$ & $\begin{array}{l}0 \\
4\end{array}$ & $\begin{array}{l}974 \\
385\end{array}$ & $\begin{array}{l}32 \\
17\end{array}$ & $\begin{array}{r}0 \\
30\end{array}$ & $\begin{array}{l}0 \\
1\end{array}$ \\
\hline
\end{tabular}

1 Source: WDFW \& ODFW 1994

amergency extension of last week. Scheduled to close November 6.

- Emergency closure of fishery scheduled to close November 4.

c Emergency extension of last week. Scheduled to close October 31. 
Table 2. Releases of coho salmon into Youngs Bay; 1977 to $1993^{1}$.

\begin{tabular}{ccccc}
\hline $\begin{array}{c}\text { Year of } \\
\text { Release }\end{array}$ & \multicolumn{2}{c}{ Numbers of Released (Millions) } & $\begin{array}{c}\text { Year of } \\
\text { Adult Return }\end{array}$ \\
\cline { 2 - 5 } CEDC $^{2}$ & ODFW & Total & Adul \\
1977 & 0.05 & 1.13 & 1.18 & 1978 \\
1978 & 0.00 & 1.29 & 1.03 & 1979 \\
1979 & 0.00 & 1.24 & 1.24 & 1980 \\
1980 & 0.20 & 1.41 & 1.61 & 1981 \\
1981 & 0.09 & 2.49 & 2.58 & 1982 \\
1982 & 0.30 & 1.49 & 1.79 & 1983 \\
1983 & 0.32 & 2.18 & 2.50 & 1984 \\
1984 & 0.30 & 2.44 & 2.74 & 1985 \\
1985 & 0.30 & 2.76 & 3.06 & 1986 \\
1986 & 0.40 & 1.93 & 2.33 & 1987 \\
1987 & 0.30 & 1.67 & 1.97 & 1988 \\
1988 & 0.20 & 1.61 & 1.75 & 1989 \\
1989 & $0.43(0.15)$ & 1.68 & 2.11 & 1990 \\
1990 & $1.56(0.78)$ & 1.39 & 2.95 & 1991 \\
1991 & $2.93(2.14)$ & 1.26 & 4.19 & 1992 \\
1992 & $3.08(2.42)$ & 1.02 & 4.10 & 1993 \\
1993 & $4.21(3.47)$ & 0.85 & 5.06 & 1994 \\
& & & & \\
\hline
\end{tabular}

1 Source: ODFW 1994

${ }^{2}$ Net pen releases are shown in parenthesis and included in CEDC total. 
Table 3. Releases of fall chinook into 'Youngs Bay, 1977 to $1993{ }^{1}$

\begin{tabular}{|c|c|c|c|c|c|c|}
\hline \multirow{3}{*}{$\begin{array}{r}\text { Year of } \\
\text { Release }\end{array}$} & \multicolumn{4}{|c|}{ Number of Released (Millions) } & \multirow{2}{*}{\multicolumn{2}{|c|}{ Year of Return ${ }^{2}$}} \\
\hline & \multicolumn{2}{|c|}{ CEDC } & \multirow{2}{*}{$\frac{\text { ODFW }}{\text { Tule }}$} & \multirow[b]{2}{*}{ Total } & & \\
\hline & Tule & Rogue & & & Age 3 & Age 4 \\
\hline 1977 & 0.00 & 0.000 & 7.19 & 7.19 & 1979 & 1980 \\
\hline 1978 & 0.85 & 0.000 & 4.29 & 5.14 & 1980 & 1981 \\
\hline 1979 & 1.40 & 0.000 & 5.57 & 6.97 & 1981 & 1982 \\
\hline 1980 & 2.02 & 0.000 & 3.55 & 5.57 & 1982 & 1983 \\
\hline 1981 & 3.16 & 0.000 & 3.94 & 7.10 & 1983 & 1984 \\
\hline 1982 & 2.74 & 0.000 & 3.31 & 6.05 & 1984 & 1985 \\
\hline 1983 & 2.48 & 0.050 & 3.51 & 6.04 & 1985 & 1986 \\
\hline 1984 & 2.87 & 0.013 & 4.08 & 6.96 & 1986 & 1987 \\
\hline 1985 & 3.00 & 0.082 & 1.60 & 4.68 & 1987 & 1988 \\
\hline 1986 & 3.01 & 0.251 & 4.08 & 7.34 & 1988 & 1989 \\
\hline 1987 & 1.34 & 0.020 & 3.76 & 5.12 & 1989 & 1990 \\
\hline 1988 & 3.08 & 0.080 & 3.76 & 6.92 & 1990 & 1991 \\
\hline 1989 & 0.02 & 0.097 & 4.03 & 4.15 & 1991 & 1992 \\
\hline 1990 & 0.00 & 0.128 & 0.00 & 0.13 & 1992 & 1993 \\
\hline 1991 & 0.00 & 0.000 & 0.00 & 0.00 & -- & -- \\
\hline 1992 & 0.00 & 0.056 & 0.00 & 0.06 & 1994 & 1995 \\
\hline 1993 & 0.00 & 0.000 & 0.00 & 0.00 & -- & -- \\
\hline
\end{tabular}

1 Source: ODFW 1994

2 The majority return as Age 3 and 4 adults.

Table 4. Releases of Willamette stock spring chinook into Youngs Bay, 1989 to 1993.

\begin{tabular}{rrrrrr}
\hline $\begin{array}{r}\text { Year of } \\
\text { Release }\end{array}$ & Fingerlings & Smolts & Total & \multicolumn{2}{c}{ Year of return } \\
\hline & & & & & Age 4 \\
1989 & 263,300 & 54,300 & 317,600 & 1992 & Age 5 \\
1990 & 370,700 & 0 & 370,700 & 1993 & 1994 \\
1991 & 330,500 & 31,700 & 362,200 & 1994 & 1995 \\
1992 & 376,300 & 0 & 376,300 & 1995 & 1996 \\
1993 & 0 & 411,300 & 411,300 & 1996 & 1997 \\
\hline
\end{tabular}




\section{CHAPTER 1. SURVEY AND CATEGORIZATION OF POTENTIAL TERMINAL FISHERY SITES}

\section{A. Selection of Terminal Fisheries Sites}

\section{INTRODUCTION}

As the first step in establishing the terminal fishery program, rearing and harvest sites were chosen and evaluated. With the help of historic data from previous test and commercial fisheries, and meetings with SFA fishermen, a total working list was established of sites that had some potential. Total budget and manpower restrictions provided the working limits of the project: four sites for each state. This total of the best potential sites would provide the locations that would be evaluated in the immediate future.

\section{METHODS}

A total list of potential sites was established. The steps utilized in reducing this total involved ranking each site according to its rearing and harvest potential. For five rearing and five harvest criteria the site received a rating of 0 through 3 according to its level of potential, thus allowing a maximum rating of 30 for a site considered to have perfect potential. If a site received a 0 rating in any criteria it was eliminated from consideration.

Future experience in these sites may be cause for re-evaluation of its ranking. Following are the ranking criteria used in considering all sites:

\section{Rearing Site Selection Criteria}

1. Selected sites should have sufficient area and depth characteristics to accommodate a minimum number of rearing units to support an economically viable fishery. To determine "sufficient area and depth" the type of rearing unit, rearing strategy, species reared, and minimum production level needs to be evaluated. The minimum smolt production level will be dependent on the number of harvestable adults returning to support an economically viable fishery. The following examples illustrate a method of calculating minimum rearing space: 


\section{Example A: Spring Chinook}

Assume that the minimum value of a viable fishery is $\$ 75,000$ at the fisherman level. For spring chinook, assuming 15 pounds/fish and $\$ 2.50$ per pound, each fish would be worth $\$ 37.50$. A total catch of 2,000 spring chinook adults would be needed to create a value of $\$ 75,000$ for the fishery. The number of smolts needed to produce a catch of 2,000 adults at a $100 \%$ harvest rate is 200,000 smolts, assuming a one percent return rate. To rear 200,000 smolts with floating net pens $\left(20^{\prime} \times 20^{\prime} \times 8^{\prime}\right)$ that would accommodate 28,800 smolts at 12 fish per pound $(2,400 \mathrm{lbs}$. of smolts, where rearing density of $0.75 \mathrm{lbs} / \mathrm{cu} . \mathrm{ft}$. is assumed based on Youngs Bay experience) would require seven pens under an overwinter rearing plan. With a two-week acclimation plan only two pens would be necessary assuming that four groups of 28,800 smolts could be reared and released at each pen. If pens with a depth of 8 ' are used, a minimum depth of 11 ' would be required at extreme low water (Oregon Department of Environmental Quality (ODEQ) guideline). Surface area for each net pen is approximately 480 square feet when allowing for a two foot walkway. For seven pens, 3,360 square feet is the minimum area needed.

\section{Example B: Coho}

Assume that the minimum value of a viable fishery is $\$ 75,000$ at the fisherman level. For coho at seven pounds per fish and $\$ 1.00$ per pound, each fish would be worth $\$ 7.00$. About 10,700 adult coho would be required to generate $\$ 75,000$. The number of smolts needed to generate 10,700 adults at a $100 \%$ harvest rate is $1,070,000$ smolts (using a one percent return rate). Rearing requirements for $1,070,000$ smolts using floating net pens $\left(20^{\prime} \times 20^{\prime} \times 8^{\prime}\right)$ that would accommodate 28,800 smolts at 12 fish per pound $(2,400$ pounds of smolts, where rearing density of $0.75 \mathrm{lbs} / \mathrm{cu}$.ft. is assumed based on Youngs Bay experience) is about 37 net pens under an overwintering plan. With a two-week acclimation plan about ten net pens would be needed. With an $8^{\prime}$ deep pen a minimum depth of 11 ' is required at extreme low water (ODEQ guideline) given a surface area of 480 square feet per net pen (allowing for a two foot walkway), 17,760 square feet would be necessary for 37 net pens under an overwintering plan and 4,800 square feet would be required for ten net pens with a two-week acclimation plan.

2. Selected sites should have adequate flow and velocity characteristics to prevent degradation of water quality while providing natural food organisms. Water quality can be degraded as organic matter and nutrients are introduced during fish rearing activities. High concentrations of ammonia, nitrates, phosphates, and reduced levels of dissolved oxygen are known to adversely impact water quality. Adversé effects on 
water quality due to Puget Sound floating mariculture operations were most pronounced in areas of extremely limited flushing or water circulation (Weston 1986). Moreover, field studies have demonstrated little or no changes in water quality outside the floating culture structure in well-flushed areas (Gretchell 1988). In the case of Youngs Bay, tidal flushing activity is very high, with an estimated current velocity reaching as high as four knots. In areas with deeper water and faster currents, organic and inorganic wastes tend to be more dispersed, sedimentation remains oxidized, and invertebrate organisms have plentiful food supplies (Gretchell 1988).

The effect of tides in the Columbia River is a function of freshwater river discharge and proximity of the site to the river mouth. At Tongue Point, Oregon, a strong downstream current occurs on the ebb tide, followed by a slack water period, then an upstream current of lesser intensity and duration during the flood tide. The effect of the flood tide diminishes further upstream with a upstream current usually not detectable in the river section between river miles 45 and 65 .

3. Selected sites should provide protection from extreme weather and river conditions that would disrupt rearing operations. Extreme winter storms generate strong winds usually from the south to the southwest direction. Protection from wind and resulting wave action is desirable. Heavy rain and runoff is also associated with winter storms. Debris resulting the stormy conditions could also disrupt rearing operations. Site location should provide protection from strong south to southwest wind and waves and associated debris.

4. Selected sites should have land based access to rearing site and equipment with potential for development. Areas that are not land based (i.e. on an isolated island) or in a remote area inaccessible by road would require maintenance by water.

5. Selected sites should be located in areas with high probability for attracting returning adults. Sites influenced by a unique water source or-sources would be desirable over sites with little imprinting water available.

\section{Harvest Site Selection Criteria}

1. Selected sites should have sufficient area, depth, and proximity to attract local and nonlocal fishers. Sufficient area is difficult to quantify at a minimum level since with gear modifications, small areas and narrow sloughs with minimum depths for harvest of about ten feet (extreme low water level) would possibly attract both local and nonlocal fishers if the ex-vessel value of the fishery was high enough.

A site should have a local fleet which would operate even in the worst of times while being in close enough proximity to attract nonlocal fishermen who could trailer or motor 
in (by water) during peak periods.

Presently, an area like Youngs Bay best fits the requirements of depth, area, and proximity to attract local and nonlocal fishers since traditional gear (with only minor modifications) and vessels are employed. Peak daily deliveries in excess of 90 (based on fish tickets) have been recorded since 1985 .

2. Selected sites should be accessible and accommodating to fishing vessels and fish buyers. Moorage facilities for fishing vessels, and either land based or on the water sites for fish buyers, are necessary. Other desirable facilities would include fuel, close proximity to roads, parking, boat ramps, and hoist. If these facilities are not already in place, possibilities should exist for future installations.

3. Selected sites should minimize the interaction between commercial fishers and other river user groups. Locations with commercial traffic (i.e. tug, log raft, ferry) or recreational traffic (i.e. sport fishers, sail boaters and boarders, ski boaters, and recreational cruisers) should be avoided. Also, areas where both sport fisheries and commercial fisheries can occur simultaneously or adjacent to each other should be carefully evaluated.

4. Selected sites should have definable boundaries for enforcement and biological monitoring activities. Easily recognizable markers associated with permanent landmarks are preferred.

5. Selected sifes should maximize the harvest of target fish stocks in the terminal area while minimizing the impacts on nontarget species and sensitive fish stocks. Impacts to species listed under the Endangered Species Act (ESA) must be addressed and estimated each year as part of the consultation process. If a "no jeopardy opinion" is granted, fisheries can then operate within the specified guidelines.

The 1993 estimated impact on upriver spring chinook in the Youngs Bay spring commercial fishery was 12 mortalities with only a single Snake River wild spring chinook included (LeFleur 1993). Spring terminal fisheries with impacts approximating that observed in Youngs Bay are desirable.

Impact on Snake River wild fall chinook in the Youngs Bay fall commercial fisheries can be calculated using the data generated in the WDFW Fall Chinook Predictor Data Base. An estimated 406 upriver brights were caught in 1992 of which four were Snake River wild, which equates to two Snake River bright wild escapement at Lower Granite Dam. An estimated two upriver brights were caught in 1993 of which none were estimated to be wild Snake River brights (calculated value is 0.026 , a small fraction of one wild Snake River bright). Impacts of this magnitude are to be expected for each selected terminal fishery site during the fall time frame. 


\section{RESULTS AND DISCUSSION}

The review of lower Columbia River sites provided the following locations with terminal fisheries potential, listed by state and river mile:

\begin{tabular}{lrlr} 
Washington & RM & & Oregon \\
\hline Deep River/Grays Bay & 22 & Baker Bay & 5 \\
Steamboat Slough & 34 & & Skipanon Waterway \\
Elochoman River & 36 & Youngs Bay Expansion & 11 \\
Cathlamet Channel & 40 & - Tongue Point Basin & 12 \\
Coal Creek Slough & 56 & Svensen Island & 18 \\
Fisher Island Slough & 60 & Big Creek & 23 \\
Cowlitz River & 68 & Blind Slough & 27 \\
Carrolls Channel & 70 & Clifton Channel & 28 \\
Martin Slough & 80 & . Coffee Pot Island & 36 \\
Lewis River & 87 & Westport Slough & 43 \\
Lake River & 89 & . Wallace Island & 44 \\
Camas Slough & 120 & Bradbury Slough & 49 \\
& & . Wahkeena Pond & 55 \\
& & & 135
\end{tabular}

\section{Site Ranking}

Ranking of potential sites is based on rearing criteria $(\mathrm{RC})$ and harvest criteria $(\mathrm{HC})$, previous terminal and test fishery data, and comments from the SFA. Table 5 lists the results of the site review, including a ranking of high, medium or low priority to indicate locations that should be given present or future consideration.

Nine sites were considered to have high priority, with an overall ranking sufficient for immediate consideration: three on the Washington and six on the Oregon shore. These sites are Grays Bay, Tongue Point basin, Big Creek, Blind Slough, Steamboat Slough, Svensen Island, Clifton Channel, Cathlamet Channel, and Wallace Slough.

Six sites had medium rankings, but with four of these having one or more criteria ranked 0 (failure), leaving two sites sufficient for possible future consideration, following testing and experience in the high ranked sites. These sites are the Lewis River and Bradbury Slough.

The remaining ranked sites had low priorities and would not be given further testing in the project: Fisher Slough, Cowlitz River, Carrolls Channel, Martin Slough, Lake River, Baker Bay, and Coffee Pot Island. Established production sites at Youngs Bay and Wahkeena Pond were not ranked. 
Of the nine high ranked sites, the three Washington sites and the four Oregon sites with highest potential were chosen for immediate study. The details of each are described as follows:

\section{Tongue Point (Oregon)}

RC 1. The Tongue Point site has the largest potential area and depth of all sites under consideration. Depths at potential pen area sites exceed the minimum. depth of 11 feet along all mooring piers. Presently, the northern most pier is dedicated for rearing purposes and can accommodate potentially as many pens as are in production in Youngs Bay.

RC 2. The Tongue Point basin should have flow and velocity characteristics to prevent degradation of water quality. The basin is affected primarily by tidal flushing with minor fresh water inflow from the John Day River and inflow from the South Channel of Prairie Channel.

RC 3. Tongue Point basin is sheltered from winter storm conditions and storm debris. The dedicated rearing site is especially protected since the easterly shore of Tongue Point is adjacent to and parallels the net pen location.

RC 4. Tongue Point rearing site access is excellent. Located in Astoria and within a mile of Highway 30 , the actual site is accessed by truck to the waters edge and, with pier repair, a vehicle could be driven onto the pier.

RC 5. The probability of attracting returning adults to Tongue Point is good, with uniqueness to the chemical properties of the rearing water influenced by the John Day River and Oregon tributaries draining into Prairie Channel and South Channel (Bear Creek, Ferris Creek, Big Creek, and Gnat Creek).

HC 1. Tongue Point possesses very favorable attributes. The majority of the basin depth is in excess of 30 feet, the potential fishing surface area is large enough to accommodate fishing power similar to Youngs Bay, and the basin is in close proximity to the major-concentrations of fishermen in the Astoria and Ilwaco vicinity. During past fall seasons, Tongue Point basin and South Channel have been sporadically fished.

HC 2. While moorage facilities and associated amenities such as fuel, parking and land based accessibility for fish buyers is not available within the basin perimeter, the proximity of Tongue Point to mooring basins, launching ramps, and on-water fish buyers in Astoria make Tongue Point very accommodating.

HC 3. Interactions between commercial fishers and other river users will occur 
in Tongue Point basin. During spring-fall, the John Day River launching ramp is very popular, with sturgeon fishers using the Tongue Point basin as a route to fishing locations and also as a fishing location. Other users infrequently use the basin at this time, including activities associated with the Job Corps Center and a US Army Corps of Engineers dock.

HC 4. Definable boundaries for Tongue Point Basin are distinct and easily recognizable. The "lower" boundary could extend from the Tongue Point light to the light at the north tip of Mott Island. The "upper" boundary could extend from John Day Point at the mouth of the John Day River to a buoy at the southeast tip of Lois Island.

HC 5. The potential for harvest of target fish stocks in the Tongue Point basin is good. Since the basin is not a closed-end water body and has South Channel as an inlet, the basin has some potential as a migration corridor for salmon stocks destined for areas upstream. Most likely stocks are those destined for Oregon tributaries that drain into Prairie Channel: Bear, Big, Gnat and Ferris creeks are examples. Presently, most salmonid populations are hatchery produced in tributaries. Potential impact to stocks listed under the ESA need to be defined with results from test fishing during anticipated spring and fall harvest windows. Abundance of white sturgeon in the Tongue Point basin is believed to be high, especially during the summer and fall months.

\section{Deep River/Grays Bay (Washington)}

RC 1. Grays Bay appears to have the area and depth required to accommodate a modest number of rearing units. There is currently one rearing facility in Deep River upstream of the Highway 4 bridge with 50,000 fall chinook salmon. Most ideal location is the landing in the lower stretches of Deep River at "Tiny's", where pilings and docks are available.

RC 2. Grays Bay would likely meet the flow and velocity requirements by a combination of flushing tidal action and freshwater inflow from Deep River, Grays River, and Seal Slough. Grazing operations in the Grays Bay bottomlands would be a source of nitrogen and phosphate pollution that could impact this site.

RC 3. A rearing site in Deep River would provide good protection from most extreme weather conditions. Though temperature may be a factor in the late summer/fall time periods; rearing practices could avoid the warmer times.

RC 4. Deep River, Grays River, and Seal Slough have roadways associated 
with their banks that would allow installation, stocking, feeding, and maintenance of rearing net pens. Access to the water from the roads would require perimission from private landowners.

RC 5. Grays Bay has the flow and chemical distinction necessary to attract returning adults back to the area.

HC 1. Grays Bay possesses the area and proximity qualities, but includes many shallow areas. The bay could support a modest number of gill net boats. Washington State law denies commercial net fishing for salmon in Grays Bay, Grays River, and Deep River from December 1 through August 31. These laws would need modification before terminal fisheries could be conducted.

HC 2. Grays Bay is accessible to fishing vessels, but the numerous shallows detract from its' accommodating qualities. The bay is relatively close to the ports of Chinook and Ilwaco, Washington and Astoria and Warrenton, Oregon. A private boat launch on Deep River would likely be inaccessible to gill net boats due to its' small size. There is a buying site on Deep River at "Tiny's". Other land based buyers could locate at the marinas. The bay would be amenable to operating a buying boat. "Tiny's" docks are also used as mooring sites.

HC 3. Interaction between commercial fishers and sport fishers might occur in the Grays Bay area. The mouth of Grays Bay area is a popular sturgeon fishing site for Washington and Oregon anglers during spring, summer and fall. Many Washington anglers use the Deep River ramp.

HC 4. Grays Bay is bounded by the Washington shore on three sides and the Columbia River on the fourth. Several markers, buoys and land points make the boundaries easy to define.

HC 5. The Grays Bay watershed supports runs of fall chinook, coho, chum, and winter steelhead. A WDFW hatchery exists on the West Fork Grays River. Abundance of commercially legal white and green sturgeon in Grays Bay is relatively high during the summer and fall. Potential impacts to. ESA stocks were documented during 1980 and 1981 terminal fisheries. Chinook salmon harvest during the 1980 and 1981 fisheries was primarily composed of lower river hatchery stocks (1980; $57 \%$ lower river stocks, $1981 ; 62.3 \%$ lower river stocks). The harvest of Bonneville Pool Hatchery (39 and 33\% for 1980 and 1981, respectively) and Upriver Bright stock (four percent both years) was attributed to fishers netting outside of the terminal area in the mainstem Columbia-River. Maximizing the catch of target species/stocks while minimizing the impacts to nontarget stocks/species would require fall fishing prior to the arrival of chum and winter steelhead, or spring fishing after winter steelhead have moved out of 
the bay and into the tributaries.

\section{Skamokawa Creek/Steamboat Slough (Washington)}

RC 1. The Skamokawa Creek/Steamboat Slough area is constrained but appears to meet the area and depth requirements to accommodate a modest number of net pens. Dan Silverman's dock at his buying site near Skamokawa could accommodate pens, as might the piling with easy shore access at the upriver end of Steamboat Slough.

RC 2. The Skamokawa Creek/Steamboat Slough appears to receive adequate flow, velocity, and tidal action to prevent water quality degradation.

RC 3. The Skamokawa Creek/Steamboat Slough site would afford good - protection from most extreme weather conditions. Access to the rearing pens might be restricted during high flows or flood events.

RC 4. The Skamokawa Creek/Steamboat Slough area has good road access along Steamboat Slough that would allow installation, stocking, feeding, and maintenance of rearing net pens.

RC 5. The Skamokawa Creek/Steamboat-Slough has sufficient flow to attract returning adults, but the slough may lack distinctive chemical characteristics for precise homing.

HC 1. The Skamokawa Creek/Steamboat Slough area is constrained and may lack the area required to attract nonlocal fishers. Washington State law denies commercial net fishing for salmon in Elochoman River, Elochoman Slough, and Skamokawa Slough from December 1 through August 31; a law that would need to be changed before terminal fisheries are conducted during spring or early fall.

HC 2. The Skamokawa Creek/Steamboat Slough area appears accessible to fishermen and buyers. There are fishermen residing in the vicinity. The area is close to the Cathlamet boat basin which accommodates commercial gill net boat launches. There is a buying site on Steamboat Slough at "Silvermans". Land based buyers could locate at the boat basin. The area would be amenable to the operating a buying boat. Local gill net moorages are at Cathlamet, Skamokawa, Clifton and on Puget Island,

HC 3. Limited interactions between commercial fishers and other river users might occur in the Skamokawa/Steamboat Slough area. These are commercial fishing communities where locals are accustomed to these activities. This area 
attracts sturgeon, steelhead and cutthroat fishers during restricted periods of time.

HC 4. The Skamokawa Creek/Steamboat Slough area is bounded on the north by the Washington bank (Julia Butler Hansen Columbian White Tailed Deer Refuge), on the south by Price Island, and the eastern and western boundaries are adjacent to the Columbia River. Boundaries adjacent to the Columbia River would need to be defined to delineate open and closed waters, with established lights and land markers being used in historical fisheries. .

HC 5. Skamokawa Creek supports runs of fall chinook and coho salmon and winter steelhead trout. Potential impacts to ESA stocks were documented during the 1980 and 1981 terminal fisheries. The chinook salmon harvest during those fisheries was comprised of at least $70 \%$ lower river stocks. The 1980 harvest included about two percent upriver bright stock ( 89 fish), and the 1981 harvest did not include an upriver bright component. The remaining harvest was Bonneville Pool hatchery stocks. Maximizing the catch of target species, while not impacting the non target species and stocks would require timing fall fisheries after the peak passage of ESA stocks and prior to the peak arrival of winter steelhead trout. Spring fisheries would need to be timed after the peak passage of ESA stocks and prior to the peak arrival of summer steelhead trout.

\section{Blind Slough (Oregon)}

RC 1. Blind Slough meets the minimum depth criteria of at least 11 feet throughout most of the slough where net pens could be placed. Although the maximum number of pens potentially could approach the magnitude estimated for Tongue Point based on available area, the realistic maximum will probably depend on flow and velocity limitations.

RC'2. Flow and velocity characteristics in Blind Slough are dictated by runoff from Gnat Creek and tidal action. Flushing action will be variable depending on rainfall and freshets during the late fall through spring period and at its lowest during the summer through early fall period.

RC 3. Protection against weather and storm is very good since Blind Slough is narrow and isolated from the mainstem of the Columbia River. Storm debris should also not be a problem. Also rearing pens are accessible at all water stages.

RC 4. Access to rearing sites is land based via paved county roads built on dikes paralleling the slough. Potential for development is good and need to 
include additional piling, floats, and perhaps a dock to fully utilize the site's potential.

RC 5. Blind Slough is an area with a high probability of attracting returning adults since Gnat Creek is the sole tributary draining into the slough.

HC 1. Blind Slough can accommodate only a limited number of fishermen because of its narrow, confined channel. Because of the lack of strong currents however, Blind Slough could potentially accommodate modified or stationary gear at almost any stage of tide throughout its length. Because of the unique requirements for harvest, this site may not attract nonlocal fishermen.

HC 2. Blind Slough is home port to a small group of fishers with float houses utilized as moorages. Other moorages in close proximity are located at Svensen Island and Woody Island on the Oregon side, while Washington boats are a greater distance away at Skamokawa and Altoona/Pillar Rock. A marginally useable launch ramp presently exists within Blind Slough. Other amenities such as fuel, parking, and related conveniences presently are lacking but are future possibilities.

HC 3. Interactions with other user groups is presently limited to wildlife watchers. Commercial traffic and recreational traffic is rare. Sport fishing activities are presently focussed on warm water species and usually pursued in backwater or off-slough areas.

HC 4. Blind Slough has easily definable boundaries that can be used for delineating open areas.

HC 5. Blind Slough has very good potential to maximize harvest target stocks because of the confined harvest area. The likelihood of nonlocal stocks of salmonids to wander into Blind Slough should be slight since flow and velocity characteristics along with the unique water quality should not be attractive to nonlocal adult salmonids. Local stocks of salmonids are limited to those utilizing limited spawning habitat in Gnat Creek and small tributaries. Sturgeon by-catch would appear to be low when compared to sites adjacent to the mainstem channel. An exploratory test fishery conducted in Blind Slough during September and October showed the presence of coho, fall chinook, steelhead and cutthroat trout, however no estimate of magnitude or origin was attempted. 


\section{Clifton Channel (Oregon)}

RC 1. Clifton Channel has the area and depth to meet the minimum criteria. Piling structure at the Clifton fish station and additional potential piling sites in the vicinity are available to secure net pens.

RC 2. Flow and velocity characteristics at Clifton Channel are a function of both tidal and mainstem freshwater discharge. At river mile 37 the influence of the flowing tide is diminished with maximum flushing occurring during ebb tide. Proximity of the Clifton site to the main channel should enhance flushing action.

RC 3. Protection from storm and resulting debris during winter and spring is good since the potential site is shielded from southwest storm driven wind. The potential sites is however exposed to northwesterly winds which at times can create moderate wind chop.

RC 4. Land based access to the potential sites is good since a paved county road from Highway 30 terminates in Clifton.

RC 5. The potential rearing site at Clifton is located downstream about $1 / 2$ miles from the mouth of Hunt Creek at Bradwood. Hunt Creek's plume should follow the shoreline to provide imprinting water for the smolts reared in the net pens.

HC 1. Clifton Channel is an established fishing area with harvest opportunities at all stages of tidal and river flows. A small local fleet operates at the fish station while nonlocal fishermen are in close proximity at Woody Island, Skamokawa, Cathlamet and Westport.

HC 2. The fish station at Clifton is privately owned and can potentially provide access for fish buying and boat moorage. Hoist, road access and parking (potential) are desirable features. Water based fish buyers are in close proximity to boat launches at Cathlamet, Skamokawa, Aldrich Point and Westport.

HC 3. Commercial river traffic is limited to occasional tugs towing log rafts. Recreational users are infrequent users. of Clifton Channel except for sport fishermen during spring months when the mainstem spring chinook season is open.

HC 4. Definable boundaries should be easy to establish using existing navigational markers and signs that are visible across the channel.

HC 5. The potential of Clifton Channel to maximize the harvest of target fish 
stocks while minimizing the impact on nontarget and sensitive fish stocks needs to be carefully assessed by test fishing. Harvest and impact levels similar to Youngs Bay may nót be attainable unless a harvest window can be identified. Since Clifton channel is open ended at both ends, it potentially is a migration. route for some upriver stocks of fish. Though white sturgeon are present in moderate numbers in Clifton Channel throughout the year, they should not present a problem.

\section{Cathlamet Channel (Washington)}

RC 1. Cathlamet Channel exceeds the minimum area and depth requirements to accommodate a maximum number of rearing pens. The channel has the port of Cathlamet, with associated docks and pilings, on the Washington shoreline. This includes the upstream entry into Elochoman Slough as a potential pen rearing location.

RC 2. Columbia River flow would provide adequate flow and velocity to maintain water quality. John Doumit (local teacher) rears and releases salmonids in the Cathlamet sewage treatment system (Bernie Creek). The port of Cathlamet is a potential source of nitrogen, phosphate, and turbidity that could impact this site.

RC 3. The Cathlamet Channel site would provide limited protection from most extreme weather conditions. The area could be susceptible to flood conditions that would limit access to net pens.

RC 4. The Cathlamet Channel area has fair road access for the installation, stocking, feeding, and maintenance of rearing net pens.

RC 5. Cathlamet Channel appears to have the flow and chemical distinction required to attract returning adults to the area. John Doumit rears and releases salmonids in Bernie Creek. Reportedly fish have returned to the area from his releases.

HC 1. Cathlamet Channel has the area, depth, and proximity to attract nonlocal anglers in numbers approaching those of Youngs Bay. Concentrations of fishers are located at Cathlamet, Skamokawa, Puget Island, and Clifton. Established drifts exist in the channel.

HC 2. Gathlamet Channel appears accessible to fishermen and buyers. There are fishermen residing in the vicinity. The area is adjacent to Cathlamet boat basin which accommodates commercial gill net boats. There is sufficient room 
for buyers to set up at the boat basin. The boat basin would provide some mooring. The area would be amenable to operating a buying boat.

HC 3. Cathlamet Channel area appears to be relatively free of controversial social and political issues. Cathlamet Channel is outside the main shipping lane, but does get log raft and barge traffic and is accessible to pleasure craft. Puget Island and the Nassa Point area (Washington shore) are popular spring chinook and summer steelhead sport fishing sites.

HC. 4. The Cathlamet Channel is bounded on the south by Puget Island and on the north by the Washington bank. The eastern and western ends of the channel are adjacent to the Columbia River. Boundaries adjacent to the Columbia River would need to be marked to delineate open and closed waters.

HC 5. Elochoman River and Skamokawa Creek are the closest watersheds with salmonid stocks. Both systems support runs of fall chinook and coho salmon, winter steelhead, and cutthroat and the Elochoman River also supports a run of summer steelhead. Other upriver salmonid stocks are likely to use the channel when migrating. Impacts to ESA stocks in Cathlamet Channel are undocumented. Maximizing salmon harvest while limiting impacts to nontarget stocks and species require knowledge of ESA stock presence during August through October and late April to May. Fall fisheries would need to be timed after the passage of ESA stocks and prior to the arrival of winter steelhead trout. . Spring fisheries would need to be timed after the passage of ESA stocks and prior to the arrival of summer steelhead trout.

\section{Wallace Slough (Oregon)}

RC 1. Potential rearing sites in Wallace Slough are located upstream from the mouth of the Clatskanie River along the Oregon shore. As with the Clifton site, a privately owned fish buying station provides the potential space for securing net pens. Sufficient depth and area for a modest number of pens is available. With additional pilings and pens, this site has the potential for more production on the downstream bank from the confluence of the Clatskanie River.

RC 2. Wallace Slough at the mouth of the Clatskanie River is located at about river mile 49. Tidal effect at the potential rearing site is minor at the flood stage and flushing action maximized during the ebb tidal stage. The long tidewater channel of the Clatskanie River dissipates the effect of the flood tide and accentuates the ebb effect, especially during high runoff periods.

RC 3. Wallace Slough is well protected from winter storms. The potential 
rearing site is in a protected area from all wind and with no open water nearby wave action is minimal. Heavy run off from the Clatskanie River should not affect the rearing site since the net pens will be located upstream of the confluence of the Clatskanie River.

RC 4. The Wallace fish station is accessible by paved road with equipment and related fish rearing supplies easily available.

RC 5. With the confluence of the Clatskanie River directly influencing the rearing area, there is a very high probability of attracting returning adults.

HC 1. Wallace Slough is an established area for commercial fishing with a limited number of fishermen using the drift during past winter, spring and sockeye seasons. A local group of fishermen numbering about 20 would be the primary participants in a fishery. The closest nonlocal fishermen are based at Cathlamet, Westport and Mayger. An additional harvest location along the Oregon shore and upstream of Wallace Island called the Patton Drift is a traditional fishing site with potential. A boat launch is located in Clatskanie, however use by commercial vessels is limited by depth and narrowness of the channel.

HC 2. Wallace fish station is currently úsed as a moorage and buying station during open commercial seasons and accommodates a local-fleet. Potential exists for water-based fish buyers and additional temporary moorage. Other desirable features include a hoist, parking, and proximity to roads. Fuel is not available, but is a future possibility.

HC 3. Interaction between commercial fishers and other users is minimal within Wallace Slough except for recreational traffic using the Clatskanie River enroute to the main channel of the Columbia River. Commercial traffic in the area is concentrated in the nearby main channel away from likely harvest areas.

HC 4. Definable boundaries for enforcement exist for Wallace Slough, however the area above Wallace Island along the Oregon shore (Patton Drift) is not as easily defined.

HC 5. Maximizing harvest of target stocks in Wallace Slough while minimizing impacts on nontarget and sensitive species will necessitate identifying harvest windows of opportunity. Nonlocal spring chinook, with their wandering migrational behavior, are known to use the Wallace area. Fall runs of chinook and coho destined for the Clatskanie River will be present, however impact of potential fall fishery on nonlocal fall chinook, coho, and steelhead are anticipated to be low. Test fishing will determine background impact levels for. 
nonlocal fish stocks. White sturgeon are abundant in the Wallace area and impacts will need evaluation.

\section{CONCLUSIONS AND RECOMMENDATIONS}

Site ranking evaluations determined that, for the initiation of the project, seven sites would be examined for pen rearing and harvest potentials: Tongue Point basin, Deep River/Grays Bay, Blind Slough, Steamboat Slough, Clifton Channel, Cathlamet Channel, and Wallace Slough. 
Table 5. Ranking of potential terminal fishery sites below Bonneville Dam.

\begin{tabular}{|c|c|c|c|c|c|c|c|c|c|c|c|c|}
\hline \multirow[b]{2}{*}{ Terminal Site } & \multicolumn{5}{|c|}{ Rearing Criteria } & \multicolumn{5}{|c|}{ Harvest Criteria } & \multirow{2}{*}{$\begin{array}{l}\text { Grand } \\
\text { Total }\end{array}$} & \multirow[b]{2}{*}{ Rank } \\
\hline & 1 & 2 & 3 & 4 & 5 & 1 & 2 & 3 & 4 & 5 & & \\
\hline \multicolumn{13}{|l|}{ WASHINGTON } \\
\hline Deep River/Grays Bay & 3 & 3 & 3 & 3 & 2 & 2 & 2 & 3 & 3 & 3 & 27 & $\mathrm{H}$ \\
\hline Steamboat Slough & 3 & 3 & 2 & 2 & 3 & 3 & 3 & 2 & 3 & 2 & 26 & $H$ \\
\hline Cathlamet Channel & 3 & -3 & 2 & 2 & 3 & 3 & 3 & 2 & 1 & 2 & 24 & $\mathrm{H}$ \\
\hline Coal Creek Slough & 2 & 0 & 2 & 1. & 2 & 1 & 1 & 2 & 2 & 3 & 16 & $<M$ \\
\hline Fisher Slough & 2 & 1 & 1 & 1 & 1 & 1 & 1 & 0 & 2 & 3 & 13 & $<\mathrm{L}$ \\
\hline Cowlitz River & 1 & 1 & 1 & 1 & 3 & 1 & 1 & 0 & 2 & 1 & 12 & $<\mathrm{L}$ \\
\hline Carrolls Channel & 3 & 2 & 1 & 0 & 1 & 2 & 2 & 1 & $1^{\prime}$ & 1 & 14 & $<\mathrm{L}$ \\
\hline Martin Slough & 2 & 2 & 2 & 0 & 1 & 2 & 2 & 0 & 2 & 2 & 15 & $<\mathrm{L}$ \\
\hline Lewis River & 1 & 2 & 2 & 1 & 3 & 1 & 2 & 1 & 2 & 1 & 16 & M \\
\hline Lake River & 1 & 2 & 2 & 2 & 2 & 1 & 1 & 1 & 2 & 1 & 15 & $\mathrm{~L}$ \\
\hline Camas Slough & 3 & 1 & 1 & 0 & 3 & 2 & 2 & 1 & 2 & 3 & 18 & $<M$ \\
\hline
\end{tabular}

OREGON

Youngs Bay Expansion

Skipanon Waterway

Baker Bay

Tongue Pt Basin

Svensen Island

Big Creek

Blind Slough

Clifton Channel

Coffee Pot Island

Westport Slough

Wallace Slough

Bradbury Slough

Wahkeena Pond

Not ranked and evaluated

$\begin{array}{rrrrrrrrrrrr}1 & 1 & 3 & 2 & 3 & 0 & 3 & 0 & 3 & 3 & 19 & <\mathrm{M} \\ 1 & 2 & 0 & 0 & 1 & 1 & 3 & 0 & 2 & 2 & 12 & <\mathrm{L} \\ 3 & 3 & 3 & 3 & 2 & 3 & 2 & 1 & 2 & 2 & 24 & \mathrm{H} \\ 1 & 3 & 3 & 2 & 3 & 1 & 2 & 2 & 2 & 2 & 21 & \mathrm{H} \\ 2 & 2 & 2 & 2 & 3 & 3 & 2 & 2 & 3 & 2 & 23 & \mathrm{H} \\ 2 & 3 & 3 & 3 & 3 & 2 & 2 & 3 & 3 & 3 & 27 & \mathrm{H} \\ 3 & 2 & 2 & 3 & 2 & 3 & 2 & 2 & 3 & 2 & 24 & \mathrm{H} \\ 1 & 2 & 1 & 0 & 1 & 1 & 0 & 2 & 3 & 1 & 12 & <\mathrm{L} \\ 1 & 2 & 3 & 2 & 3 & 1 & 1 & 0 & 3 & 3 & 19 & <\mathrm{M} \\ 3 & 2 & 2 & 3 & 3 & 2 & 2 & 2 & 3 & 2 & 24 & \mathrm{H} \\ 1 . & 2 & 2 & 1 & 1 & 1 & 2 & 2 & 2 & 16 & \mathrm{M}\end{array}$

H High priority sites.

M Medium priority sites.

L Low priority sites.

< Site conditions fail to meet one or more rank criteria.

* Site chosen for further study. 


\section{B. Describe and Map Physical Dimensions and Flow Characteristics.}

\section{INTRODUCTION}

Initial ranking of sites based on final criteria (Task I:B of Appendix 1 ) included subjective evaluation of physical and hydrological characteristics of each site. General depths and boundaries of each high priority site are determined using the Evergreen Pacific River Cruising Atlas: Columbia, Snake, Willamette, 1991.

On site measurements of depth at potential rearing and harvest locations, and water flow characteristics at and adjacent to potential rearing locations were recorded in the field (Table 6).

\section{METHODS}

During 1994 in the months of January and February, depth measurements were recorded using an Eagle Mach I Computer Graph recorded mounted on an ODFW 17' Boston Whaler. Depths were recorded along straight line transacts with special emphasis on the potential locations for net pens. Time and date were recorded to note tidal stage and depth corrections at extreme low tide.

Since water flow characteristics are a function of both total river discharge and tidal stage and height, the spring months when these variables are maximized were chosen to best reflect relative maximum water velocity at and adjacent to the potential rearing sites. Some measurements were taken during June and July, 1994, and at Cathlamet in December, 1994, and January, 1995, since the task couldn't be completed during the spring months. Total discharge at Bonneville Dam, the major source of river flow, averaged 188.9 kcfs during April 15 to May 14, 1994. The general direction of river flow at all sites was downstream at the ebb tide stage and upstream at the flood stage. Highest velocities are usually observed during the winter when maximum tidal differences and storm conditions coincide. Readings were taken using a Marsh McBirney Hydrostatic velocity meter (Model 201 D) suspended from a solid rod. A depth of five feet was chosen to standardize measurements.

Estimates of surface area were obtained from Bruce Fisher of the United States Geological Survey, Water Resources Division, using Global Information System (GIS) technology.

\section{RESULTS}

\section{Youngs Bay expansion}

Figure 2 shows Youngs Bay with the existing net pen location at Tide Point, proposed 
expansion area downstream of Tide Point and established harvest area. Depths correspond closely to those in the Cruising Atlas. At the proposed expansion area minimum depth is 12 feet at mean low tidal stage.

Water surface àrea of $4.46 \mathrm{sq}$. mi. is estimated for the existing harvest area of Youngs Bay. Maximum water velocity measurements at the current pen site were 1.20 knots at flood tide and $0.91 \mathrm{knots}$ during the ebb tide stage. Adjacent and toward the middle of the channel readings of 1.43 knots and 0.74 knots were recorded during flood and ebb tidal stages.

\section{Tongue Point Basin}

Figure 3 shows Tongue Point Basin with the proposed net pen location. The depths observed correspond closely with those displayed in the River Cruising Atlas when corrected for tidal stage. The potential net pen location is adjacent to the north side of the northerly most pier. Minimum depth measured along the 800 foot length of the pier when corrected to mean low water ranged from 13-15 feet. . Depth at high tide can be as deep as $\mathbf{2 3 - 2 5}$ feet. Surface area of Tongue Point site presently proposed is about 1.74 square miles.

Tongue Point Basin is an off-channel body of water bounded by Mott and Lois islands on the east and the Oregon mainland on the west. A shallow channel between the islands, South Channel, John Day River, and the opening to the main channel at Tongue Point are entry and exit locations for water flowing in or out of the basin. The hydrology in the basin is therefore complex. Velocity readings during maximum flood of about 0.66 and 1.04 knots at and adjacent to the proposed pen location and 0.28 (at) and 1.04 (adjacent) knots at maximum ebb indicate high flushing action at both tidal stages.

\section{Deep River}

Deep River, as it empties into Grays Bay, is shown in Figure 4. Depths were observed for the entire length of the lower river below the Highway 4 crossing, and were continued along the deeper western side of Grays Bay. They conformed quite closely with those indicated in the River Cruising Guide, ranging from less than ten feet to over 40 feet in the river. Grays Bay was deepest in the western channel-way, mostly in the 8-18 foot range, with shallows and flats over most of the eastern bay. At the proposed rearing site depths ranged from 15-24 feet at mean low tide.

The potential fishing area consists of all waters north of an east-west line drawn from Rocky Point, including the channels formed from the Deep River and Grays River drainages, and another channel running east from Rocky Point. Water surface area in lower Deep River, from below the Highway 4 crossing to the river mouth is about 0.3 
square miles. The fishable channels of upper Grays Bay cover about 1.02 square miles.

The proposed rearing site is in lower Deep River, as noted in Figure 4. Water flow at the site is influenced mostly by tidal flushing action, which can be considerable, with limited action from the Deep River drainage. Water velocities measured there were 0.57 knots at maximum flood and 0.53 at maximum ebb. In the mid-channel and adjacent to the rearing site maximum velocities are assumed to be similar.

\section{Blind Slough}

Figure 5 shows Blind Slough with the proposed pen site location and proposed boundaries for harvest. Depths observed correspond closely to the River Cruising Atlas and at the proposed pen site are 20 feet at mean low tide sfage. Water surface area of Blind Slough from a point about 0.5 mile above the concrete county bridge to mouth is about 0.29 square miles. An adjacent potential harvest area in Knappa Slough extending from the confluence with Prairie Channel downstream to the Knappa Dock at Warren Slough is approximately 0.27 square miles. Water velocity measurements taken at the proposed rearing location were 0.23 knots at maximum flood and 0.32 knots at maximum ebb. Measurements adjacent to the rearing site were not taken but assumed to be similar because of the narrow and uniform features of the slough. The lower velocity readings were expected since Gnat Creek is the only source of outflow in the slough.

\section{Steamboat Slough}

Steamboat Slough (Figure 6), is the channel way between Price Island and the mainland. Depths observed corresponded closely with those in the River Cruising Atlas, ranging from 14 to 23 feet for the entire length of the channel at mean low tide. At the proposed rearing site depths were about 15 feet at mean low tide. Water surface area is about 0.20 square miles for the full length of Steamboat Slough, including the short passage from the town of Skamokawa, Washington, to the mainstem Columbia River. Water velocities measured at the proposed net pen location were 0.33 knots at maximum flood and 0.69 knots at maximum ebb. The areas midchannel and adjacent to the rearing site are assumed to be similar.

\section{Clifton Channel}

Figure 7 shows Clifton Channel with proposed rearing location and approximate boundary for harvest. In general, depths measured correspond closely with the River Cruising Atlas. Depths measured at the proposed rearing location are at least 12 feet at mean low water stage. Water surface area is approximately 1.22 square miles in Clifton Channel bordering Tenasillahe Island from the upstream tip near Bradwood, 
Oregon to the westerly tip at Red Slough. Water velocities measured at the proposed net pen location were 0.24 knots at maximum flood and 1.55 knots at maximum ebb. In the area mid-channel and adjacent to the rearing site maximum velocities of 0.83 knots during the flood and 1.57 knots during the ebb were recorded.

\section{Cathlamet Channel}

Figure 8 shows Cathlamet Channel with the proposed net pen site, water measurement site and proposed fishing boundaries. Measured depths conformed closely with those shown in the River Cruising Atlas. This large channel way was generally quite deep, ranging from 20 to 40 feet in the main passageway to less than 15 feet in the shallows. Water surface area is approximately 4.04 square miles for the full length of Cathlamet Channel, between Puget Island and mainland Washington. Water velocities were. taken at the water quality measuring dock, just upriver from the Cathlamet, Washington, bridge on the mainland side of the channel. Maximum water velocity at flood tide was 0.30 knots at and 0.58 knots adjacent to the proposed net pen site. During ebb tidal stage maximum velocities of 0.68 at and 1.55 knots adjacent to the proposed site. As with some of the other larger channels, flow is quite complex, with influences from flows over some river flats and mainstem flows at the ends of the channel.

\section{Wallace Slough}

Figure 9 shows Wallace Slough with proposed net pen location and houndary for harvest. Measured depths again conformed generally to those in the River Cruising Atlas. At the proposed pen site depths are a minimum of 23 feet at mean low tidal stage. Water surface area is approximately 0.68 square miles in the slough bordering the south bank of Wallace Island. Maximum water velocities at the proposed pen site during flood tidal stage was only 0.12 knots while at ebb tide 1.03 knots was recorded. Adjacent and out toward the middle of the slough, 0.33 knots was observed during flood tide and 0.86 knots was observed at ebb tide. Water velocities and currents are complex when compared to a site such as Clifton Channel because the location of Wallace Slough at RM 49 is the furthest upriver of the high priority sites and the effect of the Clatskanie River acts as a buffer during flood tide. 
Table 6. Surface area of proposed harvest site (square miles), minimum depth at pen sites (feet), and maximum flood and ebb flows (knots) at terminal fishery sites, 1994.

\section{Surface Area Minimum Depth}

of Proposed at Pen Site at Maximum Flood Maximum Ebb

Site Harvest Site Mean Low Tide Pen Adjacent Pen Adjacent

\begin{tabular}{lllllll} 
Youngs Bay & 4.46 & 12 & 1.20 & 1.43 & 0.91 & 0.74 \\
Tongue Point & 1.74 & 14 & 0.66 & 1.03 & 0.28 & 1.04 \\
Deep River & 1.32 & 15 & 0.57 & & 0.53 & \\
& & & 15 & & & \\
Blind Slough & 0.29 & 20 & 0.23 & & 0.32 & \\
Steamboat Slough & 0.20 & 11 & 0.33 & & 0.69 & \\
Clifton Channel & 1.22 & 11 & 0.24 & 0.83 & 1.55 & 1.57 \\
Cathlamet Channel & 4.04 & 17 & 0.30 & 0.58 & 0.68 & 1.55 \\
Wallace Slough & 0.68 & 23 & 0.12 & 0.33 & 1.03 & 0.86 \\
\hline
\end{tabular}




\section{CHAPTER 2. CAPABILITY OF SITES FOR REARING ÂND ACCLIMATING ANADROMOUS SPECIES IN NET PENS}

\section{A. Water Quality Literature}

\section{INTRODUCTION}

As the terminal fisheries net pen rearing project has developed, two main goals have been identified as the central focus of monitoring the quality of the water in which fish will be placed. The first of these goals is to monitor the physicochemical parameters at each of the medium and high priority sites over time to determine if there are any obvious problems in the immediate areas of the fish rearing pens. The second of the goals is to begin a biomonitoring program which would use benthic macroinvertebrates as indicators of any adverse change in the surrounding natural environment as a result of the fish rearing operations.

\section{RESULTS OF LITERATURE SEARCH}

An extensive literature search was conducted for historical comparison of other collections and/or studies that may have been done at each of these sites. Few studies have been completed on the Columbia River that exhibited long-term sampling regimes and/or genus/species level identification of all organisms collected. These two caveats are of the utmost importance in the design and completion of a biomonitoring study.

In 1989 the Bi-State Water Quality Program (Tetra Tech,1993) initiated a baseline reconnaissance survey that included analysis of sediment chemistry, water column. chemistry, benthic macroinvertebrates and fish of the lower Columbia River. This study included a large number of sampling sites (54 sites) but only a single sampling period. This study did however, have many sites near all of the terminal areas that have been chosen as medium or high priority sites and the data they collected will be helpful for comparative purposes.

The NMFS has completed several different benthic macroinvertebrate surveys along various portions of the lower Columbia River (Durkin et al., 1981; Durkin \& Emmet, 1980; Durkin et al., 1982; Emmett et al., 1986; and McCabe et al., 1990). None of the surveys completed by NMFS had water quality as the main objective, but the benthic macroinvertebrate data will serve as a good comparative source for our future collections in the terminal areas.

The Columbia River Estuary Study Taskforce (CREST) and the Columbia River Estuary Data Development Program (CREDDP) have been involved in long-term studies of the 
ecology of the lower Columbia River's flora and fauna, as well as the economic impacts of human intervention of the lower Columbia River, Simenstad, 1984; Simenstad et al., 1984; Seaman, 1977; McIntire \& Amspoker, 1984; Holton et al., 1984; English et al., 1984.

The Bi-State Water Quality Program's Reconnaissance Survey was the only literature reference that gave any indication of water quality in or near any of the areas that are under consideration for the rearing of fish. They had some relatively low levels of zinc and aluminum that exceeded the maximum allowable levels permitted by the Environmental Protection Agency (EPA) at a collection site near the mouth of Deep River, WA, in Grays Bay. Near the upriver portion of Tenasillahe Island they found levels exceeding EPA regulations of furans and dioxins in both sediments and fish tissues and PCBs in fish tissues. Near Wallace Slough high levels of aluminum, iron, zinc and.lead were found in water column samples. Due to the small sample size there is no indication if these chemical levels are a chronic or an acute problem.

There were other sites that were found to be out of compliance with EPA regulations but most were near the large industrial areas; far removed from the proposed fish rearing sites. Most of their sites had low dissolved oxygen (DO) levels but the data is only representative of one sampling date at each site.

\section{DIRECTION FOR FUTURE WORK}

None of these studies has concentrated on the unique areas of the lower Columbia known as the terminal areas. Loosely defined, these are the backwater sloughs or tributaries of the lower Columbia that have a supply of water originating from outside of the Columbia River proper. This outside water supply from tributaries is necessary for the juvenile salmonids to imprint on before they journey to sea. Because of the unique nature of these particular sites, it would seem reasonable to expect different benthic macroinvertebrate assemblages from those found in the mainstem of the Columbia. Due to these differences, it will be a high-priority objective to make a baseline benthic macroinvertebrate collection before fish are placed in the rearing pens. Subsequent collections will be made after fish have been placed in the net pens to observe any changes in species composition of the benthic invertebrate fauna. The benthic collections will be made during different seasons of the year at the times of fish rearing. A thorough comparison will be made between the terminal areas and the mainstem areas that the above mentioned references have studied to further the current knowledge of the benthic fauna of the lower Columbia. 


\section{B. Water Quality Sampling}

\section{INTRODUCTION}

Though water quality monitoring is not required by either the Oregon Department of Environmental Quality (DEQ) or the Washington Department of Ecology (DOE) as part of the net pen permitting process, evaluation of each potential site would still benefit from the information provided by a water quality monitoring project. Over the time period of this report considerable time was spent reviewing appropriate water quality needs and sampling methodologies, acquisition of needed devices and instruments, and devising a long-term sampling plan. This sampling plan has been initiated as the second year of the project begins.

As indicated in the previous section, water quality sampling will consist of two directions: 1) continual monitoring of the physicochemical parameters to maintain constant surveillance of the water conditions of both the net pens in operation and of the proposed sites, and 2) biomonitoring of these sites to observe any long term harmful effects of the net pen rearing operations to the surrounding ecosystem.

\section{METHODS}

Sampling will be conducted at all seven high-priority sites (Tongue Point, Deep River, Blind Slough, Steamboat Slough, Clifton Channel, Cathlamet Channel, and Wallace Slough), and Youngs Bay. Physicochemical parameters will be monitored bi-monthly while biomonitoring will occur every third or fourth month.

Physicochemical parameters will be measured electrometrically using a Hydrolab Inc. multiparameter water testing devise. This computer automated apparatus, upon deployment, is capable of collecting data from several electrometric probes simultaneously. It will be pre-set to collect data for 24 hours, making repeated measurements at 30-minute intervals. Means and standard deviations of the means will be calculated for each of the following parameters: water temperature, $\mathrm{pH}$, specific conductance, dissolved oxygen, water turbidity, and reduction-oxidation potential . (redox).

A Ponar Grab Sampler is utilized for collecting biomonitoring samples. A standard sized bottom sample is collected at and adjacent to each net pen site, and an accounting of all microinvertebrate life made, by species. Over time comparisons are made to indicate any changes that may occur between sites; before, during and after net pen rearing at each site; and between life in areas beneath and adjacent to net pens. 


\section{Estimates of Homing and Straying Rates by Site and Fish Stock}

\section{INTRODUCTION}

The ability of salmon to home to their natal stream has been well documented in the literature. Olfaction is the primary sensory mechanism responsible for accurate homing of salmon once entering fresh water (Groat, C. and Margolis, L., 1991). The ability of juvenile salmon to imprint on odors experienced in their rearing environment and during their seaward migration as smolts determine their homing success on return as adults.

Precise homing of adult salmon to terminal rearing and release sites is of greatest importance to assure maximum harvest potential while at the same time minimizing the potential of strays interbreeding with genetically dissimilar populations. Information on homing from smolt releases at traditional hatchery sites that have provided terminal harvest opportunity is available; however, homing data from net pen acclimation and release experiments are just now being evaluated.

To accurately estimate homing and straying rates is a difficult task. The ability of salmon to home back to a specific rearing and release location such as a net pen site will be dependent on the species and stock proposed, history of the proposed stock in the lower Columbia River area, and degree of uniqueness to the water during rearing and release times. Monitoring of homing and straying of adults from net pen-reared smolts will require annual evaluation.and analysis to determine if expected rates are attained within acceptable limits.

\section{METHODS}

Homing and straying rates for early stock coho, Rogue River Bright (RRB) fall chinook, Upriver Bright (URB) fall chinook, Willamette spring chinook, and Cowlitz spring chinook will be documented using previously published studies based on coded-wiretag (CWT) recoveries. Recent homing and straying rates for net pen releases are determined using the Pacific States Marine Fisheries Commission (PSMFC) CWT database as the source.

\section{RESULTS AND DISCUSSION}

Early stock coho exhibit a strong homing potential. Based on CWT recoveries of adults, from the 1988-90 broods released from Youngs Bay production areas, homing rates of about $98 \%$ were obtained from both CEDC's South Fork Klaskanine Hatchery and ODFW's North Fork Klaskanine Hatchery (Table 7). A homing rate of $99.2 \%$ was realized for CEDC's net pens. For purposes of this analysis, those coho caught within the Youngs Bay terminal fishery were assumed to have homed, while those coho not returning to the exact location of release were considered strays, including locations 
within Youngs Bay.

RRB stock fall chinook released at Big Creek and South Fork Klaskanine hatcheries home at a rate of about $90 \%$ (Table 8) (ODFW 1994). All releases of RRB fall chinook have been made from the hatchery sites during 1983-89. Beginning in 1990, additional releases were made from the net pens in Youngs Bay and have been restricted to 2 years, 1990 and 1992. Straying rates of net pen releases are currently not available.

URB fall chinook exhibit strong homing efficiency. Based on CWT recoveries, the 1986 and 1987 brood Hanford Reach wild upriver bright fall chinook homed at $97 \%$ and $95 \%$, with all strays accounted for at Priest Rapids Hatchery (Grimes, 1994). Upriver bright fall chinook reared and released from Priest Rapids Hatchery did not exhibit the same precise homing traits, with $73 \%$ and $61 \%$ for the same broods; however, the strays were all accounted for in the adjacent Hanford area.

Willamette spring chinook showed even stronger homing tendencies. Returns to escapement areas of CWT recoveries from:1985-86 brood hatchery production groups show that homing rates of $99.4 \%(\mathrm{~N}=705)$ and $99.6 \%(\mathrm{~N}=732)$ were achieved. The remaining strays were recovered at other Willamette River hatcheries (Ken Homolka, ODFW; personal communication).

Cowlitz spring chinook exhibit a very high homing rate. Analysis of 1986 brood CWT recoveries to escapement areas show that $100 \%$ of the expanded recoveries $(1,480)$ returned to Salkum (Cowlitz) Hatchery. For the 1987 brood $99.8 \%$ of the total escapement recoveries $(1,409)$ returned to Salkum Hatchery. The 1987 brood strays were recovered at Kalama Falls (2) and Lewis River (1) hatcheries.

Based on results of experimental releases of net pen acclimated coho (1988-90 broods) in Youngs Bay, homing rates for coho at other sites have the potential to equal homing rates observed for on-station releases from hatcheries. The ability of net pen reared salmon to accurately return to the site of release will depend on the unique characteristics of the water and the ability of the smolts to imprint on those characteristics. For chinook salmon, expectations are for homing rates to net pen sites to equal or nearly equal those observed for hatchery stocks. For RRB fall chinook, expectations are to improve upon the homing rates observed at Big Creek Hatchery utilizing study results from experimental releases in Youngs Bay.

Ranking of sites based on rearing potential was conducted during the site selection process in the initial phase of the project. One of the criteria states that "Selected sites should be located in areas with high probability for attracting returning adults". Sites influenced by a unique water source or sources would be desirable over sites with little imprinting water available. For high priority sites selected for further study, Blind Slough, Wallace.Slough, Steamboat Slough, and Cathlamet Channel received the 
highest rating of three points while Tongue Point Basin, Clifton Channel, and Deep River/Grays Bay received a rating of two points. A discussion of each site's potential to attract returning adults in terms of unique water sources is found in Chapter 1 of "Selection of Terminal Fisheries Sites" in the paragraph entitled Rearing Criteria 5 (RC 5). 
Table 7. Homing and straying of Rogue River Bright stock fall chinook, 1984-93.

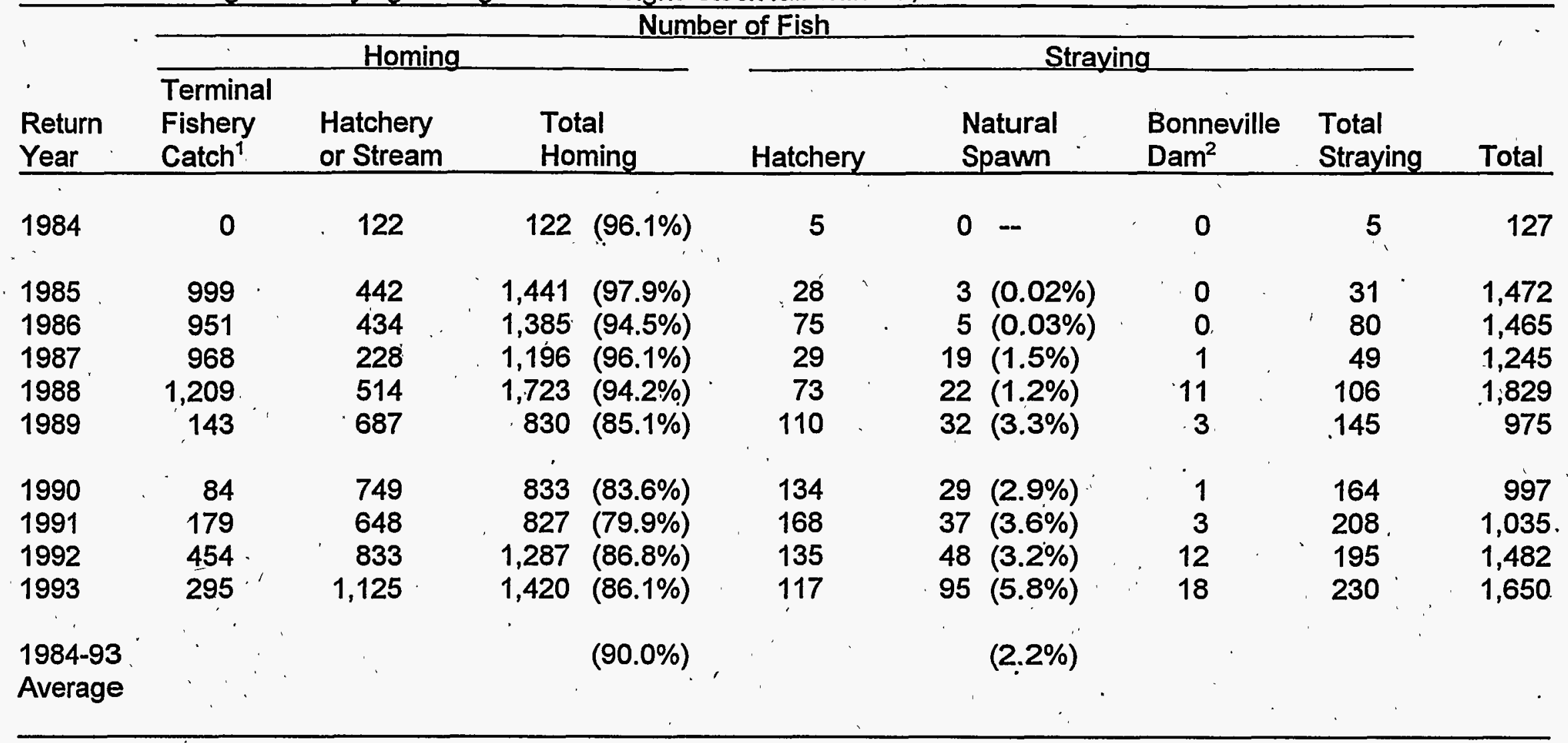

1 Catch in terminal fisheries in Youngs Bay (1984-93) and adjacent to Big Creek (1987-88) are assumed to have homed.

2. Includes catch and escapement above Bonneville Dam. 
Table 8. Escapement accountability of adult coho resulting from releases into Youngs Bay at S.F. Klaskanine Hatchery, N.F. Klaskanine Hatchery, and Tide Point net pen site, 1988-90 broods. CWT Escapement Recoveries

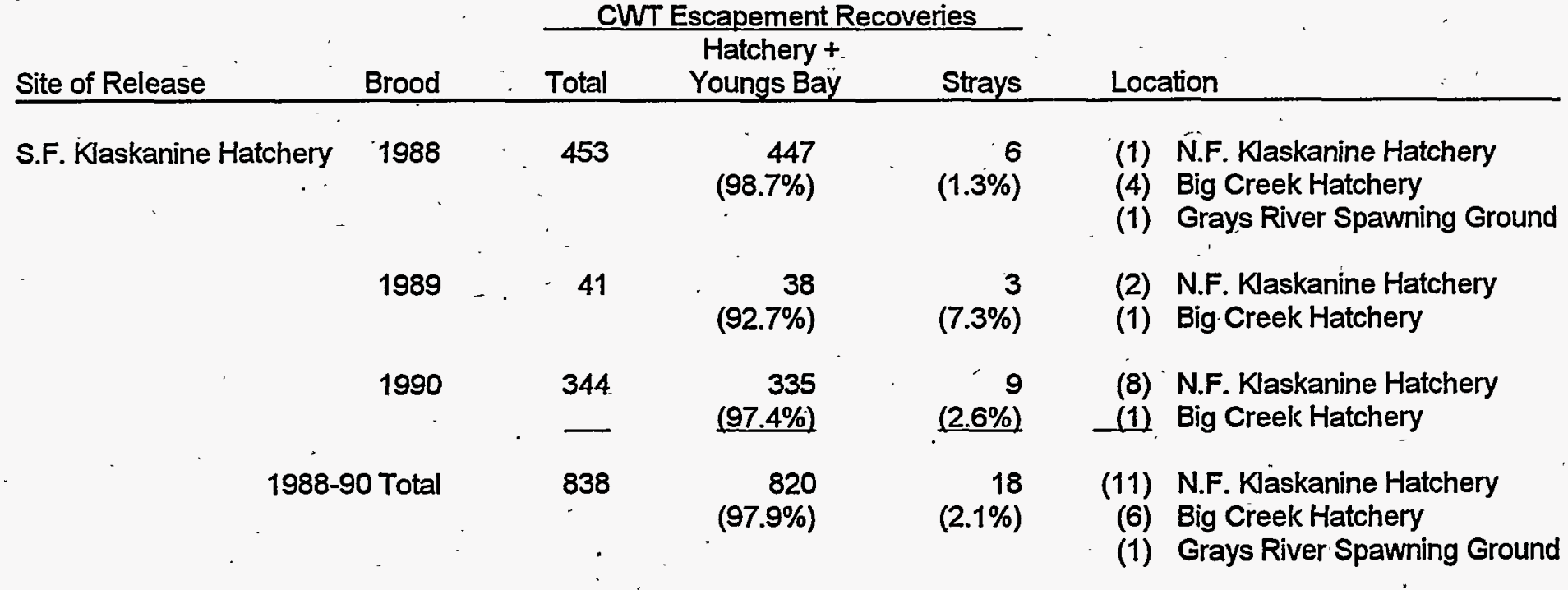

N.F. Klaskanine Hatchery 1988

1989

1990

1988-90 Total
170

494

48

$-$

712
163

(95.9\%)

490

(99.2\%)

. 47

(97.9\%)

700

(98.3\%)
4
$(0.8 \%)$

$(0.8 \%)$

7
$(4.1 \%)$

(2.1\%)

.12

(1.7\%)

(2) Lewis \& Clark Spawning Grnd.

(1) Big Creek Hatchery

(1) Rogue River Spawning Grnd.

(2) S.F. Klaskanine Hatchery

(5) Big Creek Hatchery

(1) Big Creek Hatchery

(2) S.F. Klaskanine Hatchery

(7) Big Creek Hatchery

(2) Lewis \& Clark Spawning Grnd.

(1) Rogue River Spawning Grnd.

Tide Point Net Pens

s

$1988, \quad 1,560$

1,554

(99.6\%)

400

$(98.8 \%)$

1989

405

$(98.8 \%)$

1990
$1988-90$ Total

695
2,660

684

(98.4\%)

2,638

$(99.2 \%)$
$(1.2 \%)$

$(0.4 \%)$

(1) N.F. Klaskanine Hatchery

(4) Big Creek Hatchery

(1) Fall Creek Hatchery

(1) S.F. Klaskanine Hatchery

(1) N.F. Klaskanine Hatchery

(2) Big Creek Hatchery

(1) Salmon River Hatchery

(9) N.F. Klaskanine Hatchery

(2) Big Creek Hatchery

$(1.6 \%)$

22

$(0.8 \%)$
(11) N.F. Klaskanine Hatchery

(1) S.F. Klaskanine Hatchery

(8) Big Creek Hatchery

(1) Fall Creek Hatchery

(1) Salmon River Hatchery 


\section{Disease Projections for High Terminal Rearing Sites}

\section{INTRODUCTION}

Occurrence of fish disease is dependent on the "complex interactions between the host, disease agents, and the environment" (Warren, 1991). Host susceptibility varies between species and within species at critical life stages. Since disease agents are commonly present in the aquatic environment, disease outbreaks are always potentially possible. An understanding of environmental factors such as water quality and physical stresses related to fish culture procedures is most critical to minimize the potential of disease outbreak.

Occurrence of disease in fish hatchery situations is well documented; however, with a short history of net pen acclimation and overwinter rearing, the information concerning fish health is primarily confined to large scale net pen operations in Youngs Bay, with observations on sporadic, experimental projects in Deep.River and Blind, Fisher, Bernie, and Camas sloughs. Disease projection in terminal rearing sites will be based primarily on factors relating to water quality and environmental stress.

\section{RESULTS AND DISCUSSION}

Table 9 shows a brief history of disease and mortality for net pen rearing in Youngs Bay (Jim Hill, CEDC, personal communications).

Disease problems for rearing juvenile salmonids in selected high-ranked sites is currently not believed to be an extreme limiting factor. Past experience at the net pens in Youngs Bay with coho and spring chinook has shown that rearing full term through summer months is not recommended because of high water temperature and associated occurrence of furunculosis. Current rearing experiments of overwinter rearing (November-May) and short-term acclimation (February-May) in Youngs Bay has demonstrated a low probability of disease.

Disease projections for RRB fall chinook reared in net pens is potentially higher since the rearing period is targeted to extend to August in Youngs Bay. Degradation of water quality (temperature and flow) and associated stresses incurred by juvenile RRB's will increase the likelihood of disease (Kreps, ODFW, personal communication).

A site by site disease projection at this time is not practical without quantitative water quality data for comparison. 
Table 9. Percentage mortality and incidence of disease for Youngs Bay net pen reared salmon, 1987-93 broods.

\begin{tabular}{|c|c|c|c|c|}
\hline$\frac{\text { Gro }}{\text { Brood }}$ & $\frac{\text { up }}{\text { Species }}$ & $\begin{array}{c}\text { No. Days } \\
\text { Rearing Time }\end{array}$ & $\%$ Mortality & Disease Documented \\
\hline $\begin{array}{l}87 \\
88 \\
88 \\
88 \\
88 \\
89 \\
89 \\
89 \\
89 \\
90 \\
90 \\
90 \\
90 \\
90 \\
91 \\
91 \\
91 \\
91 \\
91 \\
92 \\
92 \\
92 \\
92 \\
93\end{array}$ & $\begin{array}{l}\text { Coho } \\
\text { Sp. Chin. } \\
\text { Sp. Chin. } \\
\text { F. Chin. Rogue } \\
\text { Coho } \\
\text { Sp. Chin. } \\
\text { F. Chin. Rogue } \\
\text { Sp. Chin. } \\
\text { Coho } \\
\text { Sp. Chin. } \\
\text { Sp. Chin. } \\
\text { Coho } \\
\text { Coho. } \\
\text { Coho } \\
\text { Sp. Chin. . ' } \\
\text { F. Chin. Rogue } \\
\text { Coho } \\
\text { Coho } \\
\text { Coho } \\
\text { Sp. Chin. } \\
\text { Coho } \\
\text { Coho } \\
\text { Coho } \\
\text { F. Chin. Rogue }\end{array}$ & $\begin{array}{r}379 \\
40 \\
288 \\
28 \\
71-82 \\
14 \\
116 \\
\quad 42 \\
118 \\
14 \\
113 \\
129 \\
329 \\
14 \\
349-417 \\
14 \\
103 \\
146 \\
146 \\
363 \\
114-182 \\
14 \\
126 \\
145 \\
14 \\
-\quad 163 \\
\\
33\end{array}$ & $\begin{array}{r}10.09 \\
0.21 \\
5.89 \\
0.23 \\
0.00 \\
1.17 \\
0.06 \\
1.55 \\
0.02 \\
0.18 \\
19.32 \\
3.50 \\
12.19 \\
3.50 \\
6.45 \\
6.00 \\
20.32 \\
0.35 \\
0.00 \\
1.10 \\
0.01 \\
0.27 \\
0.07 \\
0.06\end{array}$ & $\begin{array}{l}\text { vibrio, furunculosis, Ceratomyxa shasta } \\
\text { Medicated feed required, furunculosis } \\
\text { Medicated feed required, low level furunculosis } \\
\text { Medicated feed required, low level furunculosis } \\
\text { Medicated feed required, low level furunculosis } \\
\text { Medicated feed required, furunculosis/fungus } \\
\text { Medicated feed required, furunculosis } \\
\text { Medicated feed required, furunculosis } \\
\text { Medicated feed required, furunculosis/vibriosis } \\
\text { Medicated feed required, furunculosis }\end{array}$ \\
\hline
\end{tabular}




\section{CHAPTER 3. CAPABILITY OF TERMINAL FISHING SITES TO ALLOW MANAGEABLE AND ECONOMICALLY COMPETITIVE HARVEST OF RETURNING FISH}

\section{A. Site Fishability}

\section{INTRODUCTION}

On January 21, 1994, we (ODFW, WDFW, and CEDC) held a meeting with a SFA Advisory Committee in Astoria, Oregon, to discuss issues, criteria, definitions, and other concerns relating to development of orderly and successful harvest of fish returning to terminal areas. With annual Youngs Bay terminal fisheries during the fall (since 1962) and recently, in the spring (since 1992) much experience has been gained in conducting successful terminal harvest.

In addition, terminal fisheries were established during the early 1980's in areas adjacent to Washington tributaries below Bonneville Dam; Grays, Skamokawa, Elochoman, Cowlitz, and Washougal systems. In 1983, 1987, and 1988 a terminal fishery was set adjacent to the mouth of Big Creek, Oregon. These fisheries were established to direct harvest on abundant lower river hatchery chinook while minimizing impacts on record low upriver bright fall chinook.

Although, these terminal fisheries were successful in terms of harvesting target stocks, while avoiding those stocks in need of protection, problems surfaced relating to the political and sociological aspects of these fisheries. Experience, in this case largely negative, can be used in a positive way to best accommodate orderly fisheries.

\section{RESULTS}

The following list of issues, criteria, and critical definitions was generated as a result of the meeting with the advisory committee of SFA.

1. Terminal fisheries must be managed to accommodate orderly commercial harvest. Concerns were raised about the capacity of the fishing area to provide viable fisheries for up to $\mathbf{8 0 0}$ gill-net permit holders, gear restrictions such as length of net, reciprocity between states, and a "lottery" selection system for fishermen to optimize economic benefits for each area.

2. Terminal fisheries are not intended to replace main-stem harvest opportunities. The intent is to provide sustainable harvest opportunities to maintain the industry. while 
rebuilding weak upriver salmon stocks. Commercial harvest potential must be high enough to attract and maintain a mobile fleet. Choices must be available for individual fishermen to fish various sites.

3. Allocation of harvest must be defined using a cooperative approach to resource utilization amongst commercial and recreational users. Poténtial situations of direct conflict must be avoided by time and area regulations. Areas conducive to primarily sport harvest need evaluation.

4. Commitment of agencies and users to establish and maintain the terminal fisheries concept is necessary. An assessment program that generates funds to reinvest back into the terminal fisheries program is necessary to maintain facilities and instill a sense of "ownership" in the fishery. Agency commitment in terms of providing fish of quality and quantity for release is necessary. A program to establish sound financial longevity to carry the industry. through periods of low harvest needs to be developed.

Water area of sufficient depth available for use by commercial fishers can be approximately estimated using the calculated surface area for each high priority site (Task I:C of Appendix 1). In answer to the question posed to the SFA advisors "What depth is required to effectively catch fish in proposed terminal sites"? One fisherman replied, "You put the fish in and make them come back and we'll figure out a way to catch them"! That statement seems to be over simplistic and doesn't directly address the question of sufficient depth, but the implication is that with sufficient depth for fish to swim, there is sufficient depth to catch them.

An example of a fishing technique used in Youngs Bay during the fall fishery is to begin laying out a floater gill-net in very shallow $\left(<5^{\prime}\right)$ water against the bank or sand bar and continue in a meandering pattern gradually out towards deeper water. Schooling coho following the shoreline encounter the net and are susceptible to entanglement.

In terminal areas nearest the mouth of the Columbia River, estuarial tidal differences can be as great as 12 feet. Therefore, at extreme high tide sufficient depth can exist where tide flats are exposed at low water.

The number of boats or individuals that high priority sites can accommodate using conventional cooperative fishing rules is a function of the specific site. For example, those sites with high water velocities might only be effectively fished during slack water periods. Those sites with traditional drifts are effectively fished during strong tidal and river movement.' Other sites may require special techniques and stationary gear.

The estimates of maximum number of boats or fishermen will be made based on landing statistics of past terminal fisheries, fishing area of individual șites, and characteristics of 
each site. The number of fishermen landing salmon in Youngs Bay for peak catch days is an indication of capacity when related to the available fishing area. In addition, the number of fishermen landing salmon in past Oregon (Big Creek) and Washington (Grays, Skamokawa/Elochoman, Cowlitz, and Camas) terminal fisheries on peak catch days can be applied. Tables 10 and 11 show peak day catches and deliveries for past selected terminal.fisheries and estimated peak day effort for high priority sites.

1. The Tongue Point basin estimate of 42 boats is based on the calculated density values for Youngs Bay and estimated surface area. Fishing effort will likely be concentrated during slack tide periods as on Youngs Bay; although, development of "drifts" where boats can orderly take turns fishing is a possibility. Also, since the majority of the basin is deeper than 20 feet, shallow floater gill-nets can be fished with little danger of snagging, and restriction of net length may not be necessary.

The Tongue Point basin estimate of 42 boats is considered conservative because of deeper water in the basin compared to Youngs Bay.

2. The Deep River/Grays Bay estimate of 54 boats is based on density values observed for the 1981 Grays Bay fishery and the 1980 Skamokawa/Elochoman fishery applied to the estimated surface area. Fishing area in Deep River and Grays Bay will likely be with heavy leaded gill-nets and fished during slack tidal periods. Limited areas in lower Grays Bay may be conducive to orderly drift fishing.

3. The Blind Slough site (including upper Knappa Slough) can accommodate approximately 71 boats assuming the density of boats observed in the $1988 \mathrm{Big}$ Creek terminal fishery and the estimated surface area. Fishing methods preclude drift fishing and require fishing periods of minimal current with heavy leadlines to avoid numerous snags. Also, gill-nets restricted to $\leq 100$ fathoms will likely be necessary considering the narrow character of the slough.

4. Steamboat Slough can accommodate 13 boats based on peak boat density of during the 1980 Skamokawa/Elochoman fishery and estimated area available for fishing. As with Blind Slough, fishing activity will likely be restricted to slack water periods and require use of short nets ( $\leq 100$ fathoms) with heavy leadlines. Snags are numerous within Steamboat Slough and the channel is narrow.

5. Presently, at Clifton Channel a formal drift is established using diver type gill-nets fishing nearly the length of the channel. The number of fishermen with "drift rights" is presently five. To maximize the number of boats fishing in Clifton Channel, periods of slack water can be fished with an estimated 29 boats, calculated using a boat density of 24 (1991 Youngs Bay fishery) and surface area of $1.22 \mathrm{mi}^{2}$. 
Table 10. Selected peak daily catches and deliveries for past Columbia River terminal fisheries.

\begin{tabular}{|c|c|c|c|c|c|c|c|c|}
\hline Area & Date & $\frac{\text { Catch ir }}{\text { Chinook }}$ & $\frac{\text { Number }}{\text { Coho }}$ & $\frac{f \text { Fish }}{\text { Total }}$ & $\begin{array}{l}\text { Numbers } \\
\text { of Fish } \\
\text { Tickets }\end{array}$ & $\begin{array}{l}\text { Numbers } \\
\text { of Boats }\end{array}$ & $\begin{array}{r}\text { Area } \\
\text { (sq.mi.) }\end{array}$ & $\begin{array}{l}\text { Boats } \\
\text { Per } \\
\text { sq.mi. }\end{array}$ \\
\hline Bay & $\begin{array}{r}9 / 7 / 87 \\
9 / 7 / 91 \\
9 / 15 / 94\end{array}$ & $\begin{array}{r}3,135 \\
194 \\
9\end{array}$ & $\begin{array}{r}1,009 \\
8,047 \\
16,071\end{array}$ & $\begin{array}{r}4,1 \\
8,2 \\
16,0\end{array}$ & $\begin{array}{l}143 . \\
137\end{array}$ & & & $\begin{array}{l}18 \\
24\end{array}$ \\
\hline Big C & $\begin{array}{l}9 / 9 / 87 \\
9 / 7 / 88\end{array}$ & & $\begin{array}{r}0 \\
57\end{array}$ & & $\begin{array}{r}5 \\
11\end{array}$ & & & $\begin{array}{r}54 \\
126\end{array}$ \\
\hline Graj & $\begin{array}{r}8 / 28 \\
9 / 1\end{array}$ & 9 & $\begin{array}{r}834 \\
93\end{array}$ & & $\begin{array}{r}177 \\
52\end{array}$ & (35) (67\%) & $1 . \overline{-}$ & \\
\hline $\begin{array}{l}\text { Skamokawa } \\
\text { Elochoman }\end{array}$ & $\begin{array}{r}9 / 5 / 80 \\
9 / 2 / 81\end{array}$ & $\begin{array}{r}1,397 \\
745\end{array}$ & $\begin{array}{r}1,318 \\
123\end{array}$ & $\begin{array}{r}2,715 \\
868\end{array}$ & $\begin{array}{l}43 \\
36\end{array}$ & $\begin{array}{l}(29) \\
(24)\end{array}$ & & 6 \\
\hline Cow & $\begin{array}{l}9 / 9 / 80 \\
9 / 4 / 81\end{array}$ & $\begin{array}{l}1,779 \\
2,101\end{array}$ & $\begin{array}{l}48 \\
58\end{array}$ & $\begin{array}{l}2,2 \\
2,6\end{array}$ & $\begin{array}{l}64 \\
87\end{array}$ & $\begin{array}{l}(43)(67 \%) \\
(58)(67 \%)\end{array}$ & $\begin{array}{l}0.75 \\
0.75\end{array}$ & 5 \\
\hline Cam & $\begin{array}{r}9 / 9 / 80 \\
9 / 10 / 81\end{array}$ & $\begin{array}{r}1,091 \\
690\end{array}$ & $\begin{array}{l}593 \\
122\end{array}$ & $\begin{array}{r}1,684 \\
812\end{array}$ & $\begin{array}{l}13 \\
15\end{array}$ & $\begin{array}{r}(9)(67 \%) \\
(10)(67 \%)\end{array}$ & $\begin{array}{l}0.26 \\
0.26\end{array}$ & $\begin{array}{l}3 \\
3\end{array}$ \\
\hline
\end{tabular}

1 Number of boats for Grays Bay, Skamokawa/Elochoman, Cowlitz and Camas are estimated by the average proportion (67\%) of boats per fish ticket for Youngs Bay and Big Creek.

Table 11. Capability for harvest in high priority sites in terms of numbers of boats.

\begin{tabular}{lccc}
\hline Site & $\begin{array}{c}\text { Surface } \\
\text { Area (sq.mi.) }\end{array}$ & $\begin{array}{c}\text { Density } \\
\text { (Boats/sq.mi.) }\end{array}$ & $\begin{array}{c}\text { Estimated Peak } \\
\text { Day effort }\end{array}$ \\
\hline Tongue Pt. & 1.74 & 24 (Youngs Bay, 1991) & 42 \\
Deep River/ & 0.30 & 63 (Skamokawa, 1980) & 19 \\
Grays Baỳ & 1.02 & 34 (Grays Bay, 1981) & 35 \\
$\begin{array}{l}\text { Blind Slough/ } \\
\text { Knappa Slough }\end{array}$ & 0.29 & 126 (Big Creek, 1988) & 37 \\
$\begin{array}{l}\text { Steamboat Slough/ } \\
\text { Skamokawa }\end{array}$ & 0.27 & 126 (Big Creek, 1988) & 34 \\
Clifton Channel & 0.20 & 63 (Skamokawa, 1980) & 13 \\
Cathlamet Channel & 1.22 & 24 (Youngs Bay, 1991) & 29 \\
Wallace Slough & 4.04 & 24 (Youngs Bay, 1991) & 97 \\
\hline
\end{tabular}

1 Density values used are derived from Table 10 
6. Cathlamet Channel like Clifton Channel has established drift areas accommodating boats. Deeper and wider than Clifton and using densities observed during the 1991 Youngs Bay fishery, as many as 97 boats could participate.

7. Wallace Slough is similar to Cathlamet and Clifton channels in that 17 boats have drift rights in the slough. Fishing is conducted using floater gill-nets during an ebb current. During slack tidal periods, an estimated 43 boats can utilize the fishing area based on the boat density of 63 (1980 Skamokawa fishery) and surface area of $0.68 \mathrm{mi}^{2}$.

The estimates for the maximum number of boats that high priority sites can accommodate are subjective since statistics from previous terminal fisheries are applied to proposed areas.

Estimates of snag clearing needs by site were obtained during test fishing operations during the spring and fall utilizing expert opinions solicited from test fishermen at each specific site. Cost estimates associated with snag removal were discussed and evaluated in terms of improved harvest capabilities.

1. Tongue Point Basin is a large water body with depth greater than 20 feet in the majority of the fishing area and complex flow patterns during both stages of tide. Because of these characteristics snags are not a concern. Snags were not a problem during both spring and fall test fishing programs. No cost estimates associated with snag removal are necessary.

2. The lower stretches of Deep River combine with the flats and channel ways of Grays Bay to form this fishing area. As with most backwaters of the lower Columbia River, there is a history of log storage, especially in Deep River, resulting in a need for some clearing. Making the area fishable would require limited snag removal, at levels approximating $\$ 2,000$, to open up selected areas within the lower river. Of more importance, though, would be modifications to standard gillnet practice (Les Clark, gillnetter, personal communication). Shortening of nets and fishing during slack tides will best accommodate the irregular nature of the channels being fished.

3. Blind Slough and adjacent Knappa Slough downstream to Knappa dock is an area of $\log$ rafting and storage operations. Associated rubble and debris such as cable, log strapping material, and "sinkers" (submerged logs) litter the bottom, especially in Knappa Slough. Initial clearing of the bottom would require a large investment. of time and money since the area has never been open to fishing (Alan Takalo, gillnetter, personal communication). During spring and fall test fishing, snags were not a problem since fishing was conducted during periods of slack tide in Knappa Slough. In Blind Slough fishing nets with heavy leadline minimizes the snagging problem during periods of low water velocity. Removal of snags in Blind Slough is not cost effective nor necessary to optimize harvest opportunity. 
4. Steamboat Slough, as described under Task I:A (Appendix 1), has restricted fishing area. The channel way is narrow and shallow in some areas. There is a history of log boom storage throughout the length of the slough. During spring and fall test fishing there was a need to fish only during slack tides to avoid the threat of rotted pilings and sunken logs. The entire fishery would be conducted in a narrow waterway, at slack tide periods to account for potential problems. Clearing would not be cost effective as fishing could be conducted during restricted flow periods.

5. Clifton Channel is an established fishing drift that is maintained by the drift members prior to season openings. The shoreline areas along Tenasillahe Island; however, are used for log raft storage with potential for significant debris. Cost associated with snag removal are minimal $(\$ 2,000)$ in the driftable stretch of the channel, while removal is not advised along the shorelines (Jack Marincovich, gillnetter, personal communication). During spring and fall test fishing, snags were rarely a problem.

6. Cathlamet Channel would require no snag removal. This extensive waterway, with a history of spring and fall fishing, is regularly fished by local gillnetters who, in the process of maintaining the various drift sites, keep the area fairly well cleared (Art Pedersen, gillnetter, personal communication).

7. Wallace Slough drift, historically, has been fished during winter, spring, and summer seasons; however, in recent years fished only infrequently. During spring and fall test fishing, no problems were encountered with snags. The driftable area in the lower half of the slough was clear of major snags. The area adjacent to the mouth of the Clatskanie River is not driftable and presently is fishable only at slack tide. Snag removal at Wallace Slough would be needed to keep the driftable area clear and to increase the driftable area. Approximately $\$ 2,000$ would be needed initially to clear snags to increase the drift area (James Hogan, gillnetter, personal communication). 


\section{B. Evaluate Application of Various Fishing Gear Types to Terminal Sites}

\section{INTRODUCTION}

An evaluation of selective fisheries sponsored by the Pacific Salmon Commission (PSC) is currently being conducted to address the feasibility of implementing a comprehensive management program requiring (1) mass marking of harvestable hatchery stocks and (2) selective harvest using gear types that optimize the survival of nontarget fish species. The Implementation and Evaluation Work Group, comprised of scientists from various agencies and tribal affiliations, is evaluating application of live capture gear types that would best meet the requirements of unharmed release of nontargeted fish species for both marine and freshwater sport and commercial fisheries.

Another recent study entitled, Live Capture Technologies for Pacific Salmon prepared by Triton Environmental Consultants, LTD and funded by British Columbia's Ministry of Environment, Lands and Parks provides a thorough review and evaluation of gear types and application to marine and freshwater environments.

Recommendation for utilization of live-capture gear types in potential Columbia River terminal harvest areas should be based on the ability of current management practices (including use of gill nets) to hold mortality of nontarget fish stocks within "acceptable" levels. If conventional gill-nets used in terminal fishing areas are found to have unacceptable levels of impact on nontarget fish, use of live-capture gear types may be necessary.

\section{FINDINGS}

1. "Gill-net gear release mortality rates are relatively high, hence the feasibility of using this gear for selective fisheries is low" (PSC,1995),

2. "Hook-and-line gears, traps, reef nets, beach seines, and fish wheels have typically lower release mortalities than gill-nets and purse seines, and are the most promising for successful selective fisheries" (PSC,1995),

3. "Recreational hook-and-line gears have a lower release mortality rate than commercial troll gear. Several authors have reported the release mortality rates associated with recreational fisheries for adult coho salmon in marine and riverine areas to be in the range of $6-10 \% "$ (PSC,1995), and

4. Of live capture options evaluated for British Columbia commercial fisheries, modifications to seining is the only method that can provide for release of nontarget species without reduction in the existing fishing fleet (Triton Environmental Consultants, LTD). 


\section{DISCUSSION}

Findings of the PSC Implementation and Evaluation Work Group and Triton Environmental Consultants, LTD are identical reläting to commercial gear types suitable for selective live capture in mixed stock harvest situations, while allowing for releasing of nontargeted species unharmed. Both reports conclude that seines as they are presently used are not a suitable gear type for use under proposed selective fishery regulations. Traps such as reef nets, trap nets, and fish wheels are presently the only known gear types that can effectively produce acceptable low release mortality rates. If mortality rates of nontargeted species are not within acceptable limits using conventional gill-net gear, traps are the only gear type presently available.

The advantage - of fish traps (including fish wheels) are quite apparent, low release mortality rates, high quality of fish captured, and ease of operation and maintenance. Disadvantages and issues to anticipate are; a reduction in the existing fishing fleet, difficulty in site selection, variable harvest efficiency due to changing hydrological and climatological conditions, and reestablishing traps as legal gear. Fish wheels were prohibited in Oregon in 1927 and in Washington, traps and fish wheels were prohibited in 1935. In 1949 traps were prohibited in Oregon (WDFW and ODFW, 1994).

Presently, gill-net gear is in use in the Youngs Bay terminal fishery with acceptable low interception and mortality rates associated with nontargeted species. In 1994, 10 upriver spring chinook (less than one Snake River wild spring chinook) and an estimated 10 or 15 upriver fall chinook (approximately 0.1 Snake River wild fall chinook) were estimated to be caught during the Youngs Bay spring and fall seasons. The projected levels of incidental catch were determined to not jeopardize the continued existence of listed Snake River salmon species as indicated in biological opinions prepared by the National Marine Fisheries Service under section 7 of the Endangered Species Act on 1994 winter, spring, and summer season fisheries and 1994 fall season main-stem recreational fisheries, tributary and terminal area fisheries, and Bonneville Dam trapping operations conducted under the Columbia River Fish Management Plan. At this time, preliminary analysis of 1994 Youngs Bay chinook catches indicate levels were well within guidelines stated in the biological opinions.

Implementation of live-capture gear to replace conventional gill-net gear at this time is not needed in the Youngs Bay terminal fishery. Other high priority sites will need to be evaluated on a site specific basis; however, if levels of nontargeted listed species are similar to that observed in Youngs Bay, conventional gill-net gear may be acceptable. 


\section{CHAPTER 4. POTENTIAL FOR HARVEST OF TARGET AND NON- TARGET FISH SPECIES.}

\section{A. 1994 Spring Test Fishery in Potential Terminal Fishing Sites}

\section{INTRODUCTION}

In preparation for potential harvest in terminal fishing areas, gillnet test fisheries were conducted in each of the seven areas designated as having highest terminal fishery potential. Test fisheries will be conducted in all areas over the next few years to establish a baseline of information. The general purpose in having test fisheries is to assess the harvest potential in selected sites in terms of catch and timing of nontarget . fish stocks, variation in gear type, and fishing area boundaries.

With salmon runs being particularly weak in 1994 (Table 12), added emphasis has been placed on protecting upriver spring chinook. The 1994 spring test fishery was allowed following firm ESA mandated guidelines of a maximum of 20 upriver spring chinook, with no more than seven mortalities, for all fishing sites combined.

Plans are to continue this program each spring for the duration of the terminal fishery experimental study. Results during years of adult returns from test rearing programs will provide information to formulate season dates for full fleet evaluation fisheries. A fall test fishing program will be conducted with the same objectives and structure as the spring program.

This report is a summarization of data pertinent to this incidental catch monitoring project, including success by area, CWT, age and skin color data. One report alone cannot be considered as a true representation of general conditions in any area, and must be reviewed in the context that it is only part of a multiple-year and multipleseason study.

\section{METHODS}

Four Oregon and three Washington sites were selected based on rearing and harvest criteria established and described under Project Objective \#1. All selected sites were within Columbia River commercial statistical Zone 2. The areas sampled were: 


\begin{tabular}{lcc} 
Site & State & River Mile \\
\cline { 2 - 3 } Tongue Point Turning Basin & OR & 18 \\
Deep River/Grays Bay. & WA & 22 \\
Blind Slough & OR & 27 \\
Steamboat Slough/Skamokawa & WA & 34 \\
Clifton Channel & OR & 36 \\
Cathlamet Channel & WA & 40 \\
Wallace Slough & OR & 49
\end{tabular}

Fishing was conducted over the period of 20 April through 2 June of 1994 with each site fished weekly for a total of six trips per site. At Deep River fishing was delayed by a week.

Each site was fished by a single local gillnetter for all six weeks, with an ODFW or WDFW observer aboard every trip. Fishermen were Joe Parker, Les Clark, Alan Takalo, Art Pedersen, Jack Marincovich and Jim Hogan. Generally, three drift locations were fished at each site weekly in order to spread effort geographically, with fishing conducted during high or low, and daylight or dark, ticles. Each boat distributed effort between both small ( $5-6$ inch) and large ( $7-8$ inch) mesh nets in order to provide a reference of the occurrence of the larger spring chinook and smaller steelhead. Gear specifications are displayed in Table 13. Generally, each drift of the net wass fished for about $1 / 2$ hour, with a day's three drifts being distributed over the change of the high or low tide.

Observations made were: 1) net specifications and fathoms fished, 2) set location, 3) weather, water temperature and turbidity (Secchi disk), 4) layout and pickup times, and 5) catch of all fish species with biological data:

Chinook: Data collected with each fish removed from the gillnet were fork length, condition (live or dead), marine mammal damage, occurrence of mark and/or CWT, stock using visual stock identification (VSI) and scales removed for aging. VSI is a method to determine spring chinook stocks (upriver or lower river origin) based on phenotypic differences. This is the accepted methodology to determine the stock composition of the mainstem March sport fishery in recent years. Live fish were opercle punched to identify recaptures. If the fish was killed by the net, or coded-wire tagged, fish weight and sex were recorded, and the snout removed for later CWT removal.

Steelhead: Data collected include fork length, race/maturity, fin marks and CWTs, and marine mammal damage. Scales were taken for aging and determination of hatchery/wild. Live fish were opercle punched to identify recaptures. 
Sturgeon: All sturgeon caught were sampled for total and fork length, and examined for the occurrence of spaghetti tags or tag scars. Depending on the availability of time, sturgeon over 80 centimeters in fork length were spaghetti tagged and scute marked.

Other species: All other species of fish were enumerated by fishing site, time and gear type.

Water temperature and turbidity readings were taken at each location except when darkness prevented turbidity readings or instruments were not available. The data is presented to compare relative temperature and turbidity at each location for a given week and the change observed through time for each location.

Chinook, steelhead and sturgeon catches at each site were converted to a standardized unit of Catch per Hour per 100 Fathoms of Net to compare catch rates within sites as well as between sites. Actual fishing time of the gear is difficult to determine since pick time (beginning to end) was highly variable and depended on the amount of gear in the water and number of fish caught. Pick time varied from as little as six minutes (Tongue Point) to as much as 68 minutes (Clifton Channel). Calculation of fishing time for purposes of this study is defined as:

$$
\frac{\left(S_{E}-S_{B}\right)}{2}+\left(P_{B}-S_{E}\right)+\frac{\left(P_{E}-P_{B}\right)}{2}
$$

Where, $\quad S_{E}=$ Time at end of set,

$S_{B} \quad=$ Time at begin of set;

$P_{E} \quad=$ Time at end of pick,

$P_{B} \quad=$ Time at begin of pick, and

$\left(P_{B}-S_{E}\right)$, = "Soak" time period that the total net is in the water.

\section{RESULTS AND DISCUSSION .}

The total catch of chinook at all sites was comprised of 52 lower river type and five upriver type, with most lower river type (40) and all upriver type captured during the first half of the program (Tables 14 and 15). Of the 57 fish total, 16 were immediate mortalities, including two upriver origin mortalities. Age composition of catch based on scale readings showed $2 \% 3$-year-olds, $35 \%$ 4-year-olds, $61 \% 5$-year-olds and $2 \% 6$ year-olds. CWTs were recovered from six chinook; five Willamette River fish and one Klickitat River fish. At Cathlamet three Willamette tags (7-40-43, 7-54-36, and 7-55-16) and the Klickitat River tag (63-56-04) were recovered. One tag of Willamette origin was recovered at both Wallace (7-50-21) and Clifton (7-55-04). 
A total of 21 steelhead were caught, 12 during the last week. Summer run steelhead were dominant with 16 (all adipose clipped hatchery fish), while two kelt steelhead (both wild) were caught. Three steelhead were not examined. A total of five steelhead were immediate mortalities.

Sturgeon catch totalled 1,824 fish at all sites, coming mostly from the three upriver sites of Wallace Slough, Clifton Channel and Cathlamet Channel.

Sightings of harbor seals were'noted only at Tongue Point and Clifton Channel while no sea lions were observed at any site. Marine mammal inflicted injuries were noted on seven chinook and one steelhead. The remains of an unidentified salmon (gill arch) found in the net was also noted. Marine mammal interactions are a concern and can interfere with evaluation of catches.

Total catches and catch per unit of effort (CPUE) at each site are displayed in Tables 14 and 15. Sample data, by drift, are totalled in Appendix 2. Tongue Point, Blind Slough and Deep River showed the lowest salmonid harvest and CPUE $(<4$ fish or 0.3 fish/hour/100 fathoms of net). Higher numbers were caught at Steamboat Slough, Cathlamet Channel, Clifton Channel, and Wallace Slough.

Tongue Point (Figure 3): Fishing was conducted as a conventional floater drift net fishery. No chinook were caught, though a live chinook dropped from the net just prior to coming over the roller. Of the three steelhead caught, all were adipose clipped summer run, and two were mortalities. The white sturgeon catch of 71 fish was lower than anticipated. In addition, five shad were caught.

Deep River/Grays Bay (Figure 4): Operations were conducted with a large (7 $1 / 4$ inch) or small ( 6 inch) mesh net at three sites. The Deep River site was always fished at high tide (due to shallow entry) with the small mesh web, whereas the two Grays Bay sites were fished at either high or low tide with the larger mesh net. The waters of the lower Deep River have depth at high tide, but are cluttered with sunken logs from old rafts. Grays Bay, though-mostly shallow, has depths that can be fished. Future test fishing will expand into new sites; with smaller meshed gear, to better represent fish abundance by species and size. A total of one chinook (lower river origin), one steelhead (adipose clipped), 48 sturgeon, two shad and one starry flounder were caught. All fish were caught at the Grays Bay sites.

Blind Slough (Figure 5): Fishing operations were restricted to heavy leaded gear because of bottom debris primarily resulting from log raft storage. Snag removal would be a major expense for this site. Two sites were located within Blind Slough while one site was at the Knappa dock approximately $1 / 2$ mile below the mouth of Blind Slough. Only one chinook was caught during the 
program, no steelhead, and 43 white sturgeon (all at the lower sites). Other species in the catch were 3 carp and a common loon (mortality) which was caught at the upper most location.

Steamboat Slough/Skamokawa (Figure 6): Fishing sites of the Steamboat Slough area include a drift within the slough, another at Skamokawa, and two in the mainstem gap between Steamboat and Elochoman sloughs. Due to the great variety in fishing conditions a number of nets were used. All were floater nets, with the large mesh nets being $71 / 2$ to 8 inch and the small mesh net being $5-51 / 4$ inch. The Skamokawa and Steamboat drifts were fished with short (60 fathom) nets, while the gap drifts were fished with 200 fathom nets extending into the main channel. All five chinook caught were of lower river origin, four from the first half of the program. Six steelhead, five sturgeon, 18 shad, and one squawfish were caught. In comparing net sizes, all but one fish were caught in the small mesh nets. As for day/night fishing, chinook success was fairly even by time, steelhead were all caught in daylight hours, and all sturgeon were caught at night.

Clifton Channel (Figure 7): Fishing was conducted without any problems. Clifton Channel is an established fishing drift. The gear employed was a $71 / 2$ inch mesh diver gillnet which was restricted to fishing periods of ebb and a $55 / 8$ inch floater gillnet which was restricted to high and low water slack current periods. Sixteen chinook were caught including three of upriver origin. All were caught in the first half of the program. All but one were caught in the large mesh gear. A total of three steelhead were caught, all from the small mesh gear, at the lower most location, and alive. Of the 412 white sturgeon, the majority (383) were caught in the first half of the program, and all except 15 were caught in the large mesh gear. Shad was the only other species caught.

Cathlamet Channel (Figure 8): Floater gillnets were used; the small mesh net had 5 inch mesh, while the large mesh net had 100 fathoms of $77 / 8$ inch and 100 fathoms of 8 inch mesh. Four drifts were fished, from one just above the Cathlamet-Puget Island bridge, to three evenly spaced to the downriver end of Cathlamet Channel. A total of 18 chinook (one upriver), seven steelhead, 145 sturgeon and 17 shad were caught. The majority of chinook (16) was caught in the large net, as was the case with sturgeon (101). Over the six week period there was considerably more night time fished, though day and night success was fairly equal for chinook and sturgeon. Six of the seven steelhead were caught during daytime.

Wallace Slough (Figure 9): Fishing was conducted with floater gillnets of large (7 1/4 inch) and small (5 3/8 inch) mesh. After discovery of large numbers of sturgeon on the Patton drift on April 21, operations were restricted to Wallace 
Slough except for some exploratory drifts using caution. No problems were encountered on the Wallace Slough drift. Chinook salmon catch totalled 16, of which 15 were of lower river origin. All but one were caught in the first half of the program. Only one steelhead was caught. A total of 1,100 white sturgeon were caught, with 582 netted on April 21 in one short period set with small mesh. Except for 13 sturgeon, the remaining fish were caught in Wallace Slough. Other fish species caught were seven squawfish and two carp.

\section{Catch by Net}

Comparisons of catch by mesh size were made by grouping nets in to either a small (5 - 6 inch) or large (7 - 8 inch) category (Table 16). In general, salmon were caught equally between the two nets, whereas steelhead and sturgeon were caught more in the small mesh net.

\section{Day and Night}

Table 17 presents catch and CPUE for day and night sets. Overall, more time was spent fishing at night ( 74 sets) than at day (54 sets) due to efforts to avoid clear fishing waters. Chinook and steelhead catch rates were surprisingly similar during day and night sets. There was a general paltern of sturgeon being caught more at night than day.

\section{CONCLUSIONS}

1. Tongue Point Basin, Deep River/Grays Bay, and Blind Slough sites show the greatest harvest potential in terms of low catch rates of nontarget salmonid species and white sturgeon.

2. Wallace Slough and Clifton Channel show guarded harvest potential in terms of nontarget salmonid species and white sturgeon with the following specifics: A narrow time window for commercial harvest potential appears to be during the last half of May. catch of sublegal sized white sturgeon may restrict harvest efficiency.

3. Steamboat Slough/Skamokawa also shows guarded harvest potential in terms of interception of nontarget species. A harvest window during the last half of May is reasonable in terms of chinook interception, but summer steelhead may be a concern, with the highest CPUE observed for all sites.

4. Cathlamet Channel site shows the least harvest potential in terms of interception of nontarget species. No window of harvest opportunity is shown in terms of spring chinook in 1994. The steelhead CPUE is highest relative to Tongue Point, Deep River and Blind Slough sites. 
5. Use of small ( $5-6$ inch) and large ( $7-8$ inch) mesh gear was effective to show the relative magnitude and diversity of species within the test fishing sites.

6. Comparison of CPUE for day and night show similar catch rates for chinook and steelhead. Catch rates for white sturgeon are higher during night sets.

7. Boundaries for terminal fishing were appropriate for all Oregon sites except for the Wallace area, where fishing locations outside of Wallace Slough needs further evaluation. For all Washington sites evaluation should continue where fishing occurred in the mainstem.

\section{RECOMMENDATIONS}

Continue the spring test fishing program using the same general methodology as in 1994.

Expand operations at: 1) locations upstream and adjacent to the Tongue Point basin in the South Channel (mouth of John Day River to the mouth of Bear Creek), and 2) downstream and adjacent to the Blind Slough site including Knappa, Big Creek, and Calendar sloughs. 
Table 12. Minimum numbers (in thousands of adults) of lower river spring chinook, upriver spring chinook, and lower river summer steelhead entering the Columbia River, 1980-94.

\begin{tabular}{lrrc}
\hline & \multicolumn{2}{c}{ Spring Chinook } & Lower River \\
\cline { 2 - 3 } Year & Lower River & Upriver & Summer Steelhead \\
\hline 1980 & 73.1 & $<53.1$ & 47.8 \\
1981 & 93.9 & $<63.6$ & 56.6 \\
1982 & 110.1 & 71.1 & 49.1 \\
1983 & 93.3 & 55.9 & 19.7 \\
1984 & 115.6 & 47.4 & 68.5 \\
1985 & & & \\
1986 & 83.3 & 84.7 & 56.9 \\
1987 & 90.6 & 120.5 & 89.9 \\
1988 & 133.3 & 100.0 & 58.4 \\
1989 & 145.9 & 97.0 & 77.9 \\
& 136.9 & 83.3 & 35.0 \\
1990 & & & \\
1991 & 151.2 & 99.4 & 61.9 \\
1992 & 130.3 & 59.7 & 31.8 \\
1993 & 105.7 & 89.8 & 46.5 \\
1994 & 91.6 & 111.5 & 44.3 \\
\hline
\end{tabular}

Source: WDFW and ODFW, 1994. 
Table 13. Net specifications for 1994 spring terminal test fishery, by site.

\begin{tabular}{|c|c|c|c|c|}
\hline Site & Net Type & Mesh Size & Length & Details \\
\hline Tongue Point & $\begin{array}{l}\text { 1.Floater } \\
\text { 2.Floater }\end{array}$ & $\begin{array}{l}51 / 2^{\prime \prime} \\
7^{\prime \prime}\end{array}$ & $\begin{array}{l}200 \mathrm{fm} \\
250 \mathrm{fm}\end{array}$ & $\begin{array}{l}14-17 \mathrm{ft} \text {. deep } \\
18 \mathrm{ft} \text {. deep }\end{array}$ \\
\hline Deep River & $\begin{array}{l}\text { 1.Floater } \\
\text { 2.Floater }\end{array}$ & $\begin{array}{l}71 / 4^{\prime \prime} \\
6^{\prime \prime}\end{array}$ & $\begin{array}{l}120 \mathrm{fm} \\
50 \mathrm{fm}\end{array}$ & $\begin{array}{l}30 \mathrm{ft} \text {. deep } \\
16 \mathrm{ft} \text {. deep }\end{array}$ \\
\hline Blind Slough & $\begin{array}{l}\text { 1.Floater } \\
\text { 2.Floater }\end{array}$ & $\begin{array}{l}53 / 4^{\prime \prime} \\
71 / 4^{\prime \prime}\end{array}$ & $100 \mathrm{fm}$ & $\begin{array}{l}15 \mathrm{ft} \text {. deep w/ } \\
\text { heavy lead line } \\
15 \mathrm{ft} \text {. deep w/ } \\
\text { heavy lead line }\end{array}$ \\
\hline Steamboat Slough & $\begin{array}{l}\text { 1.Floater } \\
\text { 2.Floater } \\
\text { 3.Floater } \\
\text { 4.Floater }\end{array}$ & $\begin{array}{l}51 / 4^{\prime \prime} \\
71 / 2^{\prime \prime} \\
5^{\prime \prime} \\
8^{\prime \prime} \\
77 / 8^{\prime \prime} \\
51 / 4^{\prime \prime}\end{array}$ & $\begin{array}{l}20 \mathrm{fm} \\
40 \mathrm{fm} \\
200 \mathrm{fm} \\
100 \mathrm{fm} \\
100 \mathrm{fm} \\
60 \mathrm{fm}\end{array}$ & $\begin{array}{l}15 \mathrm{ft} . \text { deep } \\
30 \mathrm{ft} . \text { deep } \\
24 \mathrm{ft} \text {. deep } \\
22 \mathrm{ft} \text { deep } \\
34 \mathrm{ft} \text {. deep } \\
15 \mathrm{ft} \text { deep }\end{array}$ \\
\hline Clifton Channel & $\begin{array}{l}\text { 1.Floater } \\
\text { 2.Diver }\end{array}$ & $\begin{array}{l}55 / 8^{\prime \prime} \\
71 / 2^{\prime \prime}\end{array}$ & $\begin{array}{l}100 \mathrm{fm} \\
190 \mathrm{fm}\end{array}$ & $\begin{array}{l}60 \text { meshes } \\
60 \text { meshes w/ } \\
12 \text { ft. slacker }\end{array}$ \\
\hline Cathlamet Channel & $\begin{array}{l}\text { 1.Floater } \\
\text { 2,Floater }\end{array}$ & $\begin{array}{l}8 " \\
77 / 8^{\prime \prime} \\
5^{\prime \prime}\end{array}$ & $\begin{array}{l}100 \mathrm{fm} \\
100 \mathrm{fm} \\
200 \mathrm{fm}\end{array}$ & $\begin{array}{l}22 \mathrm{ft} \text { deep } \\
34 \mathrm{ft} \text { deep } \\
24 \mathrm{ft} \text { deep }\end{array}$ \\
\hline Wallace Slough & $\begin{array}{l}\text { 1.Floater } \\
\text { 2.Floater }\end{array}$ & $\begin{array}{l}53 / 8^{\prime \prime} \\
71 / 4^{\prime \prime}\end{array}$ & $\begin{array}{l}153 \mathrm{fm} \\
150 \mathrm{fm}\end{array}$ & $\begin{array}{l}16 \mathrm{ft} \text { deep } \\
16 \mathrm{ft} \text { deep }\end{array}$ \\
\hline
\end{tabular}


Table 14. Spring terminal test fishery catch and CPUE, by area, 1994.

\begin{tabular}{|c|c|c|c|c|c|c|}
\hline \multirow[b]{2}{*}{ Area } & \multicolumn{3}{|c|}{ Chinook } & \multirow[b]{2}{*}{ Steelhead } & \multirow[b]{2}{*}{ Sturgeon } & \multirow[b]{2}{*}{ Shad } \\
\hline & Lower & Upper & Total & & & \\
\hline CATCH (in numbers) & & & & & & \\
\hline Tongue Point & 0 & 0 & 0 & 3 & 71 & 5 \\
\hline Deep River & 1 & 0 & 1 & 1 & 48 & 2 \\
\hline Blind Ṡlough & 1 & 0 & 1 & 0 & 43 & 0 \\
\hline Steamboat Slough & 5 & 0 & 5 & 6 & 5 & 18 \\
\hline Clifton Channel & 13 & 3 & 16 & 3 & 412 & 7 \\
\hline Cathlamet Channel & 17 & 1 & 18 & 7 & 145 & 17 \\
\hline Wallace Slough & 15 & 1 & 16 & 1 & 1.100 & 13 \\
\hline Total & 52 & 5 & 57 & 21 & 1,824 & 62 \\
\hline \multicolumn{7}{|c|}{ CPUE (Numbers/hour $/ 100 \mathrm{fm}$ ) } \\
\hline Tongue Point & 0.0 & 0.0 & 0.0 & 0.1 & 3.3 & 0.2 \\
\hline Deep River & 0.1 & 0.0 & 0.1 & 0.1 & 4.0 & 0.1 \\
\hline Blind Slough & 0.1 & 0.0 & 0.1 & 0.0 & 2.6 & 0.0 \\
\hline Steamboat Slough & 0.4 & 0.0 & 0.4 & 0.5 & 0.4 & 1.2 \\
\hline Clifton Channel & 0.6 & 0.1 & 0.7 & 0.1 & 17.6 & 0.2 \\
\hline Cathlamet Channel & 0.7 & 0.1 & 0.8 & 0.3 & 6.5 & 0.7 \\
\hline Wallace Slough & $\underline{0.8}$ & $\underline{0.1}$ & $\underline{0.9}$ & $\underline{0.1}$ & $\underline{59.0}$ & 0.7 \\
\hline Total & 0.4 & 0.0 & 0.4 & 0.2 & 13.9 & 0.5 \\
\hline
\end{tabular}


Table 15. Spring terminal test fishery catch, by site and date, 1994.

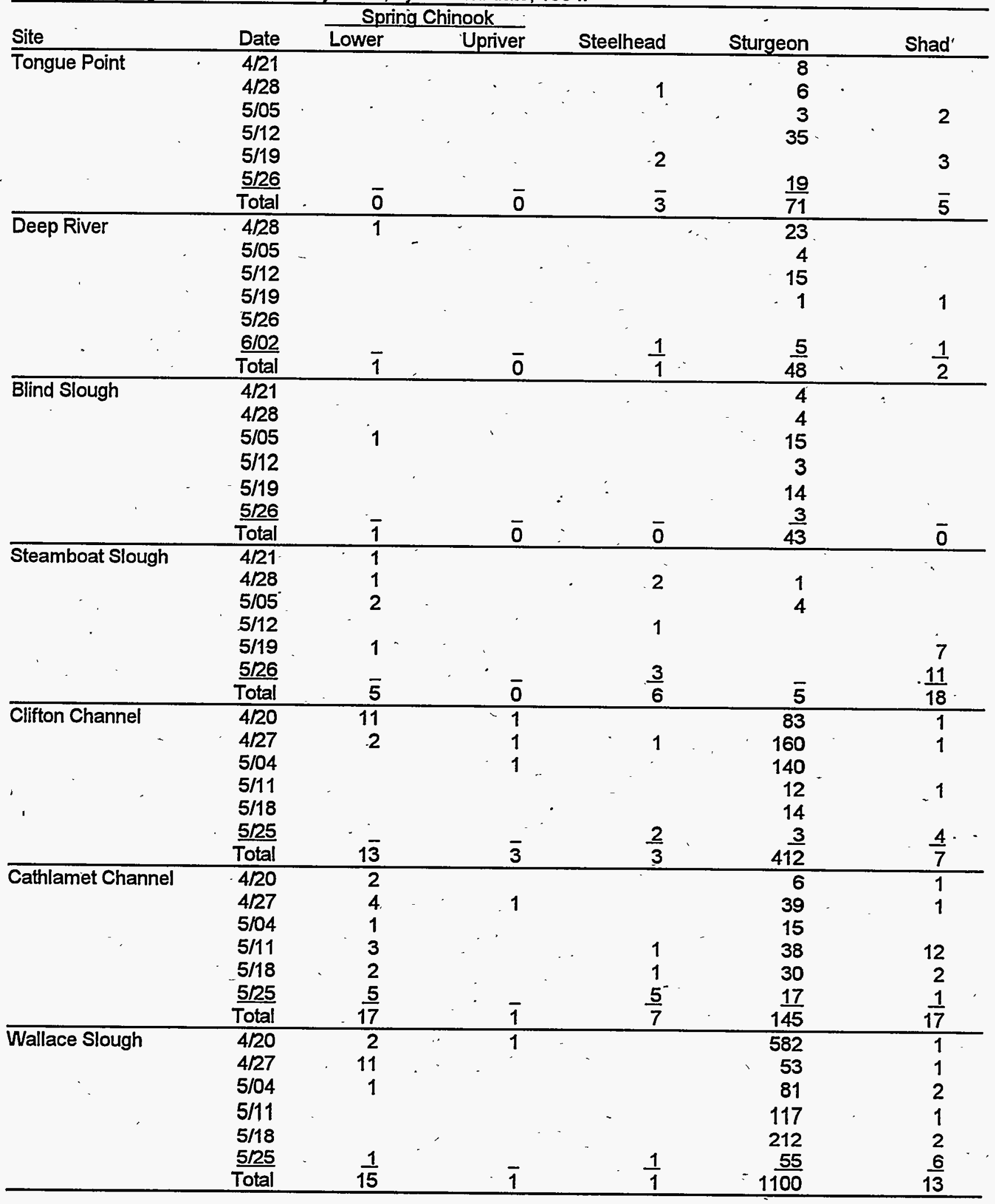


Table 16. Comparative catch and CPUE by mesh size of spring terminal test fishery, 1994.

\begin{tabular}{|c|c|c|c|c|c|c|c|c|c|}
\hline \multirow{2}{*}{ Mesh } & \multirow[b]{2}{*}{ Site } & & \multirow[b]{2}{*}{ Sets } & \multicolumn{3}{|c|}{ Catch } & \multicolumn{3}{|c|}{ CPUE $^{1}$} \\
\hline & & & & Chin & Sthd & Stgn & Chin & Sthd & Stgn \\
\hline \multicolumn{10}{|c|}{ Small Mesh } \\
\hline & Tongue Point & & 7 & 0 & 0 & 23 & 0.0 & 0.0 & 3.2 \\
\hline & Deep River & & 5 & 0 & 1 & 1 & 0.0 & 0.6 & 0.6 \\
\hline & Blind Slough & 1 & 8 & 0 & 0 & 5 & 0.0 & 0.0 & 0.7 \\
\hline & Steamboat Slough & & 11 & 4 & 6 & 5 & 0.4 & 0.6 & 0.5 \\
\hline & Clifton Channel & & 6 & 1 & 3 & 15 & 0.2 & 0.7 & 3.5 \\
\hline & Cathlamet Channel & & 6 & 2 & 4 & 44 & 0.3 & 0.6 & 6.1 \\
\hline & Wallace Slough & & 10 & 11 & 1 & 996 & 0.9 & 0.1 & 83.6 \\
\hline & Total & & 53 & 18 & 15 & 1089 & 0.4 & 0.3 & 21.5 \\
\hline \multicolumn{10}{|c|}{ Large Mesh } \\
\hline & Tongue Point & & 13 & 0 & 3 & 48 & 0.0 & 0.2 & 3.3 \\
\hline & Deep River & . & 12 & 1 & 0 & 47 & 0.1 & 0.0 & 4.5 \\
\hline & Blind Slough & & 10 & 1 & 0 & 38 & 0.1 & 0.0 & 4.1 \\
\hline - & Steamboat Slough & & 7 & 1 & 0 & 0 & 0.4 & 0.0 & 0.0 \\
\hline & Clifton Channel & & 12 & 15 & 0 & 397 & 0.8 & 0.0 & 20.1 \\
\hline & Cathlamet Channel & & 12 & 16 & 3 & 101 & 1.1 & 0.2 . & 6.6 \\
\hline & Wallace Slough & & 9 & $\underline{5}$ & $\underline{\mathbf{0}}$ & 103 & 0.7 & 0.0 & 15.0 \\
\hline & Total & & 75 & 39 & $\overline{6}$ & 734 & 0.5 & 0.1 & 9.0 \\
\hline
\end{tabular}

1 CPUE $=$ Numbers caught/hour/100 fathoms of netting.

Table 17. Comparative day and night catch and CPUE in spring terminal test fishery, 1994.

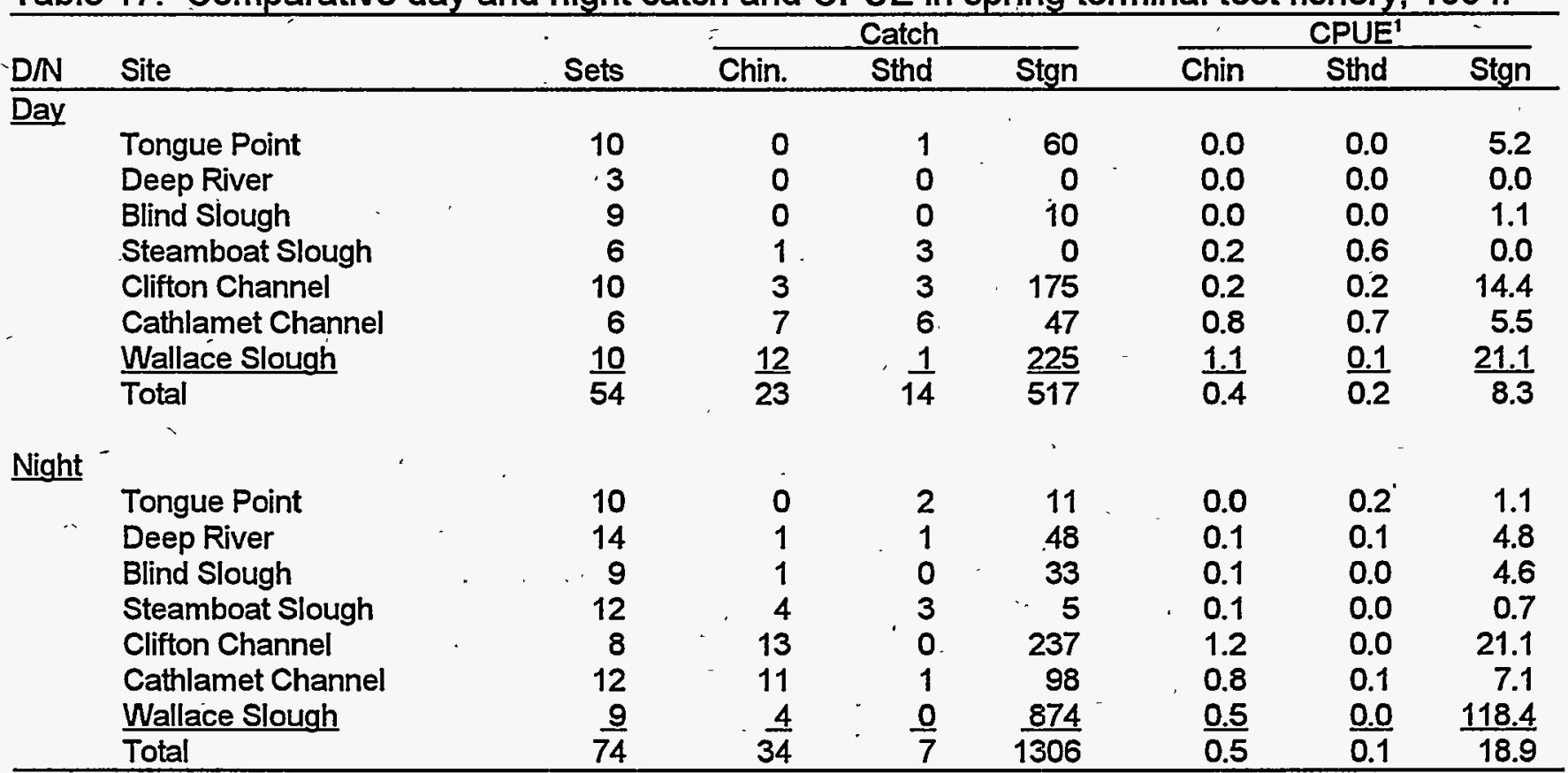

1 CPUE $=$ Numbers caught/hour/100 fathoms of netting. 


\section{B. 1994 Fall Test Fishery in Potential Terminal Fishing Sites}

\section{INTRODUCTION}

Test fisheries were repeated in the seven lower Columbia River terminal areas initially fished in the spring of 1994. Harvest potential in those locations determined to have the best terminal fishery potential will be evaluated continuously throughout the length of the project.

The fall test fishery of the terminal fisheries development project is intended to cover the time period when adult fall chinook and coho are passing through the lower Columbia River. Runs of these species would potentially serve to support terminal fisheries. At this time there is concern for returns of hatchery tule fall chinook, listed Snake River wild fall chinook, and summer steelhead, that may be harvested incidentally in such a fishery. Table 18 lists salmon and steelhead run sizes since 1980. The major intent of the test fishery is to enumerate the impact future terminal fisheries might have on species/runs of concern.

This report is a summarization of data pertinent to this incidental catch monitoring project, including success by area, CWT, age and other biological data. One report alone cannot be considered as a true representation of general conditions in any area. It must be reviewed in the context that it is only part of a multiple-year and multipleseason study.

\section{METHODS}

Four Oregon and three Washington sites were selected based on rearing and harvest criteria established and described under Project Objective \#1. All selected sites were within Columbia River commercial Zone 2. The areas sampled were:

$\begin{array}{lcr}\text { Site } & \text { State } & \frac{\text { River Mile }}{\text { Tongue Point Turning Basin }} \\ \text { OR } & 18 \\ \text { Deep River/Grays Bay } & \text { WA } & 22 \\ \text { Blind Slough } & \text { OR } & 27 \\ \text { Steamboat Slough/Skamokawa } & \text { WA } & 34 \\ \text { Clifton Channel } & \text { OR } & 36 \\ \text { Cathlamet Channel } & \text { WA } & 40 \\ \text { Wallace } & \text { OR } & 49\end{array}$

Fishing was conducted between 21 September through 31 October of 1994 with each site fished weekly for a total of six trips per site, with the exception of the Tongue Point and Deep River sites where weather prevented one week of fishing. 
Each site was fished by a single local gillnetter for all six weeks, with an ODFW or WDFW observer aboard every trip. Fishermen were Joe Parker, Les Clark, Alan Takalo, Art Pedersen, Jack Marincovich and Jim Hogan. Generally, three drift locations were fished at each site weekly in order to spread effort geographically, with fishing conducted during high or low, and daylight or dark, ticles: Each boat distributed effort between small (5-51/2 inch) and large (7-71/2 inch) mesh nets in order to provide a reference of the occurrence of the larger chinook and smaller steelhead. Gear specifications are displayed in Table 19. Generally, each drift of the net was fished for about $1 / 2$ hour, with a day's three drifts being distributed over the change of the high or low tide.

Observations made during the test fishery were: 1) net specifications and fathoms fished, 2) set location, 3) weather, water temperature and turbidity (Secchi disk), 4) layout and pickup times, and 5) catch of all fish species with associated biological data:

Chinook: Data collected with each fish removed from the gillnet include fork length, condition (live or dead), occurrence of mark and/or CWT, skin color, marine mammal damage, and scales removed for aging. Live fish were opercle punched to identify recaptures. If the fish was killed in the net, or CWT, fish weight and sex were recorded, and the snout removed for later CWT removal.

Coho: Data collected were fork length, skin color, fin marks and/or CWT, and marine mammal damage. Live fish were opercle punched to identify recaptures.

Steelhead: Data collected include fork length, race/maturity, fin marks and/or CWT, and marine mammal damage. Scales were taken for ageing and determination of hatchery/wild. All live fish were opercle punched to identify recaptures.

Sturgeon: Each sturgeon caught was sampled for total and fork length, and examined for the occurrence of spaghetti tags or tag scars. Depending on the availability of time, sturgeon over 90 centimeters in total length were single spaghetti tagged and scute marked.

Other species: All other species of fish were enumerated by fishing site, time and gear type.

Water temperature and turbidity readings were taken at each location except when darkness prevented turbidity readings or instruments were not available. The data are presented to compare relative temperature and turbidity at each location for a given week and the change observed through time for each location.

Chinook, coho, steelhead and sturgeon catches at each site were-converted to a 
standardized unit of Catch per Hour per 100 Fathoms of Net to compare catch rates within sites and between sites. Actual fishing time of the gear is difficult to determine since pick time (beginning to end) was highly variable and depended on the amount of gear in the water and number of fish caught. Calculation of fishing time for purposes of this study is defined as:

$$
\frac{\left(S_{E}-S_{B}\right)}{2}+\left(P_{B}-S_{E}\right)+\frac{\left(P_{E}-P_{B}\right)}{2}
$$

Where, $\quad S_{E}=$ Time at end of set,

$S_{B}=$ Time at begin of set,

$P_{E}=$ Time at end of pick,

$P_{B}=$ Time at begin of pick, and

$\left(P_{B}-S_{E}\right) \quad=$ "Soak" time period that the total net is in the water.

\section{RESULTS AND DISCUSSION}

During the six weeks of test fishing over 80 hours of net time was fished. The resulting harvest consisted of nine chinook, 32 coho, one chum salmon, five steelhead, 266 white sturgeon, two green sturgeon, two shad, two squawfish, and one starry flounder (Table 20). With such small numbers, little can be said about resulting patterns other than few salmon and steelhead were caught in all areas, and most sturgeon (83\%) were caught at the two most.upriver sites: Cathlamet Slough and Wallace Slough.

Of the total of nine chinook salmon; one was a jack coming from Wallace Slough on 28 September. No CWTs were recovered from chinook. One chinook salmon was recorded as being a net mortality. Seven chinook came from the three most upriver sites (Clifton Channel, Cathlamet Channel and Wallace Slough). Over time, eight of the nine total came from the first half of the sampling period. Skin color determination showed six bright, one dusky, and two dark ("tule"). The chinook catch was dominated by 4 year olds (seven), which ranged from 73 to 104 centimeters, and averaging 82.9 centimeters, in fork length. The 2-year-old jack measured 44 centimeters, and the only 3-year-old measured 69 centimeters in fork length:

Few coho were caught at all sites, ranging from a maximum of eight at Wallace Slough and a minimum of one in Clifton Channel. Of the total of 32 coho salmon caught, two CWTs were recovered, both at Wallace Slough, one originating from Big Creek Hatchery (7-15-16) and the other from SF Klaskanine Pond (7-59-52). Twelve cohowere recorded as being net mortalities. CPUE on coho was considerably higher (1.1 $\mathrm{fish} / \mathrm{hour} / 100 \mathrm{fm}$ of net) than elsewhere at Deep River/Grays Bay due to the shortness of nets used. Both Tongue Point and Wallace Slough reported the highest of the 
remaining locations ( $0.5 \mathrm{fish} / \mathrm{hour} / 100 \mathrm{fm}$ of net).

The five steelhead were caught at the two most upriver sites (Cathlamet Channel and Wallace Slough), three being net mortalities (see marine mammals comments below). Only three whole bodied steelhead were examined, with all three determined to be summer run and adipose clipped.

Of the total of 268 sturgeon, $222(83 \%)$ came from Wallace Slough and Cathlamet Channel. Both sites each reported a total CPUE of 6.2 sturgeon/hour/100 fathoms of net. Again, short nets used at Grays Bay/Deep River expanded relative CPUE to 3.4 sturgeon/hour/100 fathoms of net. The majority of sturgeon (221 or $82 \%)$ were caught in the first half of the sampling period.

Signs of marine mammals were recorded at Wallace Slough and Cathlamet Channel. Observers noted that a scarred coho was caught at Wallace, while the two steelhead caught in Cathlamet Channel were both severely damaged, with heads being the only portion of the fish recovered.

\section{Catch by Area}

Total catches and catch per unit of effort (CPUE) at each site are displayed in Tables 20 and 21. Sample data, by drift, are totalled in Appendix 3.

Tongue Point (Figure 3): Four drift sites were fished in the same general areas as in the spring program. Boat engine problems necessitated cancellation of the second scheduled fishing day and termination of the contract with Joseph Parker. The remainder of the program was conducted enlisting Les Clark, the Deep River test fisherman. On the first test fishing day, two 210 fathom floater nets were used with $51 . / 2$ inch and 8 inch mesh: On the last four fishing days, two 100 fathom floater nets with $51 / 2$ inch and $71 / 4$ inch mesh were deployed. The total catch was comprised of five coho, two sturgeon, one chum and one shad.

Deep River/Grays Bay (Figure 4): Fishing was conducted at four drift sites: one in Deep River and three in Grays Bay. This is one more site than in the spring, the new location being in the deep waters in the center of Grays Bay where it was expected that more sturgeon could be caught. Two floater nets were fished, with a $51 / 2$ inch and a $71 / 4$ inch mesh. Time was divided fairly evenly between high and low tide. Due to the shallow waters and fishing in narrow waterways, short nets were always used, rarely being over 80 fathoms in length. A total of five coho and 19 sturgeon (including one green sturgeon) were caught. Of that total, one coho and one sturgeon were caught in Deep River, the remainder in Grays Bay. 
Blind Slough (Figure 5): Three drift sites were fished in the same location and manner as in the spring program. The same nets as used in the spring were again employed; 100 fathom floater nets, one with $53 / 4$ inch mesh and the other with $71 / 4$ inch mesh. The total catch, evenly distributed between all sites, consisted of two chinook, two coho, and seven white sturgeon.

Steamboat Slough/Skamokawa (Figure 6): Four drift sites were fished in this area: both ends of the gap between Steamboat Slough and Elochoman Slough, at Skamokawa, and the fourth within Steamboat Slough. The Steamboat Slough and Skamokawa drifts were in narrow waters where no more than 70 fathoms of net were fished. The two gap drifts were fished from shore out into the mainstem, with usually 200 fathoms of net. All drifts but the Skamokawa were fished with both 5 inch and $71 / 2$ inch floater nets. The Skamokawa drift was fished with just a 5 inch mesh net. The five coho and four sturgeon caught were fairly evenly divided between all but the Skamokawa drift, where nothing was caught.

Clifton Channel (Figure 7): Fishing was conducted in the same area and using the same gear as that used during the spring; a 200 fathom $71 / 2$ inch mesh diver net and a 100 fathom $51 / 2$ inch mesh floater net. Each fishing trip two drifts with the diver net on an ebb current were made and a single set with the floater net was fished at either the high or low slack water period. The total catch was comprised of one chinook, one coho, and 14 white sturgeon.

Cathlamet Channel (Figure 8): Fishing was conducted with standard floater gillnets, having either 5 inch or $71 / 2$ inch mesh, and always 200 fathoms in length. Four sites were fished; 1) one at the extreme downstream end of Cathlamet Channel, 2) one in Cathlamet Channel at the upriver end of Elochoman Slough, 3) one directly in front of Cathlamet, and 4) one just above the Cathlamet bridge. The three chinook salmon were all caught at the most downstream site (1), the five coho were distributed fairly evenly between sites, the two steelhead were both caught at the site just below the mouth of the Elochoman slough (2), and 123 sturgeon were caught at all drift sites, with the 51 coming from the most downstream site (1).

Wallace Slough (Figure 9): Fishing was conducted in the same area and using the same gear as fished during the spring; a 150 fathom $53 / 8$ inch mesh floater net and a 150 fathom $71 / 4$ inch mesh floater net. The total of 14 salmonids (three chinook, eight coho, and three steelhead) was the highest for all sites. In addition, 99 white sturgeon and a single shad were caught. The majority of the catch of salmonids and sturgeon were caught during the first three weeks of the 6-week program. 


\section{Catch by Net}

Table 22 compares numbers caught and CPUE for small ( 5 - $51 / 2$ inch) and large ( 7 $71 / 2$ inch) mesh nets, both between areas and for all areas combined. Again, since numbers were small only limited generalizations can be made. In total, the small mesh net tended to catch more fish than the large mesh net at a ratio of about 3:1.

\section{Day and Night}

While slightly more time was fished at daytime (41.4 hours) than at night time (39.2 hours), the majority of the catch came at night time: $89 \%$ of chinook, $69 \%$ of coho and $71 \%$ of sturgeon (Table 23). The exception was in the case of steelhead where all five fish were caught in the daytime. This holds for CPUE on a site-by-site basis, where all sites but one showed better chinook, coho and sturgeon fishing success. Steamboat Slough was the only exception, only on coho.

\section{CONCLUSIONS}

In terms of low catch rates of nontarget species and white sturgeon, Tongue Point, Deep River, Blind Slough, Steamboat Slough, and Clifton Channel show the greatest potential although differences in CPUE between these sites and the uppermost sites of Cathlamet Channel and Wallace Slough are minor.

Use of large and small mesh gear was effective in showing the diversity of species and sizes of fish in the area. As expected, CPUE for white sturgeon and coho were higher for small mesh gear.

Comparison of day and night catches showed higher CPUE during night sets for all species except steelhead.

Background abundance levels of fall chinook and coho appear to be favorably low in all sites, however the fact that 1994 returns to the Columbia River of lower river fall chinook, upriver fall chinook, and coho were at or near record low levels needs to be noted.

\section{RECOMMENDATIONS}

Continue the fall test fishing program using the same methodology as in 1994. 
Table 18. Minimum numbers (in thousands of adults) of lower river and upriver fall chinook, coho, and group B summer steelhead entering the Columbia River, 1980-94.

\begin{tabular}{|c|c|c|c|c|}
\hline \multirow[b]{2}{*}{ Year } & \multicolumn{2}{|c|}{ Fall Chinook } & \multirow[b]{2}{*}{ Coho } & Group B \\
\hline & Lower River & Upriver & & Summer Steelhead \\
\hline 1980 & 159.0 & 166.5 & 299.7 & 43.7 \\
\hline 1981 & 142.9 & 15.4.1 & 170.2 & 37.7 \\
\hline 1982 & 180.8 & 201.6 & 453.2 & 54.3 \\
\hline 1983 & 126.7 & 125.2 & 100.6 & 69.3 \\
\hline 1984 & 136.6. & 185.4 & 414.0 & 126.8 \\
\hline 1985 & 160.0 & 229.0 & 365.7 & 93.6 \\
\hline 1986 & 205.9 & 301.3 & 1527.7 & 101.9 \\
\hline 1987 & 404.3 & 469.2 & 306.4 & 79.8 \\
\hline 1988 & 384.0 & 400.3 & 664.7 & 90.2 \\
\hline 1989 & 217.7 & 328.3 & 701.6 & 117.3 \\
\hline 1990 & 110.7 & 206.6 & 196.2 & 88.7 \\
\hline 1991 & 104.7 & 175.0 & 936.2 & 126.1 \\
\hline 1992 & 100.1 & 125.8 & 210.9 & 143.1 \\
\hline 1993 & 79.8 & 136.8 & 113.5 & 92.8 \\
\hline $1994^{1}$ & 65.7 & 180.8 & 186.1 & 78.4 \\
\hline
\end{tabular}

1 December, 1994 Preliminary Return. Source: WDFW and ODFW, 1994. 
Table 19. Net specifications for 1994 fall terminal test fishery, by site.

\begin{tabular}{|c|c|c|c|c|}
\hline Site & Net Type & Mesh Size & Length & Details \\
\hline Tongue Point & $\begin{array}{l}\text { 1) Floater } \\
\text { 2) Floater } \\
\text { 3) Floater } \\
\text { 4) Floater }\end{array}$ & $\begin{array}{l}51 / 2^{\prime \prime} \\
8^{\prime \prime} \\
51 / 2^{\prime \prime} \\
71 / 4^{\prime \prime}\end{array}$ & $\begin{array}{l}210 \mathrm{fm} \\
210 \mathrm{fm} \\
100 \mathrm{fm} \\
100 \mathrm{fm}\end{array}$ & $\begin{array}{l}14-17 \mathrm{ft} \text {. deep } \\
24 \mathrm{ft} \text {. deep } \\
40 \text { mesh, } 22 \mathrm{ft} \text {. } \\
40 \text { mesh, } 22 \mathrm{ft} .\end{array}$ \\
\hline Deep River & $\begin{array}{l}\text { 1) Floater } \\
\text { 2) Floater }\end{array}$ & $\begin{array}{l}51 / 2 " \\
71 / 4 "\end{array}$ & $\begin{array}{l}100 \mathrm{fm} \\
100 \mathrm{fm}\end{array}$ & $\begin{array}{l}40 \text { mesh, } 22 \mathrm{ft} . \\
40 \text { mesh, } 22 \mathrm{ft} .\end{array}$ \\
\hline Blind Slough & $\begin{array}{l}\text { 1) Floater } \\
\text { 2) Floater }\end{array}$ & $\begin{array}{l}53 / 4^{\prime \prime} \\
71 / 4^{\prime \prime}\end{array}$ & $\begin{array}{l}100 \mathrm{fm} \\
100 \mathrm{fm}\end{array}$ & $\begin{array}{l}15 \mathrm{ft} \text {. deep wl } \\
\text { heavy lead line }\end{array}$ \\
\hline Steamboat Slough & $\begin{array}{l}\text { 1) Floater } \\
\text { 2) Floater } \\
\text { 3) Floater } \\
\text { 4) Floater }\end{array}$ & $\begin{array}{l}5^{\prime \prime} \\
5^{\prime \prime} \\
71 / 2^{\prime \prime} \\
71 / 2^{\prime \prime}\end{array}$ & $\begin{array}{l}60 \mathrm{fm} \\
200 \mathrm{fm} \\
70 \mathrm{fm} \\
200 \mathrm{fm}\end{array}$ & $\begin{array}{l}15 \mathrm{ft} \text {. deep } \\
28 \mathrm{ft} \text {. deep } \\
30 \mathrm{ft} \text { deep } \\
30 \mathrm{ft} \text {. deep }\end{array}$ \\
\hline Clifton Channel & $\begin{array}{l}\text { 1) Floater } \\
\text { 2) Diver }\end{array}$ & $\begin{array}{l}51 / 2^{\prime \prime} \\
71 / 2^{\prime \prime}\end{array}$ & $\begin{array}{l}100 \mathrm{fm} \\
200 \mathrm{fm}\end{array}$ & $\begin{array}{l}16 \mathrm{ft} \text {. deep } \\
12 \mathrm{ft} \text {. deep }\end{array}$ \\
\hline Cathlamet Channel & $\begin{array}{l}\text { 1) Floater } \\
\text { 2) Floater }\end{array}$ & $\begin{array}{l}5^{\prime \prime} \\
71 / 2^{\prime \prime}\end{array}$ & $\begin{array}{l}200 \mathrm{fm} \\
200 \mathrm{fm}\end{array}$ & $\begin{array}{l}28 \mathrm{ft} \text {. deep } \\
30 \mathrm{ft} \text {. deep }\end{array}$ \\
\hline Wallace Slough & $\begin{array}{l}\text { 1) Floater } \\
\text { 2) Floater }\end{array}$ & $\begin{array}{l}53 / 8^{\prime \prime} \\
71 / 4 "\end{array}$ & $\begin{array}{l}150 \mathrm{fm} \\
150 \mathrm{fm}\end{array}$ & $\begin{array}{l}16 \mathrm{ft} \text {. deep } \\
16 \mathrm{ft} \text { deep }\end{array}$ \\
\hline
\end{tabular}


Table 20. Fall terminal test fishery catch and CPUE, by area, 1994.

\begin{tabular}{lccccc}
\hline Area & Chinook & Coho & Steelhead & Sturgeon & Shad \\
\hline CATCH (in numbers) & & & & & \\
\hline Tongue Point & 0 & 5 & 0 & 2 & 1 \\
Deep River & 0 & 6 & 0 & 19 & 0 \\
Blind Slough & 2 & 2 & 0 & 7 & 0 \\
Steamboat Slough & 0 & 5 & 0 & 4 & 0 \\
Clifton Channel & 1 & 1 & 0 & 14 & 0 \\
Cathlamet Channel & 3 & 5 & 2 & 123 & 0 \\
Wallace Slough & $\underline{3}$ & $\underline{8}$ & $\underline{3}$ & $\underline{99}$ & $\frac{1}{2}$ \\
Total & 9 & 32 & 5 & 268 & \\
\hline CPUE (Numbers/hour/100 fm) & 0 & 0.5 & 0 & 0.2 & 0.1 \\
\hline Tongue Point & 0 & 1.1 & 0 & 3.4 & 0 \\
Deep River & 0.1 & 0.1 & 0 & 0.4 & 0 \\
Blind Slough & 0 & 0.4 & 0 & 0.3 & 0 \\
Steamboat Slough & 0.1 & 0.1 & 0. & 0.7 & 0 \\
Clifton Channel & 0.2 & 0.3 & 0.1 & 6.2 & 0 \\
Cathlamet Channel & 0.2 & $\underline{0.5}$ & $\underline{0.2}$ & $\underline{6.2}$ & $\underline{0.1}$ \\
Wallace Slough & $\underline{0.1}$ & 0.3 & 0.0 & 2.6 & 0.0 \\
Total & 0.1 & & & &
\end{tabular}


Table 21. Fall terminal test fishery catch, by site and date, 1994.

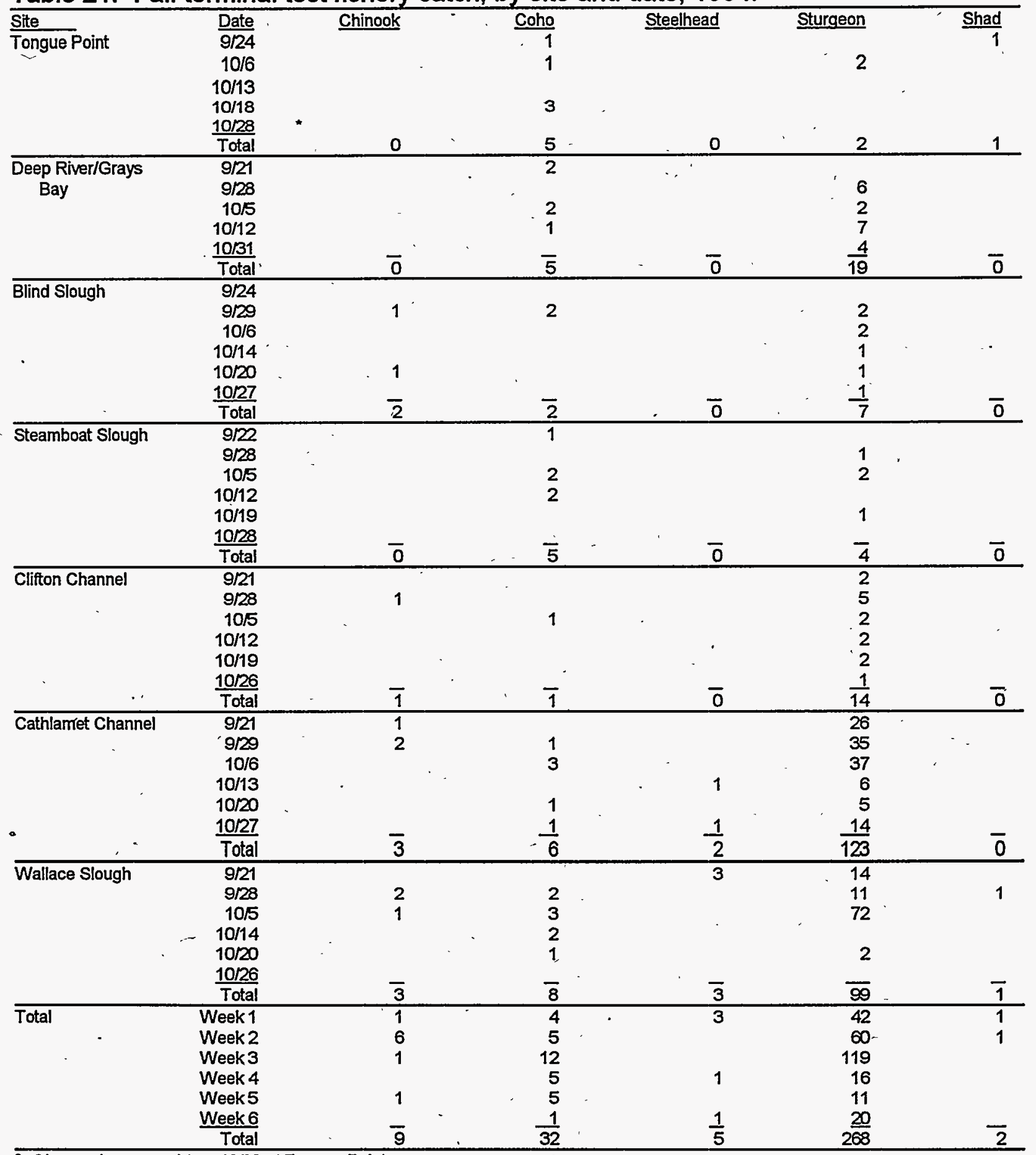

Chum salmon caught on 10/28 at Tongue Point 
Table 22. Comparative catch and CPUE by mesh size of fall terminal test fishery, 1994.

\begin{tabular}{|c|c|c|c|c|c|c|c|c|c|c|}
\hline \multirow[b]{2}{*}{ Mesh } & \multirow[b]{2}{*}{ Site } & \multirow[b]{2}{*}{ Sets } & \multicolumn{4}{|c|}{ Catch } & \multicolumn{4}{|c|}{ CPUE $^{1}$} \\
\hline & & & Chin & Coho & Sthd & Stgn & Chin & Coho & Sthd & Stgn \\
\hline \multicolumn{11}{|c|}{ Small Mesh } \\
\hline & Tongue Point & 7 & 0 & .4 & 0 & 1 & 0 & 0.8 & 0 & 0.2 \\
\hline & Deep River & 9 & 0 & 3 & 0 & 17 & 0 & 0.9 & 0 & 5.2 \\
\hline & Blind Slough & 9 & 1 & 0 & 0 & 2 & 0.1 & 0 & 0 & 0.2 \\
\hline & Steamboat Slough & 11 & 0 & 4 & 0 & 2 & 0 & 0.6 & 0 & 0.3 \\
\hline & Clifton Channel & 7 & 1 & 1 & 0 & 7 & 0.2 & 0.2 & 0 & 1.4 \\
\hline & Cathlamet Channel & 10 & 1 & 3 & 2 & 77 & 0.1 & 0.3 & 0.2 & 6.7 \\
\hline & Wallace Slough. & 13 & 3 & $\underline{8}$ & 1 & 94 & 0.3 & 0.8 & 0.1 & 9.5 \\
\hline & Total & 66 & 6 & 23 & 3 & 200 & 0.1 & 0.5 & $\overline{0.1}$ & 4.0 \\
\hline \multicolumn{11}{|c|}{ Large Mesh } \\
\hline & Tongue Point & 9 & 0. & 1 & 0 & 1 & 0 & 0.2 & 0 & 0.2 \\
\hline & Deep River & 6 & 0 & 3 & 0 & 2 & 0 & 1.4 & 0 & 0.9 \\
\hline & Blind Slough & 9 & 1 & 2 & 0 & 5 & 0.1 & 0.3 & 0 & 0.6 \\
\hline & Steamboat Slough. & 8 & .0 & 1 & 0 & 2 & 0 & 0.2 & 0 & 0.3 \\
\hline & Clifton Channel & 12 & 0 & 0 & 0 & 7 & 0 & 0 & 0 & 0.5 \\
\hline & Cathlamet Channel & 8 & 2 & 2 & 0 & 46 & 0.2 & 0.2 & 0 & 5.4 \\
\hline & Wallace Slough & 6 & $\underline{0}$ & $\underline{0}$ & 2 & 5 & $\underline{0}$ & $\underline{0}$ & $\underline{0.3}$ & $\underline{0.8}$ \\
\hline & Total & $\overline{58}$ & 3 & 9 & 2 & $\overline{68}$ & $\overline{0.1}$ & $\overline{0.2}$ & 0 & 1.3 \\
\hline
\end{tabular}

TPUE = Numbers caught/hour/100 fathoms of netting.

Table 23. Comparative day and night catch and CPUE in fall terminal test fishery, 1994.

\begin{tabular}{|c|c|c|c|c|c|c|c|c|c|c|}
\hline \multirow[b]{2}{*}{$\mathrm{DNN}$} & \multirow[b]{2}{*}{ Site } & \multirow[b]{2}{*}{ Sets } & \multicolumn{4}{|c|}{ Catch } & \multicolumn{4}{|c|}{ CPUE $^{1}$} \\
\hline & & & Chin. & Coho & Sthd & Stgn & Chin & Coho & Sthd & Stgn \\
\hline \multicolumn{11}{|l|}{ Day } \\
\hline & Tongue Point & 10 & 0 & 1 & 0 & 0 & 0 & 0.1 & 0 & 0 \\
\hline & Deep Rive & & 0 & 3 & 0 & 11 & 0 & 0.9 & 0 & 3.3 \\
\hline & Blind Slough & 9 & 0 & 0 & 0 & 2 & 0 & 0 & 0 & 0.3 \\
\hline & Steamboat Slough & 10. & 0 & 3 & $\sigma^{\circ}$ & 0 & 0 & 0.5 & 0 & 0 \\
\hline & Clifton Channel & 9 & 0 & 0 & 0 & 5 & 0 & 0 & 0 & 0.5 \\
\hline & Cathlamet Channel & 9 & 1 & 1 & 2 & 46 & 0.1 & 0.1 & 0.2 & 4.7 \\
\hline & Wallace Slough & 10 & 0 & 2 & 3 & 14 & 0 & 0.3 & 0.4 & 1.9 \\
\hline & Total & 66 & 1. & $\overline{10}$ & 5 & 78 & 0 & $\overline{0.2}$ & $\overline{0.1}$ & 1.5 \\
\hline \multirow{2}{*}{\multicolumn{11}{|c|}{ Night }} \\
\hline & Tongue Point & 6 & 0 & 4 & 0 & 2 & 0 & 1.2 & 0 & 0.6 \\
\hline & Deep Riv & 6 & 0 & 6 & 0 & 19 & 0 & 1.4 & 0 & 3.6 \\
\hline & Blind Slough & 9 & 2 & 2 & 0 & 5 & 0.2 & 0.2 & 0 & 0.6 \\
\hline & Steamboat Slough & 9 & 0 & 2 & 0 & 4 & 0 & 0.2 & 0 & 0.5 \\
\hline & Clifton Channel & 10 & 1 & 1 & 0 & 9 & 0.1 & 0.1 & 0 & 0.9 \\
\hline & Cathlamet Channel & 9 & 2 & 4 & 0 & 77 & 0.2 & 0.4 & 0 & 7.6 \\
\hline & Wallace Slough & 9 & 3 & 6 & $\underline{0}$ & 85 & $\underline{0.3}$ & 0.7 & $\underline{0}$ & 9.7 \\
\hline & Total & $\overline{58}$ & $\overline{8}$ & $\overline{22}$ & 0 & $\overline{190}$ & $\overline{0.2}$ & $\overline{0.4}$ & $\overline{0}$ & $\overline{3.6}$ \\
\hline
\end{tabular}

CPUE $=$ Numbers caught/hour/100 fathoms of netting. 


\section{CHAPTER.5. SUITABILITY OF VARIOUS ANADROMOUS FISH STOCKS FOR USE IN TERMINAL FISHERIES}

\section{A. Native Stocks and Compatibility Issues}

\section{Policy Issues}

In selecting suitable salmonid stocks for use in terminal fishing sites, it is important to consider the status and potential impacts to native fish stocks. Wild fish management policies for the states of Washington and Oregon have been developed only within recent years. In 1990 ODFW adopted the Wild Fish Management Policy. General policies of wild fish management are stated in the Oregon Administrative Rules (OAR) 635-07-526 (1) Protection of genetic resources shall be the priority in the management of wild fish to assure optimum economic, commercial, recreational, and aesthetic benefits for present and future residents of Oregon.

In August 1993, WDFW began developing a Wild Salmonid Policy which has evolved from a "Scoping Discussion Draft" to an "In Progress Working Draft" (July, 1995). This draft wild salmonid policy states, "Protect, restore, and enhance the productivity, production, and diversity of wild salmonids and their ecosystems to sustain ceremonial, subsistence, commercial, and recreational fisheries; nonconsumptive fish benefits; and related cultural and ecological values." The WDFW wild salmonid policy is presently being developed as is the implementation of the policy. At this time the best information on the status of naturally spawning salmonid populations for Washington Columbia River stocks is compiled in "1992 Washington State Salmon and Steelhead Stock Inventory, Appendix Three, Columbia River Stocks."

To consolidate and summarize the status of native naturally spawning salmonid stocks in Oregon and Washington tributaries below Bonneville Dam Tables 24 and 25 were constructed. In Oregon, only three native stocks of salmonids (Sandy River fall chinook, Clackamas River/Lower Willamette River coho, and Sandy River/coastal winter steelhead) are considered stable. Most stocks are depicted as declining, small, or very small. Some populations of lower Columbia fall chinook, lower Columbia River coho, and chum may be extinct. In Washington, four native stocks of salmonids (Lewis River fall chinook, Hardy Creek fall chum, Kalama River winter steelhead, and South Fork Toutle River winter steelhead) are considered healthy and stable. The remaining native stocks are depressed (14) or unknown (six).

Since the majority of native salmonid stock populations of the Lower Columbia River are not in the stable and healthy category, we must exercise good judgement in selecting stocks for use in terminal areas to avoid or minimize detrimental interactions 
Table 24. Status of Oregon native salmonid stocks below Bonneville Dam. ${ }^{1}$

\begin{tabular}{|c|c|c|c|c|c|c|}
\hline Species & Race & Stock & Stock Status & $\begin{array}{l}\text { Return } \\
\text { Timing } \\
\end{array}$ & $\begin{array}{l}\text { Spawnining } \\
\text { Timing }\end{array}$ & $\begin{array}{l}\text { Location of Self- } \\
\text { Sustaining Populations }\end{array}$ \\
\hline Chinook & Fall & L. Col. R. & $\begin{array}{l}\text { Very Small, Some } \\
\text { Extinct }\end{array}$ & Aug.-Sep. & Sep.-Oct. & Unknown \\
\hline & Fall & Sandy R. & $\begin{array}{l}\text { Stable (1000 - "A } \\
\text { Few" Thousand) }\end{array}$ & Oct. & Nov.-Jan. & Sandy River \\
\hline & $\begin{array}{l}\text { Spring } \\
\text { Spring }\end{array}$ & $\begin{array}{l}\text { Willamette } \\
\text { Sandy }\end{array}$ & $\begin{array}{l}\text { Very Small } \\
\text { Very Small }\end{array}$ & $\begin{array}{l}\text { Feb.-May } \\
\text { Feb.-May }\end{array}$ & $\begin{array}{l}\text { Sep. } \\
\text { Sep. }\end{array}$ & $\begin{array}{l}\text { McKenzie \& Clackamas R. } \\
\text { Sandy River }\end{array}$ \\
\hline Coho & & $\begin{array}{l}\text { L. Col. R. } \\
\text { L. Will. R. }\end{array}$ & $\begin{array}{l}\text { Very Small, Some Extinct } \\
\text { Stable (500 - "A Few" } \\
\text { Thousand) }\end{array}$ & Nov.-Jan. & $\begin{array}{l}\text { Nov.-Dec. } \\
\text { Dec.-Jan. }\end{array}$ & $\begin{array}{l}\text { Dec.-Jan. Unknown } \\
\text { Clackamas River }\end{array}$ \\
\hline & & Clatskanie R. & Very Small & Nov.-Dec. & Dec.-Jan. & Clatskanie River \\
\hline Chum & & L. Col. R. & May Be Extinct & Oct. & Nov. & Unknown \\
\hline Steelhead & $\begin{array}{l}\text { Winter } \\
\text { Winter }\end{array}$ & $\begin{array}{l}\text { Coastal } \\
\text { Coastal }\end{array}$ & $\begin{array}{l}\text { Stable }(>1,000) \\
\text { Declining }\end{array}$ & $\begin{array}{l}\text { Dec.-Apr. } \\
\text { Dec.-Apr. }\end{array}$ & $\begin{array}{l}\text { Mar.-May } \\
\text { Mar.-May. }\end{array}$ & $\begin{array}{l}\text { Sandy River } \\
\text { Willamette Tributaries } \\
\text { up to Calaponia R. }\end{array}$ \\
\hline & $\begin{array}{l}\text { Winter } \\
\text { Winter }\end{array}$ & $\begin{array}{l}\text { Coastal } \\
\text { Coastal }\end{array}$ & $\begin{array}{l}\text { Declining }(>1,000) \\
\text { Small }\end{array}$ & $\begin{array}{l}\text { Dec.-Apr. } \\
\text { Dec.-Apr. }\end{array}$ & $\begin{array}{l}\text { Mar.-May } \\
\text { Mar.-May }\end{array}$ & $\begin{array}{l}\text { Clackamas River } \\
\text { L. Col. R. Small Basins }\end{array}$ \\
\hline Cutthroat & Coastal & L. Col. R. & $\begin{array}{l}\text { Extremely low, declining, } \\
\text { state sensitive species }\end{array}$ & & Jul.-Nov.. & Feb.-May \\
\hline
\end{tabular}

1 This table assembled using information from "1994 Biennial Report on the Status of Wild Fish in Oregon and the Implementation of Fish Conservation Policies", ODFW, Feb. 1994. 
Table 25. Status of Washington native salmonid stocks below Bonneville Dam. ${ }^{1}$

\begin{tabular}{|c|c|c|c|c|c|c|}
\hline Species & Race & Stock . & Stock Status & $\begin{array}{l}\text { Return } \\
\text { Timing }\end{array}$ & $\begin{array}{l}\text { Spawning } \\
\text { Timing } \\
\end{array}$ & $\begin{array}{l}\text { Location of Self- } \\
\text { Sustaining Populations }\end{array}$ \\
\hline Chinook & Fall & LRW & $\begin{array}{l}\text { Average }=13,000 \text { fish } \\
\text { Stable, Healthy }\end{array}$ & Aug.-Nov. & Oct.-Dec. & Lewis River \\
\hline Chum & $\begin{array}{l}\text { Fall } \\
\text { Fall } \\
\text { Fall }\end{array}$ & $\begin{array}{l}\text { Grays R. } \\
\text { Hardy } \mathrm{Cr} \text {. } \\
\text { Hamilton } \mathrm{Cr} \text {. }\end{array}$ & $\begin{array}{l}\text { Depressed } \\
\text { Healthy - Stable } \\
\text { Depressed, Declining }\end{array}$ & $\begin{array}{l}\text { Oct.-Nov } \\
\text { Oct. } \\
\text { Oct. }\end{array}$ & $\begin{array}{l}\text { Nov.-Dec. } \\
\text { Nov.-Dec. } \\
\text { Nov.-Dec. }\end{array}$ & $\begin{array}{l}\text { Grays River } \\
\text { Hardy Creek } \\
\text { Hamilton Creek }\end{array}$ \\
\hline Steelhead & Winter & L. Col. R. & $\begin{array}{l}\text { Kalama \& S:F. Toutle Healthy } \\
4 \text { Streams Small \& Unknown } \\
\text { Remaining Streams Depressed }\end{array}$ & Dec.-Apr. & Mar.-May & 17 L. Col. R. Tributaries \\
\hline & Summer & $\begin{array}{l}\text { Lewis R. } \\
\text { Washougal }\end{array}$ & $\begin{array}{l}\text { N.F. Lewis Depressed } \\
\text { E.F. Lewis Unknown } \\
\text { Unknown }\end{array}$ & $\begin{array}{l}\text { May-Nov. } \\
\text { May-Nov. }\end{array}$ & $\begin{array}{l}\text { Mar.-May } \\
\text { Mar.-May }\end{array}$ & $\begin{array}{l}\text { N.F. Lewis River } \\
\text { E.F. Lewis River } \\
\text { Washougal and } \\
\text { W.F. Washougal }\end{array}$ \\
\hline
\end{tabular}

1 This table was assembled from information in "1992 Washington State Salmon and Steelhead Stock Inventory, Appendix Three, Columbia River Stocks", Washington Department of Fisheries and Washington Department of Wildlife, June 1993. 
with native populations. Examples of detrimental interactions are hybridization resulting from straying, competition for habitat, predation, and disease.

\section{Economic Value of Hatchery Stocks}

A comprehensive analysis of economic value and benefits for potential stocks for use in terminal fisheries will be addressed in a terminal fisheries business plan prepared by Hans Radtke, economist contracted by SFA and funded by BPA. The "Business Plan" is scheduled for completion in fall, 1995.

For Columbia River commercially caught salmon the ex-vessel price is a measure of relative value of the stocks considered. Average ex-vessel value for all grades of each stock are estimated based on historic prices. Expected ex-vessel price for coho is $\$ 0.90$ per pound, $\$ 1.50$ per pound for URB and RRB fall chinook, $\$ 0.30$ per pound for LRH tule fall chinook, and $\$ 2.50$ per pound for spring chinook.

Recreational catch value cannot be evaluated based on market value but in terms of income impact per recreational fishing day.

\section{B. Availability and Suitability of Hatchery Fish}

\section{INTRODUCTION}

To address the question of suitability and availability of hatchery salmon stocks for use in terminal fisheries requires evaluation of biological characteristics, economic considerations, ecological impacts, political issues, and allocation issues from the local to international levels. In this chapter we will limit discussion of stock availability to those salmon stocks presently produced in hatchery programs in the lower Columbia River below Bonneville Dam. A discussion on stock suitability will focus on how biological, economic, and ecological factors need to be evaluated in aggregate for each specific terminal site. The product of this exercise is a list of potential stocks for use in terminal fishery sites. Also in this chapter the process of securing approval for new production in terminal areas will be discussed.

Presently, securing hatchery salmon juveniles for experimental and production . purposes in the Youngs Bay terminal fisheries program has already exposed agency managers to the subject of stock availability and suitability. Valuable knowledge has been gained from initial experiments in Youngs Bay that will aid in stock selection. 


\section{RESULTS AND DISCUSSION}

\section{Stock Suitability}

Table 26 shows primary biological characteristics for the major salmon stocks presently in production at Oregon and Washington lower Columbia River hatcheries. Smolt age and time of year when outmigration occurs is a characteristic that would affect the time frame required for hatchery rearing and net pen rearing. Age of fish upon return determines not only average size of adults, but exposure through time to fisheries. Average weight of adults at return can determine commercial marketability and recreational sport interest level. Peak adult migration period into freshwater will affect timing for harvest opportunities and commercial market opportunities. Spawning timeframe is important when assessing the potential for strays to hybridize with natural spawning populations. Origin of the stock is important when addressing the potential risk of native stocks of genetic damage. Three coho stocks, three fall chinook stocks, and two spring chinook stocks were chosen as the most available in terms of abundance.

Early stock coho are raised by both state and federal hatcheries primarily in the lower Columbia River below Bonneville Dam. Early stock coho in Washington are derived from the Toutle River stock while in Oregon the early stock are presently a mixed blend of Toutle and Oregon lower Columbia stocks resulting in a local mix as an outcome of egg transfers between stations. An exception to the homogeneous stock for Oregon is the Sandy River coho stock which exhibit a slightly later entry into freshwater and a slightly later spawning timing. The aggregate early stock has a southerly ocean migration pattern.

Late stock coho are produced solely by WDFW hatcheries primarily below Bonneville Dam. The stock origin is from the Cowlitz River. Ocean distribution is more northerly off the Washington coast. Late stock coho return to freshwater later than early stock with little overlap in migration and spawning timing.

Fall chinook stocks are the LRH tule stock, RRB stock, and the URB stock. As smolts all three stocks migrate as subyearlings however LRH smolts are released in the spring at a smaller size while RRB and URB smolts are released in the late spring-early summer period at a larger size. LRH and RRB stocks are primarily 3- and 4-year-olds at return while URBs have more 5-year-olds returning as adults. This slight difference in age composition at return for URBs is reflected in a large average size at return. Migration timing for adults entering freshwater is very similar for all three stocks, however peak spawning times differ dramatically; LRH spawn soon after entering freshwater, followed by RRBs, and lastly URBs. The origin of these three hatchery stocks also differ significantly. The LRH tules originated from native stocks in the lower Columbia tributaries, while the URB stock at Bonneville Hatchery was developed from 
Table 26. Biological characteristics of hatchery salmon stocks considered for potential use in lower Columbia River terminal fisheries.

\begin{tabular}{llclll}
\hline Hatchery & Smolt & $\begin{array}{c}\text { Predominant } \\
\text { Adult Age }\end{array}$ & $\begin{array}{c}\text { Average Adult } \\
\text { Size at }\end{array}$ & Peak Time & Stock \\
Stock & Time-Age & at Return Return (pounds) & Migration Spawning & Origin \\
\hline
\end{tabular}

Coho

\begin{tabular}{|c|c|c|c|c|c|c|}
\hline Early & Spr. Yearling & 3 & 7 & Aug.-Sep. & Oct.-Nov. & $\begin{array}{c}\text { WA Toutle R. } \\
\text { OR Lower } \\
\text { Col.R. Tribs. }\end{array}$ \\
\hline Late & Spr. Yearling & 3 & 7 & Oct.-Nov. & Nov.-Jan. & WA Cowlitz R. \\
\hline
\end{tabular}

Fall Chinook

$\begin{array}{ccccccc}\text { LRH } & \begin{array}{c}\text { Spr. Subyearling } \\ :\end{array} & 38: 4 & 17 & \text { Aug.-Sep. Sep.-Oct. } & \begin{array}{c}\text { OR-WA } \\ \text { Lower Col.R. }\end{array} \\ \text { RRB } & \text { Sum. Subyearling } & 38: 4 & 17 & \text { Aug.-Sep. Oct.-Nov. } & \begin{array}{c}\text { OR } \\ \text { Rogue R. }\end{array} \\ \text { URB } & \text { Sum. Subyearling } & 3,485 & 20 & \text { Aug.-Sep. Nov.-Dec. } & \begin{array}{c}\text { Upper Col.R. } \\ \text { Mainstem }\end{array}\end{array}$

Spring Chinook

\begin{tabular}{llcccccc} 
Willamette & Spr. Yearling : & 48.5 & 15 & Feb.-May & Sep. & $\begin{array}{c}\text { OR } \\
\text { Willamette R. }\end{array}$ \\
Cowlitz & Spr. Yearling & 48.5 & 15 & Mar.-May & Sep. & $\begin{array}{c}\text { WA } \\
\text { Cowlitz R. }\end{array}$ \\
\hline
\end{tabular}


wild bright fall chinook trapped at Bonneville Dam. The RRB stock at Big Creek Hatchery originates from the native Rogue River fall chinook population on the Oregon coast. Ocean distribution patterns also differs from each stock. The URB stock is the most northerly in distribution ranging to Alaska. The LRH stock migrate up to British Columbia while the RRB stock migrates primarily south off Oregon. Each stock is genetically distinct from the other.

The two spring chinook stocks, Willamette and Cowlit, exhibit far more similar characteristics than fall chinook. Both stocks migrate as yearling smolts in the spring, mature as 4- and 5-year-olds, attain a similar adult size at maturity, and reach spawning maturity at about the same time. A slightly earlier timing into the Columbia River is noted for Willamette spring chinook however. Both stocks migrate northward from the mouth of the Columbia with Willamette stocks found slightly more northerly. Genetically distinct, each stock is named for the river system of origin.

Table 27. shows estimated survival rates for the same hatchery stocks listed in Table 26. Recent brood years were chosen to best represent expected average survival documented. Expected survival of net pen releases is based on results of recent experiments in Youngs Bay with early stock coho and RRB fall chinook. No other information is available for other stocks listed. A survival advantage factor of 2.33 calculated for Oregon early stock coho was applied for Washington early and Cowlitz stock coho and the calculated value of 1.77 for RRB fall chinook was applied to LRH and URB fall chinook and Willamette and Cowlitz spring chinook. Percent survivors to the Columbia is the reciprocal of the ocean harvest rate and is important to show the effect of ocean harvest on returns to the Columbia. The survival to Columbia River fisheries is distributed between in-river sport and terminal commercial fisheries with no hatchery return anticipated.

Coho survival rates are expected to average between $4.80 \%$ and $8.39 \%$ for smolts released from terminal net pen rearing sites. If ocean harvest rates are similar to recent years (1991 and 1992) at about $48 \%$ for these stocks, survival to Columbia River fisheries will average between $2.49 \%$ and $4.34 \%$ and terminal commercial fisheries harvest comprising about $80 \%(1.99 \%-3.47 \%)$ of the estimated return to the Columbia River mouth.

Fall chinook survival rates are as varied as their biological characterizations. The LRH stock survival rates are the poorest with only $0.74 \%$ survival for hatchery and $1.30 \%$ for net pen programs. Survival to Columbia River is estimated to be only $0.56 \%$ with only $0.34 \%$ projected for terminal commercial fisheries. The RRB stock is estimated to have the highest total survival rate $(4.44 \%)$, however since this stock can be exposed to a high ocean exploitation rate (nearly $70 \%$ ), only $1.35 \%$ are expected to survive to enter the Columbia River. In addition, a high estuary sport harvest rate for this stock occurs (about $40 \%$ ) resulting in only $0.81 \%$ projected to contribute to terminal commercial 
fisheries. The URB stock survival rate from net pen releases is estimated to be $3.42 \%$. An ocean harvest rate of only $40 \%$ results in $2.06 \%$ survival to the Columbia River with $1.85 \%$ projected to be harvested in terminal commercial fisheries (about $90 \%$ of thereturn to the Columbia River).

Willamette and Cowlitz stock spring chinook survival rates from hatchery releases of $1.22 \%$ and $2.25 \%$ are within the range of survival rates for the fall chinook stocks (0.74\%-2.51\%). Similarly, estimated survival rates for net pen released spring chinook are within the range for fall chinook. The lowest ocean harvest rates for all salmon . stocks considered is about $18 \%$ for Willamette stock spring chinook, while Cowlitz spring chinook are subjected to an ocean rate of about $53 \%$, similar to the LRH fall chinook stock. Resultant survival rates to the Columbia River mouth are $2.30 \%$ and $1.89 \%$ for Willamette and Cowlitz stocks. With an estimated $95 \%$ of the return to the Columbia River projected to be harvested in terminal commercial fisheries, survival rates of $2.19 \%$ Willamette stock and $1.80 \%$ Cowlitz stock are expected.

\section{New production and application to terminal fisheries}

Availability of hatchery production for use in terminal fisheries and the role of hatchery production relating to harvest allocation obligations is a very important factor in development of successful terminal fisheries. New production needs to be defined with emphasis on optimizing the use of present hatchery capacity while keeping within the aggregate annual smolt production ceiling of 197.4 million smolts for the Columbia River Basin established by the NMFS proposed recovery plan. "Nearly 100 artificial production facilities produce $\mathbf{1 7 0}$ million to $\mathbf{2 0 0}$ million smolts annually in the Columbia River Basin. Approximately $75 \%$ of the Columbia River Basin salmon and steelhead adults are produced in hatcheries. The purpose of these facilities is to mitigate for losses of salmon and steelhead production resulting from dams and other developments." (NPPC, 1992). A substantial portion of salmon production at hatcheries is dedicated to harvest mitigation. "These priorities are developed by the fisheries co-managers to meet specific fish management objectives, such as mixedstock or terminal-area fisheries, supplementation of weak stocks, or in-river recreational or net fisheries (BPA, 1994).

Development of terminal fisheries will require changes in hatchery production goals. Obligating significant portions of hatchery production for release in terminal locations where harvest potential is greatest while maintaining sufficient escapement for brood stock is a solution for maintaining traditional in-river harvest rates and reducing hatchery surpluses with anticipated reductions in traditional Columbia River mainstem harvest opportunities. Hatchery yearling smolt production could be increased if net pen rearing programs are utilized for an over-winter period (fall-spring).

A simplified example of increasing smolt production would be for a coho hatchery 
Table 27. Estimated survival rates (percent) for hatchery salmon stocks considered for potential use in Lower Columbia River terminal fisheries.

\begin{tabular}{|c|c|c|c|c|c|c|c|}
\hline \multirow[b]{2}{*}{$\begin{array}{l}\text { Hatchery } \\
\text { Stock }\end{array}$} & \multirow[b]{2}{*}{ Broods } & \multicolumn{2}{|c|}{ Survival Rates $^{1}$} & \multirow{2}{*}{$\begin{array}{r}1 \text { - Ocean } \\
\text { Harvest } \\
\text { Rate }^{2}\end{array}$} & \multicolumn{3}{|c|}{ Col. R. Fisheries ${ }^{3}$} \\
\hline & & $\begin{array}{l}\text { On-Station } \\
\text { Release }\end{array}$ & $\begin{array}{l}\text { Net Pen } \\
\text { Release }\end{array}$ & & $\begin{array}{l}\text { Estuary \& } \\
\text { F.W. Sport C }\end{array}$ & $\begin{array}{l}\text { Terminal } \\
\text { ommercial }\end{array}$ & Total \\
\hline
\end{tabular}

$\underline{\mathrm{COHO}}$

$\begin{array}{llllllll}\text { OR Early } & ' 88-' 89 & 3.21 & 7.48 & 51.7 & 0.77 & 3.09 & 3.86 \\ \text { WA Early } & ' 88-' 89 & 2.06 & 4.80 & 51.7 & 0.50 & 1.99 & 2.49 \\ \text { WA Cowlitz } & \text { ' } 88-' 89 & 3.60 & 8.39 & 51.7 & 0.87 & 3.47 & 4.34\end{array}$

FALL CHINOOK

$\begin{array}{llllllll}\text { OR LRH } & \text { '83-'87 } & 0.74 & 1.30 & 43.1 & 0.22 & 0.34 & 0.56 \\ \text { OR RRB } & \text { ' } 83-' 87 & 2.51 & 4.44 & 30.5 & 0.54 & 0.81 & 1.35 \\ \text { OR URB } & ' 83-' 87 & 1.93 & 3.42 & 60.2 & 0.21 & 1.85 & 2.06\end{array}$

SPRING CHINOOK

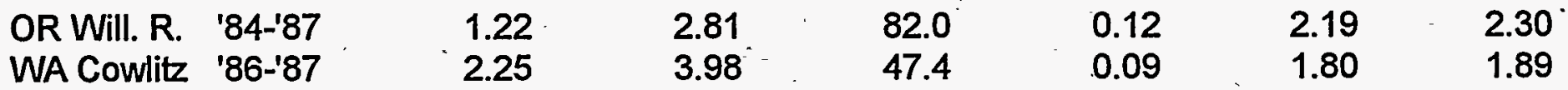

1 For Oregon hatchery stocks survival rates for selective broods released on station were taken from "Annual Coded Wire Tag Program Missing Production Groups", Annual Report, 1993. Garrison, R.L., et al. Oregon Department of Fish and Wildlife. April 1994. Survival rates for Washington Cowlitz coho and spring chinook are from "Annual Coded Wire Tag Program (Washington) Missing Production Groups", Annual Report, 1994. Fuss, et al. Washington Department of Fisheries. December, 1994. Documentation of estimated survival rates for net pen releases are based on survival advantage shown for Youngs Bay net pen early coho and RRB fall chinook. In the absence of other stock specific data, the survival advantage for early coho was used for Cowlitz coho and the survival advantage for RRB fall chinook was applied to LRH tule, URB, Willamette spring chinook, and Cowlitz spring chinook to estimate the survival rates of net pen releases. See Appendix 4.

2 Same source as footnote 1. For Washington coho stocks, however the data for Oregon early stock coho is used. Ocean harvest rate exclusive of estuary Buoy 10 harvest is not easily accessible for Washington coho. 'Predictive data base for Oregon Production Index (OPI). coho uses the same ocean harvest rates for all OPI coho stocks.

${ }^{3}$ Apportionment of survival to Columbia River fisheries is based on data in "Potential Lower Columbia River Terminal Salmon Fisheries" Interim Report - July 1994, Stephen Smith, et al. 
operating at a one million smolt release capacity to utilize available rearing space through the fall to accommodate rearing an additional group. If an additional 300,000 fingerling coho are reared through the fall and then trucked to terminal sites the production capacity utilizing the satellite net pen sites could be increased to 1.3 million. In addition, if traditional Columbia River harvest opportunities are reduced because of constraints related to listed species.under the ESA, a reduction in smolts released at the hatchery to a level to accommodate brood stock and tributary harvest needs could occur that will minimize hatchery surpluses. If 500,000 smolts can satisfy this need, then the remaining 500,000 smolts could be available for use in terminal areas for short-term acclimation. In this simplistic scenario, a hatchery with a traditional one million smolt program goal could increase the total production to 1.3 million, reduce the on-station release to 500,000 , and provide 800,000 smolts for terminal areas. Nearly all of the adults returning to terminal areas could then be harvested. If hatchery production programs do not include terminal area release strategies, large surpluses could occur in most years.

To evaluate new artificial production projects the NPPC calls for detailed master plans where there is not a National Environmental Policy Act (NEPA) document. A final Environmental Assessment (EA) for the Youngs Bay salmon rearing and release program was completed by the BPA in April, 1993, to meet the requirements of NEPA. A Finding of No Significant Impact (FONSI) was issued by the U.S. Department of Energy (DOE) for the Youngs Bay program. For the Lower Columbia River Terminal Fisheries Research Project an EA has been completed with a FONSI issued by DOE (May, 1995).

New production for use in terminal fisheries must be included in the aggregate annual smolt production ceiling for the Columbia River basin of 197.4 million as specified in the NMFS proposed recovery plan (Table 28). Furthermore, use of production from Mitchell Act funded public hatcheries require the approval of NMFS. Additionally, the Production Advisory Committee (PAC) established by the US v Oregon Columbia River Fish Management Plan must be informed to assure compliance and that allocation obligations are met. Lastly, the policies and procedures of the Integrated Hatchery Operations Team (IHOT) will be applied to new production at terminal facilities. IHOT was created in response to a need identified in the Strategy for Salmon (NPPC, 1992). 
Table 28. Annual smolt production ceiling for unlisted species in the Columbia River Basin established in NMFS proposed recovery plan, March 1995.

\begin{tabular}{|c|c|c|c|c|c|c|c|c|}
\hline Agency & Spring Chinook & Fall Chinook & Coho & Steelhead & Chum & Sockeye & $\begin{array}{l}\text { Sea-Run } \\
\text { Cutthroat }\end{array}$ & Total \\
\hline \multicolumn{9}{|l|}{ Snake River } \\
\hline BPA & 454,700 & $\because$ & & & & & & 454,700 \\
\hline COE & & & , & $2,300,000$ & & & & $2,300,000$ \\
\hline USFWS & $5,532,816$ & 800,000 & · & $6,351,000$ & & & - & $12,683,816$ \\
\hline IDFG & $3,000,000$ & & & $1,800,000$ & & & & $4,80,0,000$ \\
\hline Snake R. Total & $8,987,516$ & 800,000 & & $10,451,000$ & & & $\cdot$ & $20,238,516$ \\
\hline \multicolumn{9}{|l|}{ Non-Snake River } \\
\hline SFWS & $3,975,000$ & . & & 400,000 & & . & & $4,375,000$ \\
\hline NMFS & $10,241,700$ & $75,984,750$ & $21,836,000$ & $2,434,250$ & & $\cdot$ & 126,975 & $110,623,675$ \\
\hline \multirow[t]{5}{*}{ - } & $6,968,000$ & $10,380,000$ & , & 507,500 & & & & $17,855,500$ \\
\hline & $1,290,000$ & $2,700,000$ & & 150,000 & & & . & $4,140,000$ \\
\hline & & $\therefore$ & & . & & 150,000 & . & 150,000 \\
\hline & 800,000 & 900,000 & $2,868,450$ & 729,250 & . & & 15,000 & $5,312,700$ \\
\hline & $7,014,500$ & $14,909,500$ & $9,700,200$ & $2,435,000$ & 300,000 & 240,000 & 145,000 & $34,744,200$ \\
\hline Non-Snake R. Total & $30,289,200$ & $104,874,250$ & $34,404,650$ & $6,656,000$ & 300,000 & 390,000 & 286,975 & $177,201,075$ \\
\hline Basin Total & $39,276,716$ & $105,674,250$ & $34,404,650$ & $17,107,000$ & 300,000 & 390,000 & 286,975 & $197,439,591$ \\
\hline
\end{tabular}




\section{CHAPTER 6. COST AND LOGISTICS OF A LARGE SCALE REARING AND RELEASE PROGRAM FOR POTENTIAL TERMINAL FISHING SITES}

\section{A. Production Capability by Site}

From a total list of 25 potential sites, the list was reduced through a ranking of rearing and harvest criteria (Chapter 1, Selection of Terminal Fishery Sites). The seven highest priority sites are being further evaluated for rearing and harvest potential.

\section{Tongue Point (Oregon)}

The Tongue Point site has the highest potential rearing area and depth of all sites considered. The northern-most pier, owned by the U.S. Department of Labor, and about 1,000 feed long can accommodate many rearing pens. This rearing site should have flow and velocity needed to maintain water quality. Water exchange comes primarily through tidal flushing, with some fresh water from the John Day River. Freshwater from this source may be beneficial in attracting adults back to the harvest area. This rearing site has excellent access; about a mile from Highway 30 . The site can be accessed by truck right up to the pens via the pier. Minimal site improvements are needed.

Pens 150-200 Species/Numbers

Spring Chinook: 3-4 million smolts, November to February rearing. Spring Chinook: 3-4 million smolts, March acclimation (two weeks).

Coho: 3-4 million smolts, April 1-15 acclimation.

Coho: 3-4 million smolts, April 15-30 acclimation.

Coho: 3-4 million smolts, May 1-15 acclimation.

Coho: 3-4 million smolts, May 15-30 acclimation.

Fall Chinook: 4.5-6 million, June-August rearing (URB, RRB).

$\begin{array}{lc}\text { Spring Chinook } & \text { 6-8 million } \\ \text { Coho } & 12-16 \text { million } \\ \text { Fall Chinook } & 4.5-6 \text { million }\end{array}$

\section{Blind Slough (Oregon)}

Blind Slough has adequate rearing depth throughout the length of the slough. Limited 
to number of pens by the flow and velocity in the slough. Flow is dictated by runoff from Gnat Creek and minimal tidal action; variable with rainfall. Rearing access is very good via paved county roads and dikes paralleling the slough. Some piling, floats, access ramps, and docks are needed to utilize full potential. Excellent area for attracting returning adults because of the freshwater of Gnat Creek.

Pens $30-40$

Species/Numbers Spring Chinook: $600,000-800,000$, November to February rearing. Spring Chinook: 600,000-800,000, March acclimation.

Coho: $600,000-800,000$, April 1-15 acclimation.

Coho: $600,000-800,000$, April 15-30 acclimation.

Coho: $600,000-800,000$, May 1-15 acclimation.

Coho: $600,000-800,000$, May 15-30 acclimation.

Fall Chinook: 900,000-1.2 million, June-August rearing.

Spring Chinook

Coho

Fall Chinook
1.2-1.6 million

2.4-3.2 million

900,000-1.2 million

\section{Deep River / Grays Bay (Washington)}

Grays Bay appears to have the area and depth required to accommodate a modest number of rearing units. There is currently one small rearing facility in Deep River upstream of the Highway 4 bridge with 50,000 fall chinook salmon. Most ideal location is the landing in the lower stretches of Deep River at "Tiny" Tunley's, where piling and docks are available. Grays Bay would likely meet the flow and velocity requirements by a combination of flushing tidal action and freshwater inflow from Deep River, Grays . River and Seal Slough. A rearing site in Deep River would provide food protection from most extreme weather conditions. Though temperature may be a factor in the late summer/fall time periods, rearing practices could avoid the warmer times. Deep River has roadways associated with its banks that would allow installation, stocking, feeding, and maintenance of rearing net pens. Access to the water from the roads would require permission from private landowners. Deep River has the flow and chemical distinction necessary to attract adults back to the area.

Pens $40-50$ Species/Numbers

Spring Chinook: $800,000-1$ million smolts, November to February rearing.

Spring Chinook: $800,000-1$ million smolts; March acclimation.

Coho: $800,000-1$ million smolts, April 1-15 acclimation.

Coho: $800,000-1$ million smolts, April 15-30 acclimation.

Coho: $800,000-1$ million smolts, May 1-15 acclimation. 
Coho: $800,000-1$ million smolts, May $15-30$ acclimation.

Fall Chinook: 1.2-1.5 million, June-August rearing.

$\begin{array}{ll}\text { Spring Chinook } & 1.6-2 \text { million } \\ \text { Coho } & 3.2-4 \text { million } \\ \text { Fall Chinook } & 1.2-1.5 \text { million }\end{array}$

\section{Clifton Channel (Oregon)}

Clifton Channel has the area and depth to meet the minimum criteria. Piling structure at the Clifton fish station and additional potential piling sites in the vicinity are available to secure net pens. Flow and velocity characteristics at Clifton Channel are a function of both tidal and mainstem freshwater discharge. At river mile 37 the influence of the flowing tide is diminished with maximum flushing occurring during ebb tide. Protection from storm and resulting debris during winter and spring is good since the potential site is shielded from southwest storm driven wind. The potential site is however exposed to northwesterly winds which at times can produce moderate wind chop. The pen structure is sturdy enough to not have this pose a problem. Land based access to the potential site is good since a paved road from Highway 30 terminates in Clifton. The potential rearing site at Clifton is located downstream about 1.2 mile from the mouth of Hunt Creek at Bradwood. Hunt Creek's plume should follow the shoreline to provide imprinting water for the smolts.

Pens 30-40

Species/Numbers Spring Chinook: $600,000-800,000$, November to February rearing. Spring Chinook: $600,000-800,000$ smolts, March acclimation.

Coho: $600,000-800,000$ smolts, April 1-15 acclimation.

Coho: $600,000-800,000$ smolts, April 1.5-30 acclimation.

Coho: $600,000-800,000$ smolts, May $1-15$ acclimation.

Coho: 600,000-800,000 smolts, May 15-30 acclimation.

Fall Chinook: 900,000-1.2 million smolts, June-August rearing.

Spring Chinook

Coho

1.2-1.6 million

2.4-3.2 million

Fall Chinook

900,000-1.2 million

\section{Steamboat Slough (Washington)}

The Skamokawa Creek/Steamboat Slough area is constrained but appears to meet the area and depth requirements to accommodate a modest number of net pens. 'Dan Silverman's dock at his fish buying site near Skamokawa could accommodate pens, as 
might the piling with easy access at the upriver end of Steamboat Slough. This area appears to receive adequate flow, velocity, and tidal action to prevent water quality degradation. The Skamokawa Creek/Steamboat Slough area has good road access along Steamboat Slough that would allow installation, stocking, feeding and maintenance of rearing net pens. The Slough site would provide good protection from most extreme weather conditions, except access may be limited during high flows or floods. This area has sufficient flow to attract adults, but may lack distinctive chemical characteristics for precise homing.

Pens 10-20.

Species/Numbers Spring Chinook: 200,000-400,000 smolts, November to February. Spring Chinook: 200,000-400,000 smolts, March acclimation. Coho: $200,000-400,000$ smolts, April 1-15 acclimation. Coho: $200,000-400,000$ smolts, April 15-30 acclimation. Coho: 200,000-400,000 smolts, May 1-15 acclimation. Coho: $200,000-400,000$ smolts, May 15-30 acclimation. Fall Chinook: $300,000-600,000$ smolts, June-August rearing.
Spring Chinook
Coho
$400,000-800,000$
Fall Chinook
$800,000-1.6$ million
$300,000-600,000$

\section{Wallace Slough (Oregon)}

Potential rearing sites in Wallace Slough are located upstream from the mouth of the Clatskanie River along the Oregon shore. As with the Clifton site, a privately owned fish buying station provides the potential space for securing net pens. Sufficient depth and area for modest number of pens is available. With additional pilings and pens, this site has the potential for more production on the downstream bank from the confluence of the Clatskanie River. Wallace Slough at the mouth of the Clatskanie River is located at about river mile 49. Tidal effect at the potential rearing site is minor at the flood stage and flushing-action maximized during the ebb tidal stage. The long tidewater channel of the Clatskanie River dissipates the effect of the flood tide and accentuates the ebb effect, especially during high runoff periods. The potential rearing site is in a protected area from all wind and with no open water nearby wave action is minimal. Heavy runoff from the Clatskanie River should not affect the rearing site since the net pens will be located upstream of the confluence of the Clatskanie River. The Wallace fish station is accessible by paved road with equipment and related fish rearing supplies easily available. With the confluence of the Clatskanie River directly influencing the rearing area, there is a very high probability of attracting returning adults. 
Pens 20-30

Species/Numbers Spring Chinook: 400,000-600,000 smolts, November to February. Spring Chinook: 400,000-600,000 smolts, March acclimation. Coho: 400,000-600,000 smolts, April 1-15 acclimation. Coho: $400,000-600,000$ smolts, April 15-30 acclimation. Coho: 400,000-600,000 smolts, May 1-15 acclimation. Coho: 400,000-600,000 smolts, May 15-30 acclimation. Fall Chinook: $600,000-900,000$ smolts, June to August rearing.

Spring Chinook 600,000-1.2 million

Coho 1.6-2.4 million

Fall Chinook $600,000-900,000$

\section{Cathlamet Channel (Washington)}

Cathlamet Channel exceeds the minimum area and depth requirements to accommodate a maximum number of rearing pens. The Port of Cathlamet, with associated docks and pilings, is located on the Washington shoreline of the channel. This includes the upstream entry into Elochoman Slough as a potential pen rearing location. Columbia River flow would provide adequate flow and velocity to maintain water quality. John Doumit (local teacher) rears and releases salmonids in the Cathlamet sewage treatment system (Bernie Creek). The port of Cathlamet is a potential source of nitrogen, phosphate and turbidity that could impact the site. The Cathlamet Channel site would provide limited protection from most extreme weather conditions. The area could be susceptible to flood conditions that would limit access to pens. This area appears to have the chemical distinction to attract returning adults. The Doumit project has experienced returns from previous releases.

Pens 30-40 Species/Numbers

Spring Chinook: $600,000-800,000$ smolts, November to February. Spring Chinook: 600,000-800,000 smolts, March acclimation. Coho: $600,000-800,000$ smolts, April 1-15 acclimation. Coho: $600,000-800,000$ smolts, April 15-30 acclimation. Coho: $600,000-800,000$ smolts, May $1-15$ acclimation. Coho: $600,000-800,000$ smolts, May $15-30$ acclimation. Fall Chinook: 900,000-1.2 million, June to August rearing.

Spring Chinook Coho Fall Chinook
1.2-1.6 million

2.4-3.2 million 900,000-1.2 million 


\section{Youngs Bay (Expansion)}

The Youngs Bay areas presently has 80 pens in use for spring chinook, coho, and fall chinook rearing. Youngs Bay is an ideal rearing and release area; having the flow, velocity, and flushing action from the strong tidal fluctuations and several freshwater streams entering the estuary: Youngs, North Fork Klaskanine, South Fork Klaskanine, Lewis and Clark rivers, and several smaller tributaries. Access to additional rearing sites is available above and below the existing net pen site and can accommodate a substantial number of pens. Some improvements would be necessary to utilize the other sites.

Pens 60-70 Species/Numbers Spring Chinook: 1.4-1.7 million, November to February rearing. Spring Chinook: 1.4-1.7 million, March acclimation. Coho: 1.4-1.7 million smolts, April 1-15 acclimation. Coho: 1.4-1.7 million smolts, April 15-30 acclimation. Coho: 1.4-1.7 million smolts, May 1-15 acclimation. Coho: 1.4-1.7 million smolts, May 15-30 acclimation. Fall Chinook: 2.1-2.5 million, June to August rearing.

Spring Chinook Coho Fall Chinook
2.8-3.4 million

5.6-6.8 million

2.1-2.5 million 


\section{B: Estimated Cost by Site}

\section{INTRODUCTION}

Estimates of production capabilities and associated costs will be made using the experience gained by the CEDC Fisheries Project in Youngs Bay, Oregon. The evolution of developing the net pen rearing program in Youngs Bay has been rapid and extremely successful. With the initial experiments in 1988 using eight pens, to the present 75 pens in 1995, valuable experience has been gained in determining the budgetary needs to efficiently produce quality salmon smolts for release. Subsequent survival rates of adult salmon from net pen releases have out performed those from traditional hatcheries and allowed for the commitment of the entire return to Youngs Bay for terminal harvest.

The cost estimates generated in this chapter will be used in development of a Business Plan for lower Columbia River terminal salmon fisheries. The Business Plan will be produced by SFA, an industry based association, using the contract services of Dr. Hans D. Radtke, resource economist. The cost estimates developed for each potential terminal fishery site were produced by Jim Hill, project director of the CEDC Fishery Project.

\section{METHODS}

To develop cost estimates for each potential terminal fishery site, pen capacity of each site first had to be estimated, then associated capital costs (i.e. piling, barges, feed storage, etc.), annual operating and maintenance costs associated with the facility (leases, permits, material, and salaries), and annual costs associated with the fish culture activities (feed, trucking, fin clipping, CWT operations).

To illustrate a full scale rearing and release program for terminal fisheries a maximum range of pens for each site was determined. Then salmon stocks and rearing regimes were chosen to simulate a full production program with a goal of maximizing rearing operations while utilizing all available stocks of salmon (spring chinook, fall chinook and coho).

\section{RESULTS AND DISCUSSION}

Production capacity in terms of net pen structure is determined to be a range between 370 and 490 new pens for the seven selected sites, including the Youngs Bay expansion șite (Table 29). Assuming for each site the same stocks and rearing schedules are used, between $\mathbf{5 7 . 0}$ million and 75.7 million smolts could potentially be reared, acclimated, and released. The Tongue Point site in our opinion possesses the most potential capacity with space for up to 200 pens resulting in a potential of 30 million smolts released. 
Table 29. Projected smolt releases after acclimation and rearing, by site.

\begin{tabular}{|c|c|c|c|c|c|c|c|c|c|c|}
\hline Acclimation /Release Site & $\begin{array}{l}\text { Tongue } \\
\text { Point } \\
\end{array}$ & $\begin{array}{r}\text { Blind } \\
\text { Slough } \\
\end{array}$ & $\begin{array}{l}\text { Deep } \\
\text { River }\end{array}$ & $\begin{array}{r}\text { Clifton } \\
\text { Channel } \\
\end{array}$ & $\begin{array}{r}\text { Steamboat } \\
\text { Slough }\end{array}$ & $\begin{array}{r}\text { Wallace } \\
\text { Slough } \\
\end{array}$ & $\begin{array}{l}\text { CathlametY } \\
\text { Channel }\end{array}$ & $\begin{array}{l}\text { oungs BayY } \\
\text { (existing) (e }\end{array}$ & $\begin{array}{l}\text { (oungs Bay } \\
\text { expansion) }\end{array}$ & $\begin{array}{l}\text { Total New } \\
\text { Production } \\
\end{array}$ \\
\hline $\begin{array}{l}\text { Number of Net Pens (Alt 1) } \\
\text { Number of Net Pens (Alt. 2) }\end{array}$ & $\begin{array}{l}150 \\
200\end{array}$ & $\begin{array}{l}30 \\
40\end{array}$ & $\begin{array}{l}40^{\circ} \\
50\end{array}$ & $\begin{array}{l}30 \\
40\end{array}$ & $\begin{array}{l}10 \\
20\end{array}$ & $\begin{array}{l}20 \\
30\end{array}$ & $\begin{array}{l}30 \\
40\end{array}$ & $\begin{array}{l}80 \\
80\end{array}$ & $\begin{array}{l}60 \\
70\end{array}$ & $\begin{array}{l}370 \\
490\end{array}$ \\
\hline $\begin{array}{l}\text { Species/Numbers (Alt. 1) millions } \\
\text { Spring Chinook Nov-Feb rearing } \\
\text { Spring Chinook Mar. acclimation } \\
\text { Coho, April 1-15 } \\
\text { Coho, April 15-30 } \\
\text { Coho, May 1-15 } \\
\text { Coho, May 16-31 } \\
\text { Fall Chinook (URB, RRB) June-Aug. } \\
\text { Total }\end{array}$ & $\begin{array}{l}3.0 \\
3.0 \\
3.0 \\
3.0 \\
3.0 \\
3.0 \\
4.5 \\
22.5\end{array}$ & $\begin{array}{l}0.6 \\
0.6 \\
0.6 \\
0.6 \\
0.6 \\
0.6 \\
0.9 \\
4.5\end{array}$ & $\begin{array}{l}0.8 \\
0.8 \\
0.8 \\
0.8 \\
0.8 \\
0.8 \\
1.2 \\
5.0\end{array}$ & $\begin{array}{l}0.6 \\
0.6 \\
0.6 \\
0.6 \\
0.6 \\
0.6 \\
0.9 \\
4.5\end{array}$ & $\begin{array}{l}0.2 \\
0.2 \\
0.2 \\
0.2 \\
0.2 \\
0.2 \\
0.3 \\
1.5\end{array}$ & $\begin{array}{l}0.4 \\
0.4 \\
0.4 \\
0.4 \\
0.4 \\
0.4 \\
0.6 \\
3.0\end{array}$ & $\begin{array}{l}0.6 \\
0.6 \\
0.6 \\
0.6 \\
0.6 \\
0.6 \\
\underline{0.9}\end{array}$ & $\begin{array}{r}1.9 \\
1.9 \\
1.9 \\
1.9 \\
1.9 \\
1.9 \\
2.8 \\
14.0\end{array}$ & $\begin{array}{r}1.4 \\
1.4 \\
1.4 \\
1.4 \\
1.4 \\
1.4 \\
\underline{2.1} \\
10.5\end{array}$ & $\begin{array}{r}7.6 \\
7.6 \\
7.6 \\
7.6 \\
7.6 \\
7.6 \\
11.4 \\
57.0\end{array}$ \\
\hline $\begin{array}{l}\text { Species/Numbers (Alt. 2) millions } \\
\text { Spring Chinook Nov-Feb rearing } \\
\text { Spring Chinook Mar. acclimation } \\
\text { Coho, April 1-15 } \\
\text { Coho, April 15-30 } \\
\text { Coho, May 1-15 } \\
\text { Fall Chinook (URB, RRB) June-Aug. } \\
\text { Total }\end{array}$ & $\begin{array}{r}4.0 \\
4.0 \\
4.0 \\
4.0 \\
4.0 \\
6.0 \\
30.0\end{array}$ & $\begin{array}{l}0.8 \\
0.8 \\
0.8 \\
0.8 \\
0.8 \\
1.2 \\
6.0\end{array}$ & $\begin{array}{l}1.0 \\
1.0 \\
1.0 \\
1.0 \\
1.0 \\
1.5 \\
7.5\end{array}$ & $\begin{array}{l}0.8 \\
0.8 \\
0.8 \\
0.8 \\
0.8 \\
1.2 \\
6.0\end{array}$ & $\begin{array}{l}0.4 \\
0.4 \\
0.4 \\
0.4 \\
0.4 \\
0.6 \\
3.0\end{array}$ & $\begin{array}{l}0.6 \\
0.6 \\
0.6 \\
0.6 \\
0.6 \\
0.9 \\
4.5\end{array}$ & $\begin{array}{l}0.8 \\
0.8 \\
0.8 \\
0.8 \\
0.8 \\
1.2 \\
6.0\end{array}$ & $\begin{array}{r}1.9 \\
1.9 \\
1.9 \\
1.9 \\
1.9 \\
2.8 \\
14.0\end{array}$ & $\begin{array}{r}1.7 \\
1.7 \\
1.7 \\
1.7 \\
1.7 \\
2.5 \\
12.7\end{array}$ & $\begin{array}{l}10.1 \\
10.1 \\
10.1 \\
10.1 \\
10.1 \\
15.1 \\
75.7\end{array}$ \\
\hline
\end{tabular}


Capitalization cost associated with full scale implementation of the terminal fishery program at the lowest of range of maximum production ( 370 pens) is displayed in Table 30. The largest portion of the initial outlay of capital is for purchase of net pen structures and nets (Appendix 5). A total capital expenditure of $\$ 3,536,000$ is estimated.

Associated operation and maintenance (O\&M) costs are displayed in Table 31 and detailed in Appendix 6 . An estimated $\$ 2,968,000$ would be needed annually in the initial year of the full scale program with about $\$ 3,025,600$ annually for the second year and beyond to account for replacement netting $(\$ 58,800)$.

Total cost of a full scale production program with 370 pens producing 57.0 million smolts at eight terminal fishery sites would be $\$ 6,504,000$ if initiated in a single year. Annual costs in the subsequent years would be about $\$ 3,025,600$ for O\&M.

Implementation of a full scale program will not be an overnight process. The purpose of this exercise was to provide the basis for a business plan which will present detailed economic analysis of the program. Also, this exercise displays the magnitude and monetary commitment necessary to fully implement a full scale terminal fishery program.

A step-wise, progressive growth in the terminal fishery program is certainly the most prudent and productive path to full implementation. Which sites to expand and which stocks to use will depend on initial research results, stock availability, and stock desirability. It is premature to present estimates of costs for partial implementation at this time. Conceptually priority for capitalization is initiation of research at the lower most sites of Tongue Point, Blind Slough, Deep River, and Youngs Bay (expansion). 
Table 30. Capitalization cost estimates for proposed terminal fishery sites.

\begin{tabular}{lrrr}
\hline Site & Pens & $\ddots$ & $\begin{array}{r}\text { Total } \\
\text { Capital }\end{array}$ \\
\hline Tongue Point & 150 & $\ddots$ & $\$ 914,100$ \\
Blind Slough & 30 & & 198,000 \\
Deep River & 40 & & 291,400 \\
Clifton Channel & 30 & 194,650 \\
Steamboat Slough & 10 & 76,650 \\
Wallace Slough & 20 & 139,900 \\
Cathlamet Channel & 30 & 203,150 \\
Youngs Bay & 60 & & 423,300 \\
$\quad$ Subtotal & 370 & & $\$ 2,441,150$ \\
Non-site Specific & & $\$ 95,000$ \\
$\quad$ Tanker Trucks & & $\$ 1,000,000$ \\
Total Capital & & & $\$ 3,536,150$ \\
\hline
\end{tabular}

Table 31. Operation and maintenance cost estimates for proposed terminal fishery sites.

\begin{tabular}{lrrr}
\hline Site & Pens & $\begin{array}{r}\text { Millions } \\
\text { of Smolts }\end{array}$ & Total O\&M Costs \\
\hline Tongue Point & 150 & 22.5 & $\$ 924,500$ \\
Blind Slough & 30 & 4.5 & 204,180 \\
Deep River & 40 & 6.0 & 264,618 \\
Clifton Channel & 30 & 4.5 & 204,180 \\
Steamboat Slough & 10 & 1.5 & 84,578 \\
Wallace Slough & 20 & 3.0 & 145,056 \\
Cathlamet Channel & 30 & 4.5 & 204,180 \\
Youngs Bay & 60 & 10.5 & 444,428 \\
$\quad$ Subtotal & 370 & 57.0 & $\$ 2,475,720$ \\
Project Personnel & & & $\$ 592,244$ \\
Total O\&M & & & $\$ 2,967,964$ \\
Replacement Nets & & & $\$ 58,800$ \\
Total O\&M Annually & & & $\$ 3,025,564$ \\
\hline
\end{tabular}

Includes $100 \%$ fin clipping for releases of coho and fall chinook. 


\section{Columbia River Terminal Fishery Development Scenario}

*Note: This is just one suggested scenario. Actual development depends on many factors and may happen more gradual, or faster than suggested.

Phase $1 \quad-B y$ year 1998

-Maximize Youngs Bay production

Total Pens

-Begin development at Tongue Point beyond research

Youngs Bay $/ 60$ additional pens

Tongue Point / 50 additional pens

Phase 2. -By year 2002

-Optimize research ability at other sites

-Expand harvest area/production

Blind Slough / 20 additional pens

Deep River / 20 additional pens

Clifton / 10 pens

Cathlamet / 10 pens

Phase 3 -By year 2005

-Develop each site to full potential

Youngs Bay / $0-10$ additional pens

Tongue Point / 40-140 additional pens

Blind Slough / 0-10 additional pens

Deep River / 10-20 additional pens

$40-50$

Clifton / 20-30 additional pens

$30-40$

Cathlamet / 20-30 additional pens

$30-40$

Phase 4 -By year 2010

-Research and develop higher-cost sites

Steamboat Slough / 10-20 additional pens

$10-20$

Wallace Slough / 20-30 additional pens 


\section{CHAPTER 7: DESCRIPTION OF OPERATIONAL REPERCUSSIONS OF TERMINAL FISHERIES PROGRAMS ON EXISTING HATCHERY PROGRAMS}

\section{INTRODUCTION}

A role of salmon and steelhead hatcheries in the Columbia River Basin has been to replace lost anadromous salmonid production caused by hydroelectric projects, irrigation diversions, flood control dams, and other human activities. Funding for Columbia River hatchery programs is diverse with major portions from the federal government under the Columbia River Fisheries Development Program created by the Mitchell Act. Private power entities and Army Corps of Engineers fund hatcheries to mitigate for lost production directly resulting from their activities. The responsibility of the hatchery programs is not only to perpetuate the species for health and genetic diversity, but to provide fish for harvest and other less tangible enjoyment that are in excess of fish cultural needs.

\section{DISCUSSION}

Columbia River sailmon are harvested in ocean fisheries from Alaska to California and in freshwater fisheries in the mainstem and tributaries of the Columbia. Because of declines in most wild salmon stocks in the Columbia basin and for all stocks in the Snake River basin traditional harvest allocation for hatchery salmon stocks have been severely reduced or eliminated especially in mainstem.Columbia River fisheries. Listing of Snake River wild chinook and sockeye as threatened or endangered under the ESA in recent years has drastically curtailed harvest in traditional mainstem fisheries.

An example of harvest rate reduction resulting from the ESA threatened listing for Snake River wild (SRW) spring/summer chinook is displayed in Table 32. The average harvest rates for Willamette River spring chinook in the Columbia River prior to 1992 when SRW spring/summer chinook were listed ranged between $9.4-17.7 \%$. During 1992-94 the average harvest rate fell to $6.4 \%$. The commercial fishery harvest rates -have declined most dramatically with an average of $6.8-14.1 \%$ during $1970-91$ dropping to $3.3 \%$ during $1992-94$.

To provide access to harvestable hatchery fish while protecting stocks listed under ESA will require commitment of hatchery production to terminal off-channel areas. Large scale net pen rearing programs could utilize that portion of hatchery production allocated to mainstem Columbia River fisheries for harvest opportunities.

The effect of allocating a portion of a hatchery's production to a satellite net pen 
acclimation program can only be generalized at this time. If the aggregate annual smolt production ceiling of 197.4 million smolts is the rule for the Columbia River basin, additional juveniles will not be available for terminal fisheries net pen programs:

1) On-station hatchery operation and maintenance costs will decrease with. fewer smolts released from the hatchery.

2) Trucking costs will increase as more hatchery production is programmed for terminal areás.

3) With proper planning, adequate numbers for adults for brood stock purposes will return to hatcheries.

At full potential, a total of 57 million smolts could be released from expanded terminal fishery sites with 370 new net pen units (Table 33). Assuming no restrictions or limitations exist for reaching full potential, a total of 15.2 million spring chinook, 11.4 million fall chinook, and 30.4 million coho could potentially be released from five Oregon and three Washington terminal fishery sites in addition to the existing production in Youngs Bay. Realistically, limitations and restrictions will change the species mix and perhaps the total number of smolts released for full utilization of terminal fishery sites. Traditional hatchery operations and procedures will change dramatically to accommodate the shift in smolt production to terminal sites. Specific changes in operations at hatcheries cannot be addressed until program changes are decided. 
Table 32. Average harvest rates for Willamette spring chinook in Columbia River mainstem fisheries, 1970-94.

\begin{tabular}{|c|c|c|c|c|c|c|c|}
\hline \multirow{4}{*}{ Year } & \multicolumn{6}{|c|}{ Lower Columbia River Fisheries } & \multirow{4}{*}{$\begin{array}{l}\text { Willamette } \\
\text { Minimum } \\
\text { Run Size }\end{array}$} \\
\hline & \multicolumn{2}{|c|}{ Commercial } & \multicolumn{2}{|c|}{ Sport } & \multicolumn{2}{|r|}{ Total } & \\
\hline & & Harvest & & tarvest & & Harvest & \\
\hline & Catch & Rate & Catch & Rate & Catch & Rate & \\
\hline $1970-74$ & 10,100 & $14.1 \%$ & 2,600 & $3.6 \%$ & 12,700 & $17.7 \%$ & 71,600 \\
\hline $1975-79$ & 5,400 & $9.5 \%$ & 1,600 & $2.8 \%$ & 7,000 & $12.4 \%$ & 56,600 \\
\hline $1980-84$ & 4,400 & $6.8 \%$ & 1,700 & $2.6 \%$ & 6,100 & $9.4 \%$ & 64,800 \\
\hline $1985-89$ & 9,800 & $10.5 \%$ & 2,200 & $2.2 \%$ & $.12,000$ & $12.8 \%$ & 93,700 \\
\hline 1990-91 & 13,400 & $11.1 \%$ & 6,200 & $5.2 \%$ & 19,600 & $16.3 \%$ & 120,300 \\
\hline $1992-94$ & 1,900 & $3.3 \%$ & 1,800 & $3.1 \%$ & 3,700 & $6.4 \%$ & 57,800 \\
\hline
\end{tabular}

Table 33. Release site operation plans.

\begin{tabular}{|c|c|c|c|c|c|c|c|c|c|}
\hline & $\begin{array}{r}\text { Tongue } \\
\text { Point } \\
\end{array}$ & $\begin{array}{l}\text { Blind } \\
\text { Slough }\end{array}$ & $\begin{array}{r}\text { Deep RI } \\
\text { Grays Bay }\end{array}$ & Clifton & $\begin{array}{r}\text { Steamboat } \\
\text { Slough }\end{array}$ & $\begin{array}{l}\text { Wallace } \\
\text { Slough }\end{array}$ & $\begin{array}{r}\text { Cathlamet } \\
\text { Channel } \\
\end{array}$ & $\begin{array}{l}\text { Youngs Bay } \\
\text { (expansion) }\end{array}$ & $\begin{array}{l}\text { Total New } \\
\text { Production }\end{array}$ \\
\hline Pens & 150 & 30 & 40 & 30 & 10 & 20 & 30 & 60 & 370 \\
\hline \multicolumn{10}{|l|}{ Stock (millions) } \\
\hline Spring Chinook (Nov.-Feb.) & 3.0 & 0.6 & 0.8 & 0.6 & 0.2 & 0.4 & 0.6 & 1.4 & 7.6 \\
\hline Spring Chinook (March) & 3.0 & 0.6 & 0.8 & 0.6 & 0.2 & 0.4 & 0.6 & 1.4 & 7.6 \\
\hline Coho (April 1-15) & 3.0 & 0.6 & 0.8 & 0.6 & 0.2 & 0.4 & 0.6 & 1.4 & 7.6 \\
\hline Coho (April 15-30) & 3.0 & 0.6 & 0.8 & 0.6 & 0.2 & 0.4 & 0.6 & 1.4 & 7.6 \\
\hline Coho (May 1-15) & 3.0 & 0.6 & 0.8 & 0.6 & 0.2 & 0.4 & 0.6 & 1.4 & 7.6 \\
\hline Coho (May 16-31) & 3.0 & 0.6 & -0.8 & 0.6 & 0.2 & 0.4 & 0.6 & 1.4 & 7.6 \\
\hline Fall Chinook (June-Aug.) & $\underline{3.0}$ & $\underline{0.6}$ & $\underline{0.8}$ & $\underline{0.6}$ & $\underline{0.2}$ & $\underline{0.4}$ & $\underline{0.6}$ & 1.4 & 7.6 \\
\hline Total & 22.5 & 4.5 & 6.0 & 4.5 & 1.5 & 3.0 & 4.5 & 10.5 & 57.0 \\
\hline
\end{tabular}




\section{CHAPTER 8. POTENTIAL IMPACTS ON UPRIVER BRIGHT AND SNAKE RIVER WILD FALL CHINOOK ESCAPEMENT THROUGH VARIOUS REDUCTIONS OF THE NON-INDIAN COMMERCIAL FISHERY}

\section{INTRODUCTION.}

Once they have survived to adults entering the mouth of the Columbia River, the number of Upriver Bright (URB) and Snake River wild (SRW) stock fall chinook that reach escapement areas are dependent on two main factors: fishery harvest rates and Columbia River hydroelectric system passage losses. This chapter will focus on the impacts of reducing the non-Indian commercial fishery harvest rates on those stocks under two different passage loss scenarios.

There are two distinct commercial fisheries separated geographically at Bónneville Dam. The non-Indian fishery is an all-citizens fishery below Bonneville Dam. The treaty Indian fishery occurs in the main stem Columbia between Bonneville and McNary dams. Four Columbia River tribes are involved in the commercial fishery in this area called Zone 6.

All fisheries of the Columbia River are established within the guidelines and constraints of the Columbia River Fish Management Plan (CRFMP) and the Endangered Species Act (ESA). The CRFMP adopted by Court in October of 1988 provides a framework within which the Parties may exercise their sovereign powers in a coordinated and systematic manner in order to protect, rebuild, and enhance upper Columbia River fish runs while providing harvests for both treaty Indian and non-Indian fisheries in the ocean and Columbia River Basin. Treaty Indian and non-Indian fisheries are required to be shared equally ( $50 \%$ each) the upriver fall chinook available for harvest in the Pacific Ocean south of the southwesterly projection of the United States -Canada boundary between British Columbia and Washington and in the main-stem Columbia River below Priest Rapids Dam.

In May 1992, the Snake River wild portion of the Columbia River fall chinook run was listed as threatened. The National Marine Fisheries Service (NMFS) considers biological assessment reports for in-basin fisheries; issues biological opinions and incidental take statements.

The Columbia River fall chinook fisheries have been primarily managed under the CRFMP in an attempt to achieve escapement objectives relative to natural and hatchery requirements as well as 40,000 adult fish passing McNary Dam. During 199094, the parties to U.S. v. Oregon agreed to increase the McNary Dam goal to 45,000 adults to accommodate increased hatchery escapement needs. It is also recognized that the increased McNary Dam goal provides additional benefits for Snake River fall 
chinook escapement.

The Columbia River average harvest rate of SRW fall chinook was $48.6 \%$ during 1986 90. The harvest rate of URB fall chinook was limited by the level of SRW harvest and not by the McNary Dam escapement. The harvest rate of URBs during this period was $59.1 \%$. The following is a model that incorporates reducing the current non-Indian commercial harvest rates and reallocates portions of the saved fish to the treaty Indian fisheries using two different passage conversion rates.

\section{METHODS}

The potential impacts of reducing the non-Indian commercial fishery harvest rate was based on a theoretical URB adult run size of 200,000 and 1,000 SRW adult fall chinook entering the mouth of the Columbia River. Six thousand of the URBs were expected to enter the Deschutes River in Oregon. The run sizes used are somewhat reasonable and comparable to recent year averages.

To divide the harvest between treaty Indian and non-Indian fishers, it was assumed the treaty Indians would receive their full $50 \%$ share of the harvestable surplus. NonIndian fishers would harvest the remainder of the assumed total harvest rate including a lower river and Hanford Reach sport catch of 2,000 and 3,000 adults, respectively.

The most accurate picture of improving URB and SRW escapement would not be complete without the other major contributing factor, passage loss. Passage losses are fish counted at a particular dam but are unaccounted for at the next dam upstream after accounting for all fishery catches and tributary turnoff between the dams. During 198690 , the average passage conversion rates between Bonneville and Lower Granite Dams were poor at $33.4 \%$ (passage loss at $66.6 \%$ ). The 1990-94 average conversion rates improved to $46.6 \%$ (passage loss of $53.4 \%$ ). The model displays the true effects of reduced non-Indian commercial fishery harvest rates based on the two different rates. of dam passage losses.

The column in the models titled "Percent Increase Over Base" is simply the percent increase in the number of fish that reached the spawning ground over that harvest level and passage conversion rate. This column gives the best general view of the effects of any changes to non-Indian commercial harvest rates depending on the treaty Indian fishery harvest and passage conversion rates.

\section{RESULTS}

The largest increase over base (41.0\%) for SRW fall chinook occurs when the lower 
river (non-Indian) commercial harvest rates are reduced 100\% (no fish are caught), none of the saved fish are reallocated to the treaty Indian harvest, and the passage conversion rates are the highest. A total of. 337 SRW fall chinook would reach spawning areas above Lower Granite Dam in this best case scenario, an increase of 98 fish over the base using the same passage rates.

The smallest increase over base (4.6\%) for SRW fall chinook occurs when the nonIndian commercial harvest rates are reduced $50 \%$ and $80 \%$ of the fish saved are reallocated to the treaty Indian harvest and the dam passage conversion rates are the lowest. A total of 181 SRW fall chinook would reach the spawning grounds, an increase of eight fish over the base using the same passage rates. Table 34 displays the potential impacts on SRW fall chinook of various harvest reductions in the nonIndian commercial fishery with various reallocations to treaty Indian harvest using two different passage conversion rates.

The scenarios that would result in the largest and smallest SRW fall chinook percent increase over base also affect URBs in the same manner. If the non-Indian commercial fisheries were reduced $100 \%$ (no fish caught), none of the saved fish were reallocated to the treaty Indian harvest and passage rates were the highest, the URB increase over base would be $64.2 \%$. A total of 42,155 more URBs would escape over McNary Dam. If the non-Indian commercial harvest rates were reduced $50 \%$ and $80 \%$ of the fish saved are reallocated to the treaty Indian harvest and passage conversion was the lowest, the URB increase in base would be $6.8 \%$. Slightly less than 4,000 more URBs would escape over McNary Dam. Table 35 displays the potential impacts on URB fall chinook of various harvest reduction levels in the non-Indian commercial fishery with various reallocations to the treaty Indian harvest using the two different conversion rates.

\section{DISCUSSIONS}

Improving passage conversion rates greatly increases the escapement. Based on current SRW harvest rates, improved passage conversion rates alone result in 66 more SRW fall chinook reaching spawning areas above Lower Granite Dam.

Improving passage also greatly enhances the effects of any harvest reduction. For example, the highest passage conversion rate during the base period was $63.4 \%$ in 1993. If the lower river-non-Indian commercial fishery was reduced by just $15 \%$ and none of the fish saved allocated to the treaty Indian fisheries, the resulting increase in the Lower Granite Dam escapement would be 99 adults, an increase over the best escapement that eliminated the entire lower river commercial fishery.

Eliminating the non-Indian commercial fishery and reducing the treaty Indian 
commercial harvest would increase the escapement of both URBs and SRWs but may have a negative impact on URBs. The URB escapement would increase to twice the goal for McNary Dam.

The changes in non-Indian and treaty Indian commercial harvest rates are merely for display. Actual harvests are based on the provisions of the CRFMP, annual management agreements, and ESA requirements.

The potential impacts could be used to measure the importance of switching various levels of lower Columbia River main-stem commercial fisheries to terminal areas. The intent of terminal fisheries is to provide sustainable harvest opportunities while rebuilding weak upriver salmon stocks. While terminal fisheries are not intended to replace lower Columbia River main-stem commercial fisheries, terminal fisheries are designed to harvest healthy stocks while reducing potential interceptions of weaker ones. 
Table 34. Projected impacts on Snake River wild fall chinook from various harvest reductions in the lower Columbia River commercial fishery with various pass-through rates and two different passage conversions.

\begin{tabular}{|c|c|c|c|c|c|c|c|c|}
\hline $\begin{array}{c}\text { L.R. } \\
\text { Commercial } \\
\text { Base HR } \\
\text { Reduction } \\
\end{array}$ & $\begin{array}{l}\text { Reduction } \\
\text { Allocated } \\
\text { to Zone } 6 \\
\end{array}$ & $\begin{array}{l}\text { Col.River } \\
\text { Harv.Rate }\end{array}$ & $\begin{array}{c}\text { L.R. } \\
\text { Commercial } \\
\text { Harvest }\end{array}$ & $\begin{array}{c}\text { Zone } 6 \\
\text { Commercial } \\
\text { Harvest }\end{array}$ & $\begin{array}{c}\text { Dam Passage b/ } \\
\text { Conversion }\end{array}$ & $\begin{array}{c}\text { Passage } \\
\text { Loss }\end{array}$ & $\begin{array}{r}\text { LGD } \\
\text { Escape } \\
\end{array}$ & $\begin{array}{r}\text { Percent } \\
\text { Increase } \\
\text { Over } \\
\text { Base } \\
\end{array}$ \\
\hline $\begin{array}{r}0.0 \% \\
50.0 \% \\
75.0 \% \\
100.0 \%\end{array}$ & $\begin{array}{l}0.0 \% \\
0.0 \% \\
0.0 \% \\
0.0 \%\end{array}$ & $\begin{array}{l}48.6 \% \\
38.0 \% \\
32.6 \% \\
27.3 \%\end{array}$ & $\begin{array}{r}213 \\
106 \\
53 \\
0\end{array}$ & $\begin{array}{l}264 \\
264 \\
264 \\
264\end{array}$ & $\begin{array}{l}\text { 1990-94 Ave. } \\
\text { 1990-94 Ave. } \\
\text { 1990-94 Ave. } \\
1990-94 \text { Ave. }\end{array}$ & $\begin{array}{l}275 \\
333 \\
361 \\
390\end{array}$ & $\begin{array}{r}239 \\
288 \\
313 \\
-\quad 337\end{array}$ & $\begin{array}{r}0.0 \% \\
20.5 \% \\
31.0 \% \\
41.0 \%\end{array}$ \\
\hline $\begin{array}{l}50.0 \% \\
50.0 \% \\
50.0 \%\end{array}$ & $\begin{array}{l}20.0 \% \\
50.0 \% \\
80.0 \%\end{array}$ & $\begin{array}{l}39.8 \% \\
42.7 \% \\
45.5 \%\end{array}$ & $\begin{array}{l}106 \\
106 \\
106\end{array}$ & $\begin{array}{l}283 \\
311 \\
339\end{array}$ & $\begin{array}{l}\text { 1990-94 Ave. } \\
\text { 1990-94 Ave. } \\
\text { 1990-94 Ave. }\end{array}$ & $\begin{array}{l}322 \\
307 \\
292\end{array}$ & $\begin{array}{l}279 \\
266 \\
253\end{array}$ & $\begin{array}{r}16.7 \% \\
11.3 \% \\
5.9 \%\end{array}$ \\
\hline $\begin{array}{l}75.0 \% \\
75.0 \% \\
75.0 \%\end{array}$ & $\begin{array}{l}20.0 \% \\
50.0 \% \\
80.0 \%\end{array}$ & $\begin{array}{l}35.5 \% \\
39.7 \% \\
43.9 \%\end{array}$ & $\begin{array}{l}53 \\
53 \\
53\end{array}$ & $\begin{array}{l}292 \\
335 \\
377\end{array}$ & $\begin{array}{l}\text { 1990-94 Ave. } \\
\text { 1990-94 Ave. } \\
\text { 1990-94 Ave. }\end{array}$ & $\begin{array}{l}346 \\
323 \\
300\end{array}$ & $\begin{array}{l}299 \\
280 \\
260\end{array}$ & $\begin{array}{r}25.1 \% \\
17.2 \% \\
8.8 \%\end{array}$ \\
\hline $\begin{array}{l}100.0 \% \\
100.0 \% \\
100.0 \%\end{array}$ & $\begin{array}{l}20.0 \% \\
50.0 \% \\
80.0 \%\end{array}$ & $\begin{array}{l}31.1 \% \\
36.7 \% \\
42.4 \%\end{array}$ & $\begin{array}{l}0 \\
0 \\
0\end{array}$ & $\begin{array}{l}302 \\
358 \\
415\end{array}$ & $\begin{array}{l}\text { 1990-94 Ave. } \\
\text { 1990-94 Ave. } \\
\text { 1990-94 Ave. }\end{array}$ & $\begin{array}{l}369 \\
339 \\
309\end{array}$ & $\begin{array}{l}320 \\
294 \\
267\end{array}$ & $\begin{array}{l}33.9 \% \\
23.0 \% \\
11.7 \%\end{array}$ \\
\hline $\begin{array}{r}0.0 \% \\
50.0 \% \\
75.0 \% \\
100.0 \%\end{array}$ & $\begin{array}{l}0.0 \% \\
0.0 \% \\
0.0 \% \\
0.0 \%\end{array}$ & $\begin{array}{l}48.6 \% \\
39.3 \% \\
34.7 \% \\
30.0 \%\end{array}$ & $\begin{array}{r}186 \\
93 \\
46 \\
0\end{array}$ & $\begin{array}{l}291 \\
291 . \\
291 \\
291\end{array}$ & $\begin{array}{l}\text { 1986-90 Ave. } \\
\text { 1986-90 Ave. } \\
\text { 1986-90 Ave. } \\
1986-90 \text { Ave. }\end{array}$ & $\begin{array}{l}341 \\
402 \\
433 \\
464\end{array}$ & $\begin{array}{l}173 \\
204 \\
220 \\
236\end{array}$ & $\begin{array}{r}0.0 \% \\
17.9 \% \\
27.2 \% \\
36.4 \%\end{array}$ \\
\hline $\begin{array}{l}50.0 \% \\
50.0 \% \\
50.0 \%\end{array}$ & $\begin{array}{l}20.0 \% \\
50.0 \% \\
80.0 \%\end{array}$ & $\begin{array}{l}41.1 \% \\
43.7 \% \\
46.3 \%\end{array}$ & $\begin{array}{l}93 \\
93 \\
93\end{array}$ & $\begin{array}{l}309 \\
335 \\
361\end{array}$ & $\begin{array}{l}\text { 1986-90 Ave. } \\
\text { 1986-90 Ave. } \\
\text { 1986-90 Ave. }\end{array}$ & $\begin{array}{l}391 \\
373 \\
356\end{array}$ & $\begin{array}{l}199 \\
190 \\
181\end{array}$ & $\begin{array}{r}15.0 \% \\
9.8 \% \\
4.6 \%\end{array}$ \\
\hline $\begin{array}{l}75.0 \% \\
75.0 \% \\
75.0 \%\end{array}$ & $\begin{array}{l}20.0 \% \\
50.0 \% \\
80.0 \%\end{array}$ & $\begin{array}{l}37.3 \% \\
41.3 \% \\
45.2 \%\end{array}$ & $\begin{array}{l}46 \\
46 \\
46\end{array}$ & $\begin{array}{l}318 \\
357 \\
397\end{array}$ & $\begin{array}{l}1986-90 \text { Ave. } \\
\text { 1986-90 Ave. } \\
1986-90 \text { Ave. }\end{array}$ & $\begin{array}{l}416 \\
390 \\
363\end{array}$ & $\begin{array}{l}211 \\
198 \\
185\end{array}$ & $\begin{array}{r}22.0 \% \\
14.5 \% \\
6.9 \%\end{array}$ \\
\hline $\begin{array}{l}100.0 \% \\
100.0 \% \\
100.0 \%\end{array}$ & $\begin{array}{l}20.0 \% \\
50.0 \% \\
80.0 \%\end{array}$ & $\begin{array}{l}33.5 \% \\
38.8 \% \\
44.1 \%\end{array}$ & $\begin{array}{l}0 \\
0 \\
0\end{array}$ & $\begin{array}{l}326 \\
379 \\
432\end{array}$ & $\begin{array}{l}\text { 1986-90 Ave. } \\
\text { 1986-90 Ave. } \\
\text { 1986-90 Ave. }\end{array}$ & $\begin{array}{l}441 \\
405 \\
371\end{array}$ & $\begin{array}{l}224 \\
206 \\
188\end{array}$ & $\begin{array}{r}29.5 \% \\
19.1 \% \\
8.7 \%\end{array}$ \\
\hline
\end{tabular}

al Assumptions: 200,000 URB, 1,000 SRW run size, 6,000 Deschutes turn off, 2,000 lower river sport, 3,000 Hanford sport, and Treaty Indian at $50 \%$; non-Indian at $40 \%$ of URB harvestable surplus at base harvest rate of $48.6 \%$ on SRW (1986-90 average harvest rate).

b/ $1990-94$ average conversion: Bonneville-LGD $=.4664$. $1986-90$ average conversion: Bonneville-LGD $=.3345$. 
Table 35. Projected impacts on Upriver Bright fall chinook at various harvest reductions in the lower Columbia River commercial fishery with various-pass through rates and two different dam passage conversions.

\begin{tabular}{|c|c|c|c|c|c|c|c|c|}
\hline $\begin{array}{c}\text { L.R. } \\
\text { Commercial } \\
\text { Base HR } \\
\text { Reduction } \\
\end{array}$ & $\begin{array}{l}\text { Reduction } \\
\text { Allocated } \\
\text { to Zone } 6 \\
\end{array}$ & $\begin{array}{l}\text { Col.River } \\
\text { Harv.Rate } \\
\end{array}$ & $\begin{array}{c}\text { L.R. } \\
\text { Commercial } \\
\text { Harvest }\end{array}$ & $\begin{array}{c}\text { L.R. } \\
\text { Commercial } \\
\text { Harvest }\end{array}$ & $\begin{array}{c}\text { Dam Passage b/ } \\
\text { Conversion }\end{array}$ & $\begin{array}{r}\text { Passage } \\
\text { Loss } \\
\end{array}$ & $\begin{array}{l}\text { McNary } \\
\text { Escape }\end{array}$ & $\begin{array}{r}\text { Percent } \\
\text { Increase } \\
\text { Over } \\
\text { Base } \\
\end{array}$ \\
\hline $\begin{array}{r}0.0 \% \\
50.0 \% \\
75.0 \% \\
100.0 \%\end{array}$ & $\begin{array}{l}0.0 \% \\
0.0 \% \\
0.0 \% \\
0.0 \%\end{array}$ & $\begin{array}{l}57.6 \% \\
44.9 \% \\
38.6 \% \\
32.3 \%\end{array}$ & $\begin{array}{r}50,550 \\
25,275 \\
12,640 \\
\quad 0\end{array}$ & $\begin{array}{l}62,660 \\
62,660 \\
62,660 \\
62,660\end{array}$ & $\begin{array}{l}\text { 1990-94 Ave. } \\
\text { 1990-94 Ave. } \\
\text { 1990-94 Ave. } \\
\text { 1990-94 Ave. }\end{array}$ & $\begin{array}{l}10,100 \\
14,280 \\
16,385 \\
18,485\end{array}$ & $\begin{array}{r}65,700 \\
86,780 \\
97,315 \\
107,855\end{array}$ & $\begin{array}{r}0.0 \% \\
32.1 \% \\
48.1 \% \\
64.2 \%\end{array}$ \\
\hline $\begin{array}{l}50.0 \% \\
50.0 \% \\
50.0 \%\end{array}$ & $\begin{array}{l}20.0 \% \\
50.0 \% \\
80.0 \%\end{array}$ & $\begin{array}{l}47.2 \% \\
50.6 \% \\
53.9 \%\end{array}$ & $\begin{array}{l}25,275 \\
25,275 \\
25,275\end{array}$ & $\begin{array}{l}67,140 \\
73,860 \\
80,580\end{array}$ & $\begin{array}{l}1990-94 \text { Ave. } \\
\text { 1990-94 Ave. } \\
1990-94 \text { Ave. }\end{array}$ & $\begin{array}{l}13,540 \\
12,425 \\
11,310\end{array}$ & $\begin{array}{l}83,040 \\
77,440 \\
71,840\end{array}$ & $\begin{array}{r}26.4 \% \\
17.9 \% \\
9.3 \%\end{array}$ \\
\hline $\begin{array}{l}75.0 \% \\
75.0 \% \\
75.0 \%\end{array}$ & $\begin{array}{l}20.0 \% \\
50.0 \% \\
80.0 \%\end{array}$ & $\begin{array}{l}42.0 \% \\
47.1 \% \\
52.1 \%\end{array}$ & $\begin{array}{l}12,640 \\
12,640 \\
12,640\end{array}$ & $\begin{array}{l}69,380 \\
79,460 \\
89,530\end{array}$ & $\begin{array}{l}\text { 1990-94 Ave. } \\
\text { 1990-94 Ave. } \\
\text { 1990-94 Ave. }\end{array}$ & $\begin{array}{l}15,270 \\
13,595 \\
11,920\end{array}$ & $\begin{array}{l}91,715 \\
83,310 \\
74,910\end{array}$ & $\begin{array}{l}39.6 \% \\
26.8 \% \\
14.0 \%\end{array}$ \\
\hline $\begin{array}{l}100.0 \% \\
100.0 \% \\
100.0 \%\end{array}$ & $\begin{array}{l}20.0 \% \\
50.0 \% \\
80.0 \%\end{array}$ & $\begin{array}{l}36.8 \% \\
43.5 \% \\
50.2 \%\end{array}$ & $\begin{array}{l}0 \\
0 \\
0\end{array}$ & $\begin{array}{l}7 \overline{1,620} \\
85,055 \\
98,490\end{array}$ & $\begin{array}{l}\text { 1990-94 Ave. } \\
\text { 1990-94 Ave. } \\
\text { 1990-94 Ave. }\end{array}$ & $\begin{array}{l}16,995 \\
14,765 \\
12,530\end{array}$ & $\begin{array}{r}100,384 \\
-89,180 \\
77,980\end{array}$ & $\begin{array}{l}52.8 \% \\
35.7 \% \\
18.7 \%\end{array}$ \\
\hline $\begin{array}{r}0.0 \% \\
50.0 \% \\
75.0 \% \\
100.0 \%\end{array}$ & $\begin{array}{l}0.0 \% \\
0.0 \% \\
0.0 \% \\
0.0 \%\end{array}$ & $\begin{array}{l}57.6 \% \\
46.6 \% \\
41.1 \% \\
35.6 \%\end{array}$ & $\begin{array}{r}44,070 \\
22,035 \\
11,015 \\
0\end{array}$ & $\begin{array}{l}69,155 \\
69,155 \\
69,155 \\
69,155\end{array}$ & $\begin{array}{l}\text { 1986-90 Ave. } \\
\text { 1986-90 Ave. } \\
\text { 1986-90 Ave. } \\
1986-90 \text { Ave. }\end{array}$ & $\begin{array}{l}3,470 \\
5,275 \\
6,180 \\
7,085\end{array}$ & $\begin{array}{r}72,310 \\
92,535 \\
102,650 \\
112,760\end{array}$ & $\begin{array}{r}0.0 \% \\
28.0 \% \\
42.0 \% \\
55.9 \%\end{array}$ \\
\hline $\begin{array}{l}50.0 \% \\
50.0 \% \\
50.0 \%\end{array}$ & $\begin{array}{l}20.0 \% \\
50.0 \% \\
80.0 \%\end{array}$ & $\begin{array}{l}48.7 \% \\
51.8 \% \\
54.9 \%\end{array}$ & $\begin{array}{l}22,035 \\
22,035 \\
22,035\end{array}$ & $\begin{array}{l}73,315 \\
79,560 \\
85,805\end{array}$ & $\begin{array}{l}\text { 1986-90 Ave. } \\
\text { 1986-90 Ave. } \\
\text { 1986-90 Ave. }\end{array}$ & $\begin{array}{l}4,935 \\
4,420 \\
3,910\end{array}$ & $\begin{array}{l}88,715 \\
82,985 \\
77,255\end{array}$ & $\begin{array}{r}22.7 \% \\
14.8 \% \\
6.8 \%\end{array}$ \\
\hline $\begin{array}{l}75.0 \% \\
75.0 \% \\
75.0 \%\end{array}$ & $\begin{array}{l}20.0 \% \\
50.0 \% \\
80.0 \%\end{array}$ & $\begin{array}{l}44.2 \% \\
48.9 \% \\
53.6 \%\end{array}$ & $\begin{array}{l}11,015 \\
11,015 \\
11,015\end{array}$ & $\begin{array}{l}75,395 \\
84,760 \\
94,125\end{array}$ & $\begin{array}{l}\text { 1986-90 Ave. } \\
\text { 1986-90 Ave. } \\
1986-90 \text { Ave. }\end{array}$ & $\begin{array}{l}5,670 \\
4,900 \\
4,130\end{array}$ & $\begin{array}{l}96,920 \\
88,320 \\
79,725\end{array}$ & $\begin{array}{l}34.0 \% \\
22.1 \% \\
10.3 \%\end{array}$ \\
\hline $\begin{array}{l}100.0 \% \\
100.0 \% \\
100.0 \%\end{array}$ & $\begin{array}{l}20.0 \% \\
50.0 \% \\
80.0 \%\end{array}$ & $\begin{array}{l}39.7 \% \\
46.0 \% \\
52.2 \%\end{array}$ & $\begin{array}{l}0 \\
0 \\
0\end{array}$ & $\begin{array}{r}77,480 \\
89,965 \\
102,450\end{array}$ & $\begin{array}{l}\text { 1986-90 Ave. } \\
\text { 1986-90 Ave. } \\
\text { 1986-90 Ave. }\end{array}$ & $\begin{array}{l}6,400 \\
5,375 \\
4,350\end{array}$ & $\begin{array}{r}105,120 \\
93,660 \\
82,195\end{array}$ & $\begin{array}{l}45.4 \% \\
29.5 \% \\
13.7 \%\end{array}$ \\
\hline
\end{tabular}

a) Assumptions: 200,000 URB, 1,000 SRVV run size, 6,000 Deschutes turn off, 2,000 lower river sport, 3,000 Hanford sport, and Treaty Indian at $50 \%$; non-Indian at $40 \%$ of URB harvestable surplus at base harvest rate of $48.6 \%$ on SRW (1986-90 average harvest rate) and differential URB and SRW harvest rates documented in historical fisheries.

b/ $1990-94$ average conversion: Bonneville-McNary $=.8339$. 1986-90 average conversion: Bonneville-McNary $=.9197$. 


\section{ACKNOWLEDGEMENTS}

Acknowledgements are due to contributors to various portions of this report and the project in whole. Ron Roler and Joe Hymer of WDFW provided Chapter 8 . Mark Kaufman (WDFW) is responsible for the water quality sections of Chapter 2, as well as the water quality / macroinvertebrate sampling program. Robert Brooks (ODFW) worked closedly with Mark in water quality / macroinvertebrate field sampling.

Additional credit is due to Salmon for All for their constant support, and to CEDC staff personnel for field support. 


\section{REFERENCES}

Bonneville Power Administration (BPA). 1993. Youngs Bay Salmon Rearing and Release Program, Final Environmental Assessment.

British Columbia Ministry of Environment,-Lands and Parks. No date reported. Live Capture Techniques for Pacific Salmon. Prepared by Triton Environmental Consultants, LTD:

Clark, Les 1994. Personal communication. Gillnet fisherman, Chinook, Washington.

Durkin, J.T.; Coley, T.C.; Verner, K.; Emmett, R.L. 1981. An aquatic species evaluation at four self scouring sites in the Columbia River Estuary. Final Rep. to U.S. Army Corps of Eng. by U.S. Nat. Mar. Fish. Serv., Seattle, WA. Pp. 46.

Durkin, J.T., Emmett, R.L. 1980. Benthic invertebrates, water quality, and substrate texture in Baker Bay, Youngs Bay, and adjacent areas of the Columbia River Estuary. Final Rep. to U.S. Fish Wild. Serv. by U.S. Nat. Mar. Fish. Serv., Seattle,WA. Pp. 44 plus appendices.

Durkin, J.T., Emmett, R.L.; Verner, K.; Coley, T.C.; Muir, W.; McCabe, G.T., Jr.; McConnell, R. J.' 1982. Benthic macroinvertebrates and substrate of Cathlamet Bay, OR. Final Rep. to U.S. Fish Wild. Serv. by U.S. Nat. Mar. Fish. Serv. Seattle, WA. Pp. 87.

Durkin, J.T.; McCabe, G.; Coley, T.; McConnell, R.; Emmett, R.; Muir, W. 1981. Columbia River Estuary Data Development Program report: salmonid and non-salmonid fish. Vancouver, WA: Pacific Northwest River Basins Commission.

Emmett, R.L.; McCabe, G.T., Jr.; Coley, T.C.; McConnell, R.J.; Muir, W.D. 1986. Benthic sampling in Cathlamet Bay, Oregon--1984. Final Rep. to U.S. Army Corps of Eng. by U.S. Nat. Mar. Fish. Serv. Seattle, WA. Pp. 11 plus appendices.

English, T.S.; Daly,-D.L.; Heron, G.A.; Stahl, L.L. 1984. Draft report: zooplankton and larval fishes of the Columbia River Estuary. Astoria, OR: Columbia River Estuary Data Development Program.

Evergreen Pacific Publishing. 1991. River Cruising Atlas, Columbia, Snake Willamette. $107 \mathrm{pp}$. 
Fuss,H.W.; Fuller, R.; Kimbel, M.A.; Appleby, A.E.; Hammer, S.A.; Doty, D.; and Ashbrook, C. 1994.Annual Coded Wire Tag Program (Washington) Missing Production Groups. Annual Report 1994. Washington Department of Fisheries. Prepared for U.S. Department of Energy, Bonneville Power Administration. December 1994.

Garrison, R.L.; Issac, D.L.; Lewis, M.A.; Murray, W.A. 1994. Annual Coded-Wire Tag Program Oregon Missing Production Groups. Annual Report 1993. Oregon Department of Fish and Wildlife. Prepared for U.S. Department of Energy. Bonneville Power Administration.

Gretchell, R. 1988. Environmental Effects of Salmon Farming. Maine Department of Marine Resources. $8 \mathrm{pp}$.

Grimes, J. 1994. . Comparisons between Hanford Reach Wild and Priest Rapids Hatchery Fall Chinook Tag Groups, 1986-1991. WDFW - Columbia River Laboratory Progress Report 94-27. November, 1994.

Groot, C. and Margolis, L., 1991. Pacific Salmon Life Histories. UBC Press, Vancouver.

Hogan, James. 1994. Personal communication. Gillnet Fisherman, Clatskanie, Oregon.

Holton, R.L.; Higley, D.L.; Brzezinski, M.A.; Jones, K.K.; Wilson, S.L. 1984. Benthic infauna of the Columbia River Estuary. Astoria, OR: Columbia River Estuary Data Development Program.

Homolka, Ken. 1994. Personal Communication. ODFW.Research, Springfield, Oregon.

Kreps, Terry D. 1994: Personal Communication. Pathologist, Oregon Department of Fish and Wildlife.

McCabe, G.T., Jr.; Hinton, S.A.; Emmett, R.L.; McConnell; R.J. 1990. Benthic invertebrates, sediment characteristics, and demersal fishes off Cottonwood Island, Columbia River, before and after rock groin construction, 1987-1988. Final rep. to U.S. Army Corps of Eng. By U.S. Nat. Mar. Fish. Serv: Seattle, WA. Pp. 17 plus appendices.

Marincovich, Jack. 1994. Personal communication. Gillnet fisherman, Astoria, Oregon. 
McIntire, C.D.; Amspoker, M.C. 1984. Benthic primary production in the Columbia River Estuary. Astoria, OR: Columbia River Estuary Data Development Program.

ODFW \& WDFW. 1993. Biological Assessment of the Impacts of Anticipated 1993 Fall Season Columbia River and Mainstem Tributary Fisheries on Listed Snake River Salmon Species Under the Endangered Species Act. Columbia River Technical Staffs, A subgroup of the Technical Advisory Committee. April 19, 1993.

ODFW (Oregon Department of Fish and Wildlife). 1994. Staff Report: A proposal to increase Rogue River Bright Fall Chinook in the Lower Columbia River. September 28, 1994.

ODFW (Oregon Department of Fish and Wildlife). 1994. Staff Report: Youngs Bay Fall Salmon Fishery. July 20, 1994.

Pacific Salmon Commission (PSC). 1995. Ad-Hoc Selective Fishery Evaluation Committee. Selective Fishery Evaluation. June 9, 1995.

Pedersen, Art. 1994. Personal communication. Gillnet fisherman, Cathlamet, Washington.

Seaman, M.H.; ed. 1977. Columbia River Estuary: inventory of physical, biological and cultural characteristics. Astoria, OR: Columbia River Estuary Study Taskforce.

Simenstad, C.A. 1984. Epibenthic organisms of the Columbia River Estuary. Astoria, OR: Columbia River Estuary Data Development Program.

Simenstad, C.A.; Jay, D.; Mclntire, C.D.; Nehlsen, W.; Sherwood, C.R.; Small, L.F. 1984. The dynamics of the Columbia River Estuarine ecosystem, volumes I and II. Astoria, OR: Columbia River Estuary Data Development Program.

Smith, Stephen; Hirose, P.; Miller, M.; Hill, J. 1994. Potential Lower Columbia River terminal salmon fisheries, Interim Report. July, 1994.

Takalo, Alan 1994. Personal communication. Gillnet fisherman, Astoria, Oregon.

Tetra Tech Inc. 1993. Reconnaissance survey of the lower Columbia River: Final report to the Bi-State Water Quality Program.

Warren, James W. 1991. Diseases of hatchery fish. U.S. Fish and Wildlife Service. 
Pacific Region sixth edition.

WDF (Washington Department of Fisheries). 1993. Run Size Forecast of the Return of Columbia River Fall Chinook Salmon Stocks in 1993. Columbia River Laboratory Progress Report 93-09. March 1, 1993.

WDFW \& ODFW 1993. Joint staff report concerning stock composition estimates of the 1993 lower Columbia River spring chinook fisheries. December, 1993.

WDFW \& ODFW. 1994. Status Report. Columbia River Fish Runs and Fisheries, 1938-93. August, 1994.

Weston, D.P. 1986. The environmental effects of floating mariculture in Puget Sound. Prepared by the University of Washington, School of Oceanography, for the Washington Departments of Fisheries and Ecology. 148 pp. 


\section{APPENDIX 1. COLUMBIA RIVER: TERMINAL FISHERIES RESEARCH PROJECT}

1993-94 GOALS AND OBJECTIVES

I. Survey and categorize potential terminal fishing sites in the Columbia River basin for basic physical characteristics (high, medium and low).

A. Identify offchannel sites and adjacent mainstem river areas with any basic potential for known stock fishing based on criteria established via expert opinion.

1. Review pertinent gray literature, such as casual data collections, memos, etc., related to harvest, production and water quality.

2. Meet with lower river commercial fishery representatives, through Salmon for All (SFA), to brainstorm locations and criteria.

3. Develop criteria and submit to BPA and SFA for 2-week coordination review, then finalize criteria.

B. Categorize and rank potential sites into three groups - low, medium, and high potential based on criteria from above.

C. Describe and map the basic physical dimensions and water flow characteristics of those high (and medium) sites relative to a terminal fishing site; using survey equipment, water quality equipment, and depth recorders.

II. Determine the capability of the medium and high terminal fishing sites for rearing and acclimating anadromous fish species in net pens or other facilities.

A. Review existing literature on water quality (temperature, D.O., water born contaminants, flushing flows, etc.), in the high (and medium) terminal sites (or adjacent waters to which fish would return after passing through a terminal fishing site) for the period October-May.

B. Conduct water quality monitoring program for rearing areas in the high (and medium) terminal sites (or adjacent waters to which fish would return after passing through a terminal fishing site) for the period October-May as necessary pending above results.

C. Determine the homing capability of the high and medium sites to effectively attract returning adults.

1. Review homing and straying literature and on-going experiments for stock transfers; project homing probabilities for each site.

D. Using agency experts, evaluate the potential for fish disease and pathogen problems for rearing/release locations associated with the high and medium terminal sites.

1. Review literature and on-going experiments relative to disease/net pen relationships; project disease problem probabilities for each site.

III. Determine the capability of the medium and high terminal fishing sites to allow manageable and economically competetitive harvest of returning fish.

A. Meet with SFA group to consult on definitions, criteria, and descriptions of items in tasks II: $B, C$, and $D$. 
B. For the high (and medium) sites, determine the water area of sufficient depth (or other characteristics) available for use by commercial fishers using standard or modified gear, using data from task I:C.

C. Determine the number of boats and/or individuals high (and medium) sites could accommodate under conventional cooperative fishing rules.

D. Assess the bottom characteristics, particularly snags, and flow characteristics pertinent to effective fishing. Identify any costs for necessary modifications to allow for improved fishing (e.g. snag clearing).

1. Survey areas for snags or other correctable impediments to fishing using recording depth finder and drag lines or cargo netting: map problem areas.

2. Identify costs of one-time snag clearing and probability, costs, and frequency of future snag clearing.

E. Describe any other issues, both positive and negative, on the high (and medium) sites that would affect fishing.

F. Evaluate applications of various fishing gear types to terminal sites. Upon development of new live-capture fishing gear per the Selective Gear Research Project, integrate this knowledge into the use of identified terminal fishing sites. IV. For the high (and medium) terminal fishing sites, determine the potential for harvest of target and non-targeted fishing species.

A. Conduct test fisheries (netting) in the high (and medium) sites during the spring and fall seasons to determine catch on target and non-targeted species and stocks.

1. Obtain NMFS agreement via consultations under the Endangered Species Act for test fishing prior to initiating fishing. Submit NMFS approval to BPA.

2. Contract with test fishermen through a bidding process.

3. Develop a test fishing schedule.

4. Prepare terminal site for test fishing (snag removal in limited areas).

5. Conduct fisheries sampling for CWT recovery and other biological data. Investigate feasibility of genetic stock identification.

6. Analyze results, write report.

V. Evaluate the suitability of various anadromous fish stocks for use in the high (and medium) terminal fishing sites.

A. Evaluate the economic desirability and feasibility of various fish stocks to the fisher, processor, and marketplace.

B. Evaluate genetic and other compatibility issues of various fish stocks with local native populations by comparing life history characteristics and estimating potential of deleterious crossbreeding or competitive impacts.

1. Review Oregon Wild Fish Stock Management Policy and Washington

Salmon and Steelhead Stock Inventory status reports; meet with appropriate staff.

2. Coordinate with NMFS on potential ESA concerns.

C. Evaluate the availability, including timeframe, of various fish stocks (production from hatcheries) for use in a terminal fishery program; (take into 
account information from $V: A$ and $V: B$.

D. Evaluate the need for any new production and describe necessary processes to attain approval of new production.

E. Evaluate effects of overwintering rearing of Willamette River spring chinook in Youngs Bay on survival, contribution to fisheries, and straying; ' 93 , '94, and '95 broods.

1. Obtain NMFS agreement via ESA consultation and submit to BPA prior to June, 1994.

2. Obtain eggs sufficient for, and rear 475,000 Willamette spring chinook salmon to a size of 25 fish per pound at existing facility with sufficient rearing space; ' 93 , ' 94 , and ' 95 broods.

3. Transfer 425,000 Willamette spring chinook salmon at 25 fish per pound to Youngs Bay net pens in November, 1994, (150,000 CWT; six groups of 25,000).

4. Transfer 50,000 Willamette spring chinook salmon at 25 fish per pound to CEDC's South Fork Klaskanine facility, November 1994 (50,000 CWT; two groups of 25,000).

5. Rear 125,000 fish from November 1994 to a size of 8 fish per pound in Youngs Bay net pens and release February 1, 1995 (50;000 CWT), two groups of 25,000).

6. Rear 150,000 fish from November 1994 to a size of 8 fish per pound in Youngs Bay net pens and release March 1, 1995 (50,000 CWT; two groups of 25,000 ).

7. Rear 50,000 fish from November 1994 to a size of 8 fish per pound in South Fork facility and release March 1, 1995 (50,000 CWT; two groups of 25,000).

8. Rear.150,000 fish from November 1994 to a size of 5 fish per pound in Youngs Bay net pens and release April 1; 1995 (50,000 CWT; two groups of 25,000).

9. Repeat E:1 and E:2 for 1994 and 1995 broods.

10. Design a plan for evaluation of straying and recover coded-wire tags in Youngs Bay drainage.

11. Secure fisherman assistance in any construction of net pens and other task activities. Continue fisherman and processor donations from landings of spring chinook in Youngs Bay to assist in net pen rearing costs.

VI. Determine the generic costs and logistics of a large-scale net pen rearing program (overwinter rearing and short-term acclimation) and estimate the variables for each of the medium- and high-terminal fishing sites.

A. Estimate production capabilities of each terminal fishing location in high (and medium) categories.

B. Determine unit costs, capital, and O\&M, of short term acclimating and overwinter rearing each potential species for each terminal fishery location. 
C. Based on VI:A and B, describe the costs, capital, and O\&M, and basics of a range of potential terminal fishing programs, with costs phased in over time toward a final program.

VII. Evaluate the effects of a large-scale net pen rearing program (overwinter rearing and short-term acclimation) for terminal fishing on hatchery production programs.

A. From V:E and VI:B, and in consultation.with NMFS, describe the effects of a range of terminal fishery programs on hatchery production programs, including any capital costs, changes on 0\&M costs, and potential changes and efficiencies in production programs/facilities.

VIII. Determine the effects on upriver fish runs, escapements, and Zone 6 fisheries of shifting various levels of historical Zone $1-5$ commercial fisheries to terminal sites.

A. Describe the effect of maintaining historic level (base case), $100 \%, 50 \%, 25 \%$, and $0 \%$ of base case mainstem Żone 1-5 fisheries on passage of upriver runs of anadromous salmonids when terminal fisheries are in operation.

B. Of upriver fish runs saved in VIII:A, describe effects of allocating $20 \%, 50 \%$ and $80 \%$ of these savings to Zone 6 or other Indian fisheries and to escapement.

IX. Coordinate activities with ODFW, WDFW, CEDC, BPA, National Marine Fisheries Service, and Salmon for All.

A. Ensure all objectives, tasks, and activities undertaken by WDFW \& ODFW are fully coordinated to ensure complementary products and minimal overlap of actions.

B. Co-host bimonthly coordination meetings of involved or interested parties to further develop work plans and report on progress. 
Appendix 2. Raw sample data from 1994 spring test fishery, in numbers of fish and hours fished by species, site, date, and time.

\begin{tabular}{|c|c|c|c|c|c|c|c|c|c|c|c|c|c|c|c|c|c|}
\hline $\begin{array}{l}\mathrm{D} \\
\mathrm{A} \\
\mathrm{T} \\
\mathrm{E}\end{array}$ & $\begin{array}{l}S \\
\text { I } \\
T \\
E\end{array}$ & $\begin{array}{l}\mathrm{D} \\
\mathrm{R} \\
\mathrm{I} \\
\mathrm{F} \\
\mathrm{T} \\
\end{array}$ & $\begin{array}{l}\mathbf{N} \\
\mathbf{E} \\
\mathbf{T}\end{array}$ & $\begin{array}{l}\mathrm{L} \\
\mathrm{E} \\
\mathrm{N} \\
\mathrm{T} \\
\mathrm{H}\end{array}$ & Time & Hrs & \begin{tabular}{cc}
\multicolumn{1}{c}{$\mathrm{CH}$} \\
White \\
$\mathrm{L}$ & $\mathrm{D}$ \\
$\mathrm{I}$ & $\mathrm{E}$ \\
$\mathrm{V}$ & $\mathrm{A}$ \\
$\mathrm{E}$ & $\mathrm{D}$
\end{tabular} & $\begin{array}{l}\text { IINC } \\
\frac{e}{D} \\
\text { E } \\
A \\
D\end{array}$ & $\begin{array}{c}\text { OOK } \\
\text { Blac } \\
L \\
\text { I } \\
\text { V } \\
\text { E }\end{array}$ & $\begin{array}{l}\frac{k}{\mathrm{k}} \\
\mathrm{D} \\
\mathrm{E} \\
\mathrm{A} \\
\mathrm{D}\end{array}$ & $\begin{array}{l}\text { Sth } \\
\text { L } \\
\text { V } \\
\text { E } \\
\end{array}$ & $\begin{array}{l}\text { Id } \\
D \\
E \\
A \\
D\end{array}$ & $\begin{array}{l}\text { Stg } \\
W \\
\mathrm{H} \\
\mathrm{I} \\
\mathrm{T} \\
\mathrm{E}\end{array}$ & $\begin{array}{c}\mathbf{n} \\
\mathbf{G} \\
\mathbf{R} \\
\mathrm{E} \\
\mathrm{E} \\
\mathbf{N} \\
\end{array}$ & $\begin{array}{l}\mathrm{S} \\
\mathrm{H} \\
\mathrm{A} \\
\mathrm{D}\end{array}$ & Comments & \\
\hline$\overline{420}$ & WA & 2 & 2 & 50 & 23.92 & 0.83 & 1 & & & & & & & & & & \\
\hline 420 & WA & 3 & 1 & 153 & 25.03 & 1.47 & & 1 & & 1 & & & 582 & & 1 & & \\
\hline 427 & WA & 1 & 2 & 150 & 7.38 & 1.02 & 4 & & & & & & 21 & & & & \\
\hline 427 & WA & 1 & 2 & 150 & 8.63 & 0.90 & & 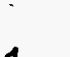 & & & & & 6 & & & & \\
\hline 427 & WA & 1 & 1 & 153 & 9.65 & 0.60 & 41 & 1 & & $i$ & & & - 19 & & 1 & & \\
\hline 427 & WA & 1 & 1 & 153 & 10.40 & 0.68 & & & & & & & $\begin{array}{l}7 \\
1\end{array}$ & & & & \\
\hline $\begin{array}{l}505 \\
505\end{array}$ & $\begin{array}{l}\text { WA } \\
\text { WA }\end{array}$ & $\begin{array}{l}2 \\
3\end{array}$ & $\begin{array}{l}2 \\
2\end{array}$ & $\begin{array}{l}55 \\
50\end{array}$ & $\begin{array}{l}0.12 \\
0.80\end{array}$ & $\begin{array}{l}0.47 \\
0.47\end{array}$ & & & & & & & $\begin{array}{l}1 \\
7\end{array}$ & & & & \\
\hline 505 & WA & 1 & 2 & 100 & 1.67 & 0.95 & & & & & & & 24 & & & & \\
\hline 505 & WA & 1 & 1 & 105 & 2.93 & 1.17 & & 1 & & & & & 48 & & 2 & & \\
\hline 511 & WA & 1 & 2 & 150 & 8.50 & 1.17 & & & & & & & 34 & & & & \\
\hline 511 & WA & 1 & 1 & 153 & 9.92 & 0.87 & & & & & & & 51 & & & & \\
\hline 511 & WA & 1 & 1 & 153 & 10.95 & 0.97 & & - & & & & & 32 & & 1 & & \\
\hline 518 & WA & 3 & 2 & 150 & 22.27 & 0.95 & & & & & & & 5 & & & & \\
\hline 518 & WA & 1 & 1 & 153 & 23.50 & 1.65 & & & $=$ & & & & 122 & & 1 & & \\
\hline 518 & WA & 1 & 1 & 153 & 25.35 & 1.42 & & & & & & & 85 & & 1 & & \\
\hline 525 & WA & 1 & 2 & 150 & 8.23 & 1.02 & & & & & & & 5 & & & & \\
\hline 525 & WA & 1 & 1 & 153 & 9.42 & 1.23 & 1 & & & & 1 & & 22 & & 3 & & \\
\hline$\underline{525}$ & WA & 1 & 1 & 153 & 10.75 & 1.33 & & & & & & & 28 & & 3 & & \\
\hline 421 & TP & 1 & 2 & 125 & 21.10 & 0.48 & & & & & & & 1 & & & & \\
\hline 421 & TP & 1. & 2 & 250 & 21.65 & 0.62 & & & & & & & 3 & & & & \\
\hline 421 & TP & 2 & 2 & 125 & 22.45 & 0.65 & & & & & & & 1 & & & & \\
\hline 421 & TP & 4 & 1 & 125 & 23.42 & 0.83 & & & & & & & 3 & & & & \\
\hline 428 & TP & 2. & 2 & 255 & 9.35 & 0.88 & & & & & & & & & & & \\
\hline 428 & TP & 4 & 2 & 260 & 10.35 & 0.97 & & & & & & 1 & 6 & & & - & \\
\hline 428 & TP & 3 & 1 & 200 & 11.48 & 0.80 & & & & & & & & & 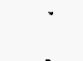 & & \\
\hline 505 & $\mathrm{TP}$ & 3 & 2 & 250 & 21.67 & 0.83 & & & & & & & & & 1 & & \\
\hline 505 & TP & 4 & 2 & 250 & 22.68 & 0.90 & & & & & - & & 2 & & 1 & & \\
\hline 505 & TP & 1 & 1 & 200 & 23.78 & 0.85 & & & & & & & 1 & & & & \\
\hline 512 & TP & 4 & 2 & 150 & 8.22 & 0.53 & & & & & & & 24 & & & & \\
\hline 512 & TP & 3 & 2 & 125 & 8.83 & 0.92 & & & & & & & & & & & \\
\hline 512 & TP & 1 & 1 & 105 & 9.83 & 0.68 & & & & & & & & & & & \\
\hline 512 & TP & 1 & 1. & 200 & 10.58 & 0.47 & & & & & & & 11 & & & & \\
\hline 519 & TP & 3 & 2 & 125 & 20.12 & 0.77 & & & & & 1 & 1 & & & 2 & & \\
\hline 519 & TP & 2 & 2 & 125 & 20.98 & 0.72 & & & & & & & & & 1 & & \\
\hline 519 & TP & 1 & 2 & 125 & 21.85 & 0.72 & & & & & & & & & & & \\
\hline 526 & TP & 3 & 1 & 200 & 8.23 & 0.73 & & & & & & & 1 & & & & \\
\hline $5 ?$ & TP & 4. & 1 & 200 & 9.05 & 0.87 & & - & & & & & 7 & & & & \\
\hline 526 & TP & 1 & 2 & 250 & 10.03 & 0.88 & & & & & & & 11 & & & & \\
\hline
\end{tabular}


Appendix 2.

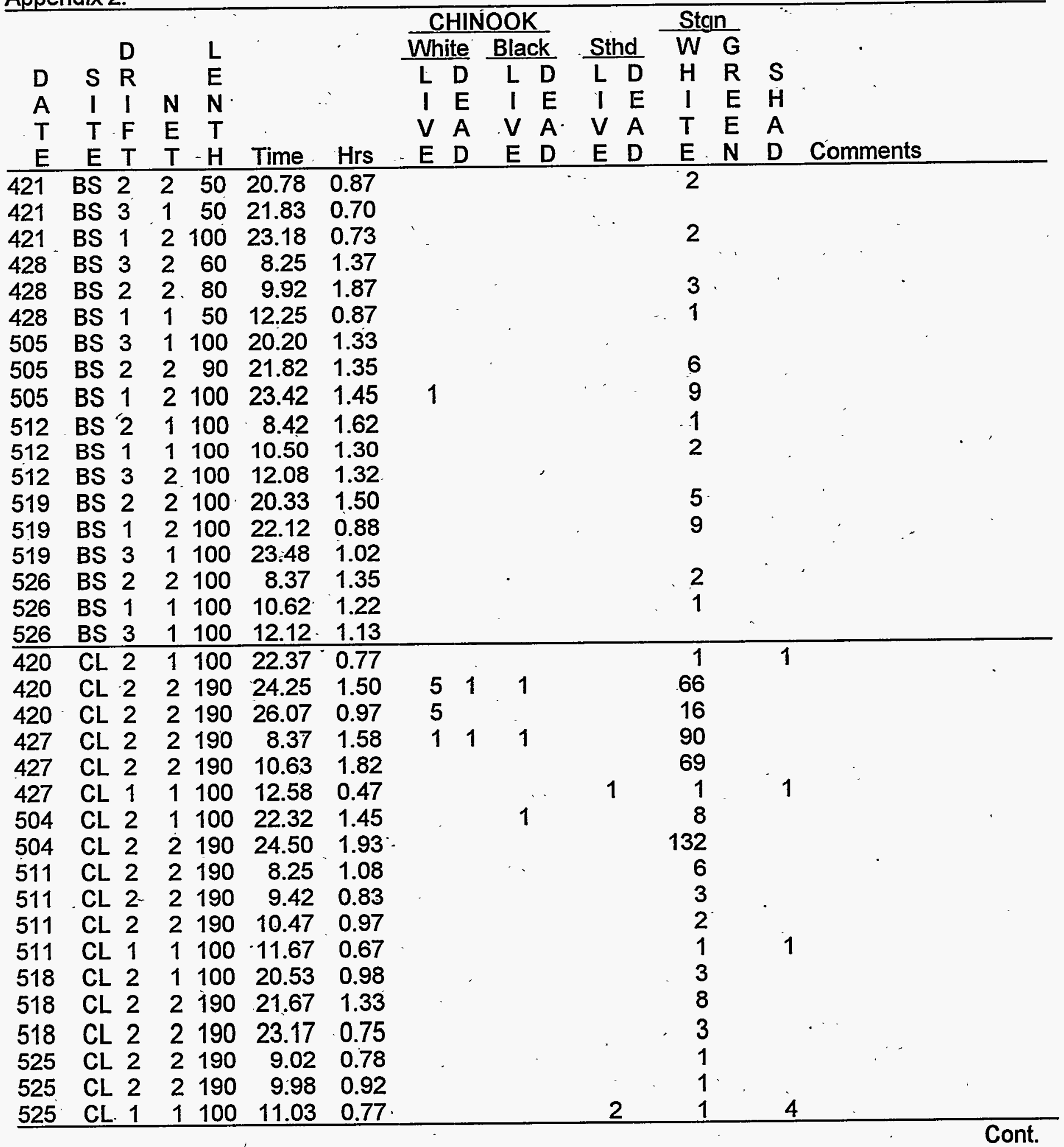


Appendix 2.

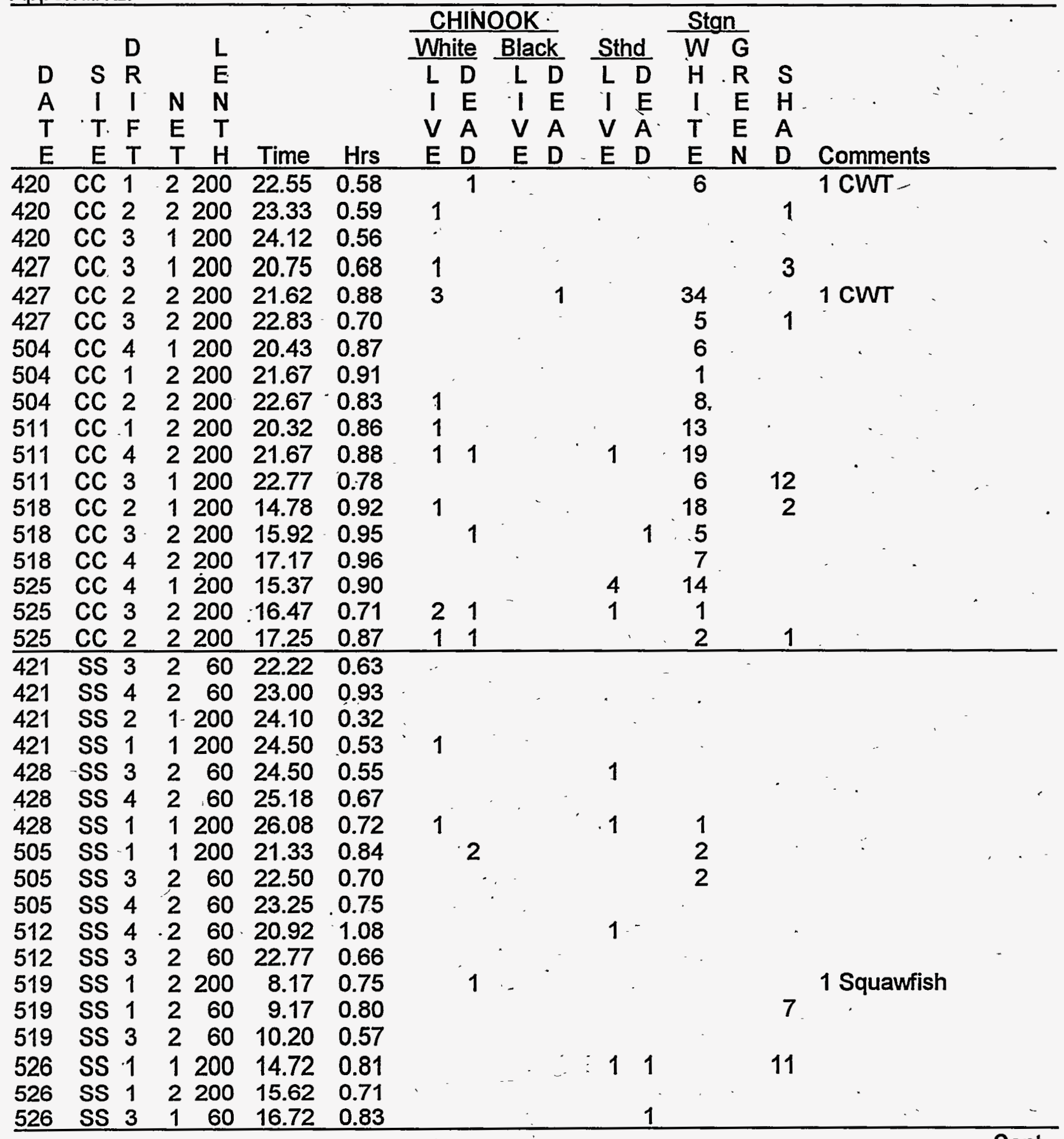


Appendix 2.

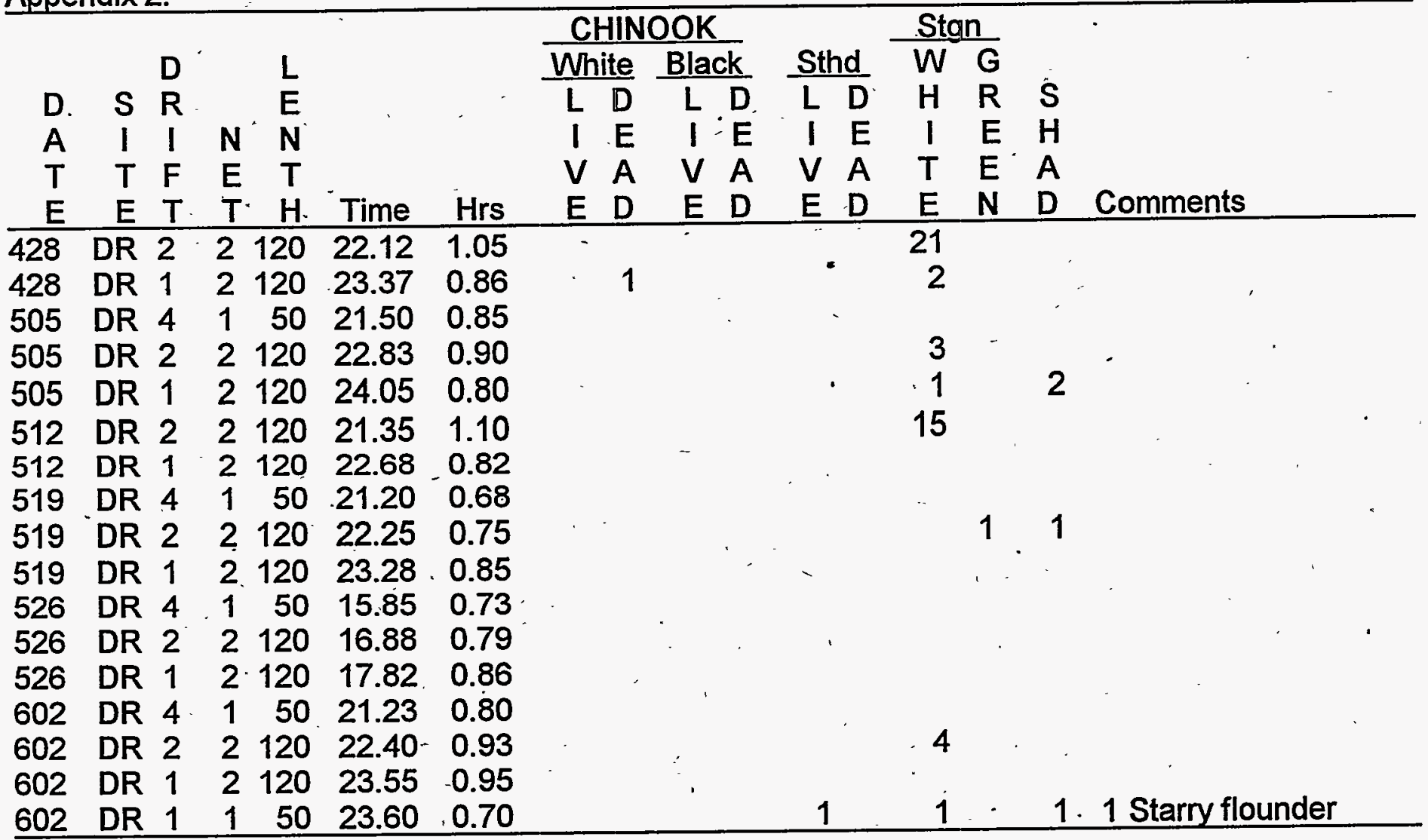

Notes:

Sites $B S=$ Blind Slough

$C C=$ Cathlamet Channel

$C L=$ Clifton Channel

$D R=$ Deep River/Grays Bay

$S S=$ Steamboat Slough/Skamokawa

$T P=$ Tongue Point

$W A=$ Wallace Slough

Drifts Numbered as in Figures 1-7.

Nets $1=$ Small mesh $\left(5-6^{\prime \prime}\right)$

$2=$ Large mesh (7-8")

Length Length of net in fathoms

Time Hour (and hundredth) that net was set based on 24-hour clock

Hrs Numbers of hours that net was fished, including half of both set and pull time.

Livel

Dead Condition of fish when pulled from net 
Appendix 3. Numbers of fish caught in fall, 1994, test fishery of terminal fishery program, by individual drift.

\begin{tabular}{|c|c|c|c|c|c|c|c|c|c|c|c|c|c|c|c|}
\hline $\begin{array}{l}D \\
A \\
T \\
E\end{array}$ & $\begin{array}{l}S \\
I \\
T \\
E\end{array}$ & $\begin{array}{l}D \\
R \\
I \\
F \\
T\end{array}$ & $\begin{array}{l}\mathbf{N} \\
\mathrm{E} \\
\mathbf{T}\end{array}$ & $\begin{array}{l}\mathrm{L} \\
\mathrm{E} \\
\mathrm{N} \\
\mathrm{T} \\
\mathrm{H}\end{array}$ & $\begin{array}{c}T \\
\mathrm{I} \\
\mathrm{M} \\
\mathrm{E}\end{array}$ & $\begin{array}{l}H \\
O \\
U \\
R \\
S\end{array}$ & $\begin{array}{l}\text { Chin } \\
\mathrm{L} \\
\mathrm{I} \\
\mathrm{V} \\
\mathrm{E}\end{array}$ & 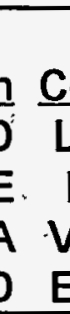 & $\begin{array}{l}\text { oho } \\
\mathrm{L} \\
\mathrm{I} \\
\mathrm{I} \\
\mathrm{B} \\
\mathrm{A}\end{array}$ & $\begin{array}{l}5 \\
\mathrm{~L}\end{array}$ & $\begin{array}{l}\text { Sthd } \\
\text { D D } \\
\text { I } \mathrm{E} \\
\mathrm{A} \\
\mathrm{D}\end{array}$ & $\begin{array}{cc}\text { Stgn } \\
\text { W } & \text { G } \\
H & R \\
1 & E \\
T & E \\
\text { E } & N\end{array}$ & $\begin{array}{l}S \\
H \\
A \\
D\end{array}$ & Comments & \\
\hline 924 & BS & 3 & 2 & 100 & 8.35 & 0.64 & & & & & & & & & \\
\hline 924 & BS & 2 & 1 & 100 & 9.40 & 1.14 & & & & & . & & & & \\
\hline 924 & BS & 1 & 2 & 100 & 11.42 & 0.63 & & & & & & & & & \\
\hline 929 & BS & 2 & 2 & 100 & 20.75 & 0.61 & & 2 & 2 & & & 2 & & & \\
\hline 929 & BS & 1 & 1 & 100 & 21.67 & 1.19 & & & & & & & & & \\
\hline 929 & BS & 3 & 1 & 100 & 23.25 & 0.72 & 1 & & & & & & & & \\
\hline 1006 & BS & 3 & 2 & 90 & 19.78 & 1.15 & & & & & & & & & \\
\hline 1006 & BS & 2 & 1 & 100 & 21.28 & 0.88 & & & & & & & & & \\
\hline 1006 & BS & 1 & 2 & 100 & 22.52 & 1.15 & & & & & & 2 & & & - \\
\hline 1014 & BS & 3 & 1 & 100 & 8.25 & 0.71 & & & & & & & & & \\
\hline 1014 & BS & 2 & 2 & 100 & 9.42 & 0.93 & & & & & & & & & \\
\hline 1014 & BS & 1 & 1 & 100 & 10.53 & 1.08 & & & & & & 1 & & 3 crayfish & \\
\hline 1020 & BS & 3 & 2 & 90 & 19.52 & 1.04 & & & & & & & & & \\
\hline 1020 & BS & 2 & 1 & 100 & 21.02 & 0.98 & & & & & & & & & \\
\hline 1020 & BS & 1 & 2 & 100 & 22.27 & 1.03 & 1 & & & & & 1 & & & \\
\hline 1027 & BS & 1 & 1 & 100 & 8.25 & 0.88 & & & & & & 1 & & & \\
\hline 1027 & BS & 2 & 2 & 100 & 9.33 & 1.13 & & & & & & & & & \\
\hline 1027 & BS & 3 & 1 & 100 & 10.92 & 0.63 & & & & & & & & & \\
\hline 921 & CC & 3 & 2 & 200 & 11.58 & 0.46 & & & & & & 1 & & & \\
\hline 921 & CC & 1 & 1 & 200 & 12.33 & 0.64 & 1 & & & & & 24 & & & \\
\hline 921 & CC & 2 & 2 & 200 & 13.33 & 0.58 & & & & & & 1 & & & \\
\hline 929 & CC & 1 & 2 & 200 & 21.00 & 0.58 & 2 & & & & & 10 & & & \\
\hline 929 & CC & 2 & 1 & 200 & 21.88 & 0.63 & & & & & & 13 & & & \\
\hline 929 & CC & 3 & 1 & 200 & 22.80 & 0.66 & & $=$ & & & & 12 & & & \\
\hline 1006 & CC & 3 & 2 & 200 & 24.13 & 0.50 & & & & & & 14 & & & \\
\hline 1006 & CC & 4 & 1 & 200 & 25.00 & 0.43 & & & ( & 1 & & 9 & & & \\
\hline 1006 & CC & 1 & 2 & 200 & 25.83 & 0.74 & & & 2 & $?$ & & 14 & & & \\
\hline 1014 & CC & 2 & 1 & 200 & 10.80 & 0.63 & & & & & 1 & & & & \\
\hline 1014 & CC & 4 & 1. & 200 & .11 .75 & 0.52 & & & & & & 3 & & & \\
\hline 1014 & CC & 3 & 2 & 200 & 12.67 & 0.53 & & & & & & 3 & & & - \\
\hline 1020 & CC & 3 & 1 & 200 & 23.05 & 0.60 & & 1 & 1 & & & 2 & & & \\
\hline 1020 & CC & 2 & 1 & 200 & 24.00 & 0.53 & & & & & & 2 & & & \\
\hline 1020 & CC & 1 & 2 & 200 & 24.78 & 0.43 & & & & & & 1 & & & \\
\hline 1027 & CC & 1 & 2 & 200 & 8.45 & 0.43 & & & & & & 2 & & & \\
\hline 1027 & CC & 4 & 1 & 200 & 9.25 & 0.54 & & & & & & 11 & & & \\
\hline 1027 & CC & 2 & 1 & 200 & 10.13 & 0.58 & & 1 & 1 & & & 1 & & & \\
\hline
\end{tabular}


Appendix 3.

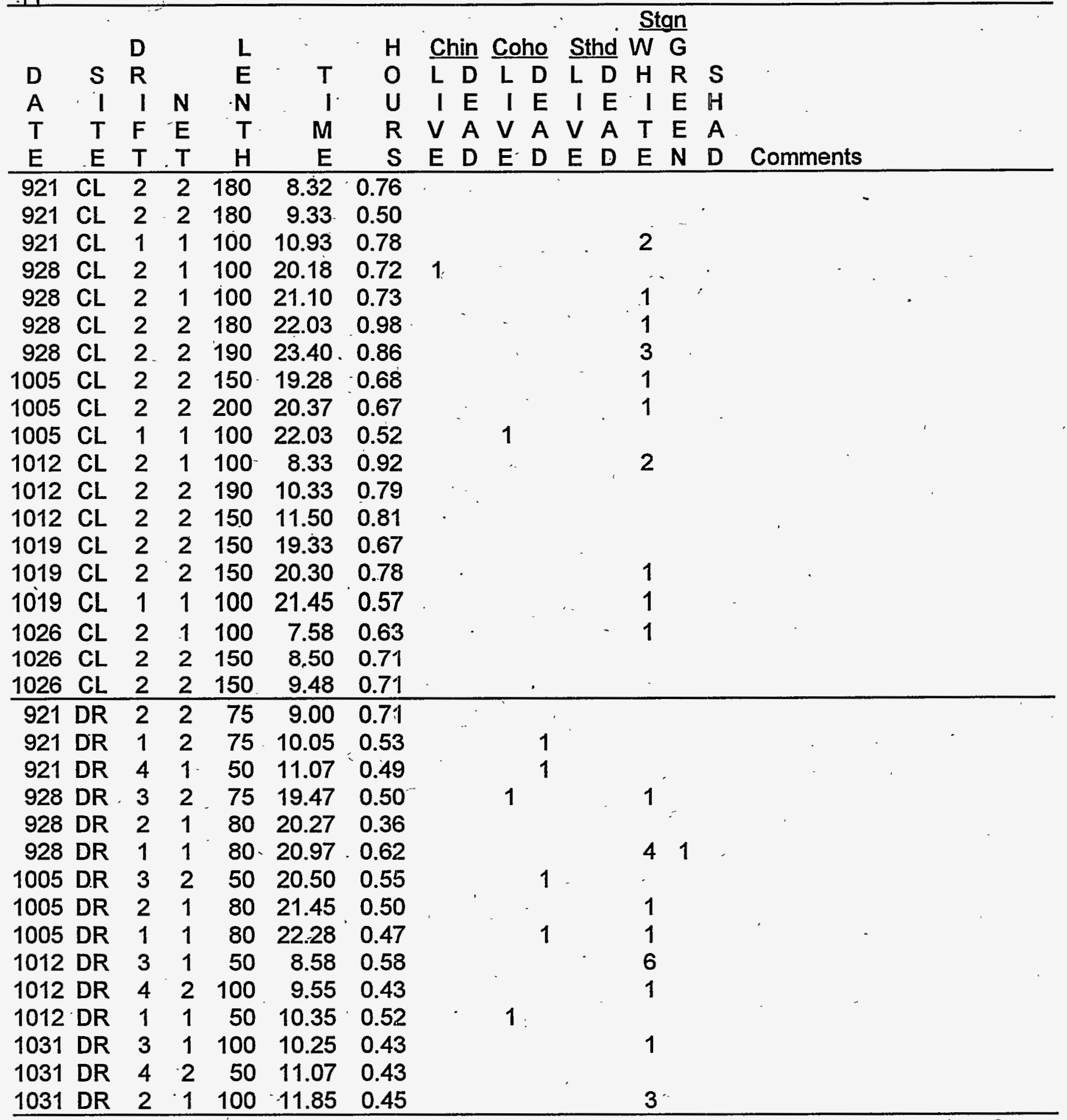




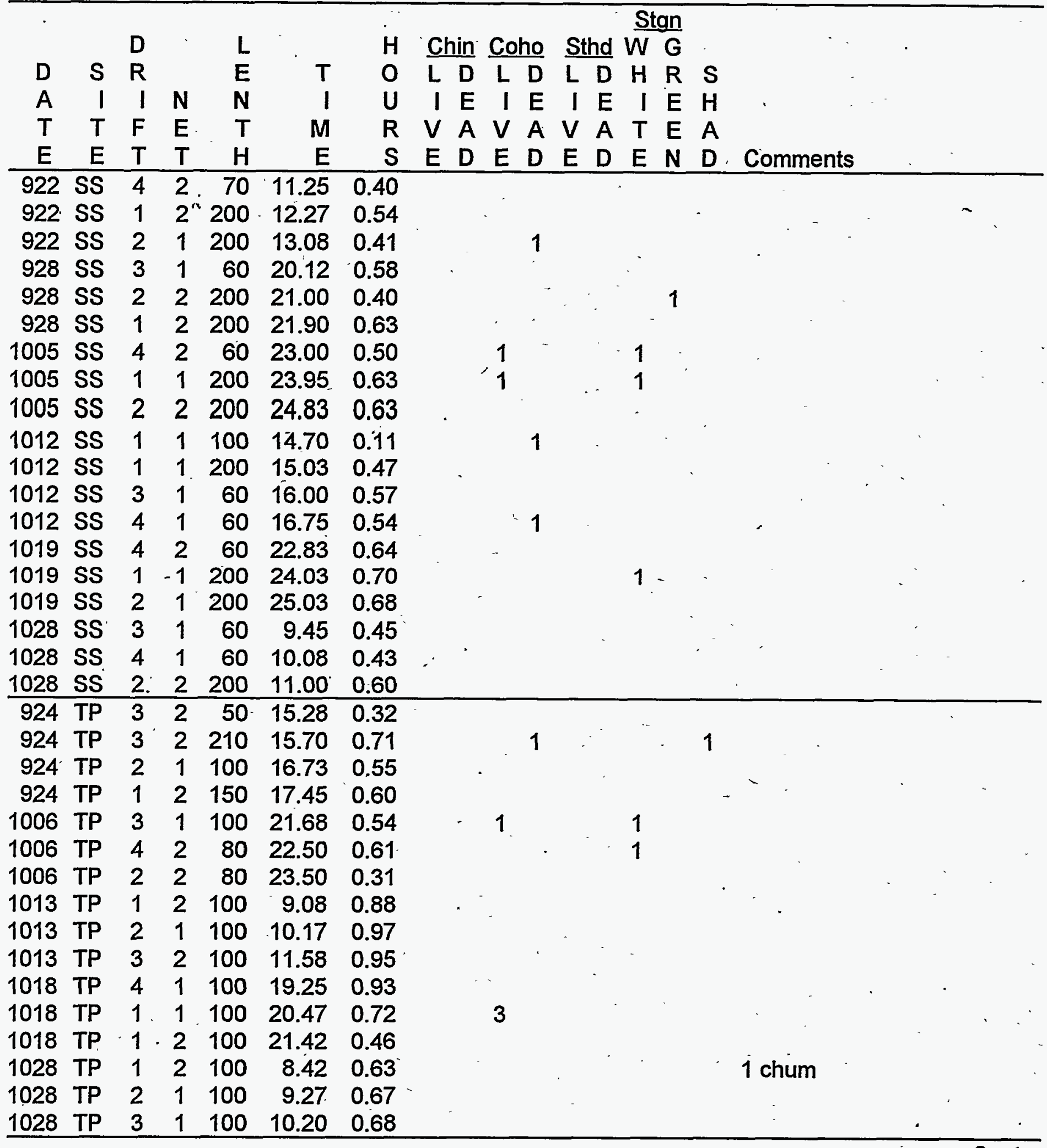




\begin{tabular}{|c|c|c|c|c|c|c|c|c|c|c|c|c|c|c|c|}
\hline $\begin{array}{l}D \\
A \\
T \\
E\end{array}$ & $\begin{array}{l}S \\
I \\
T \\
E\end{array}$ & $\begin{array}{l}D \\
R \\
\text { I } \\
F \\
T\end{array}$ & $\begin{array}{l}\mathbf{N} \\
\mathrm{E} \\
\mathrm{T}\end{array}$ & $\begin{array}{c}\mathrm{L} \\
\mathrm{E} \\
\mathrm{N} \\
\mathrm{T} \\
\mathrm{H}\end{array}$ & $\begin{array}{c}T \\
I \\
M\end{array}$ & $\begin{array}{l}H \\
O \\
U \\
R \\
S\end{array}$ & $\begin{array}{l}\frac{C r}{L} \\
I \\
V \\
E\end{array}$ & $\begin{array}{l}\frac{i n}{D} \\
E \\
A \\
D\end{array}$ & $\begin{array}{l}\text { Coh } \\
L \\
\text { L } \\
E\end{array}$ & & $\begin{array}{ll}\text { Sthd } \\
L & D \\
& E \\
V & A \\
E & D\end{array}$ & $\begin{array}{c}\mathrm{St} \\
\mathrm{W} \\
\mathrm{H} \\
\mathrm{I} \\
\mathrm{T} \\
\mathrm{E}\end{array}$ & $\begin{array}{c}\operatorname{tgn} \\
\mathrm{G} \\
\mathrm{R} \\
\mathrm{E} \\
\mathrm{E} \\
\mathrm{N}\end{array}$ & $\begin{array}{l}S \\
H \\
A \\
D\end{array}$ & Comments \\
\hline 921 & NA & 1 & 1 & 150 & 10.03 & 0.73 & & & & & & 12 & & & 1 stariy flounder \\
\hline 921 & NA & 1 & 2 & 150 & 11.18 & 0.65 & & & & & & & & & \\
\hline 921 & NA & 3 & 2 & 150 & 12.67 & 0.68 & & & & & 2 . & 2 & & & \\
\hline 928 & NA & 3 & 2 & 150 & 20.25 & 0.63 & & & & & & 2 & & 1 & 1 st. flounder, 1 squawfish \\
\hline 928 & NA & 2 & 1 & 50 & 21.92 & 0.37 & & & 2 & & & & & & \\
\hline 928 & NA & .1 & 1 & 150 & 22.58 & 0.90 & & 1 & & & & 9 & & & \\
\hline 1005 & NA & 3 & 1 & 150 & 20.53 & 0.83 & & & 1 & & & 68 & & 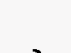 & 1 squawfish \\
\hline 1005 & NA & 1 & 1 & 150 & 21.92 & 0.59 & 1 & & & & & 1 & & & \\
\hline $1005^{\circ}$ & NA & 1 & 1 & 150 & 22.87 & 0.70 & & & 2 & & & 3 & & & \\
\hline 1014 & NA & 2 & 1 & 55 & 13.20 & 0.58 & & & 1 & & - & & & & \\
\hline 1014 & NA & 2 & 1 & 15 & 13.35 & 0.28 & & & & & & & & & \\
\hline 1014 & NA & 3 & 1 & 150 & 14.03 & 0.74 & & & 1 & & & & & & \\
\hline 1014 & NA & 1 & 2 & 150 & 15.25 & 0.77 & & & & & & & & & . \\
\hline 1020 & NA & 1 & 1 & 150 & 22.23 & 0.78 & & & “ & & & 1 & & & \\
\hline 1020 & NA & 1 & 2 & 150 & 23.38 & 0.74 & & & & & & 1 & & & \\
\hline 1020 & NA & 3 & 1 & 150 & 24.73 & 0.74 & & & & 1 & & & & & \\
\hline 1026 & NA & 3 & 2 & 150 & 7.67 & 0.58 & & & & & & & & & \\
\hline 1026 & $N A$ & 2 & 1 & 60 & 8.67 & 0.59 & & & & & & & & & .- \\
\hline 1026 & NA & 1 & 1 & 150 & 9.50 & 0.55 & & & & & & & & & \\
\hline
\end{tabular}

Notes:

Sites $B S=$ Blind Slough

$\mathrm{CC}=$ Cathlamet Channel

$C L=$ Clifton Channel

$D R=$ Deep River/Grays Bay

$S S=$ Steamboat Slough/Skamokawa.

$T P=$ Tongue Point

$W A=$ Wallace Slough

Drifts Numbered as in Figures 1-7

Nets $1=$ Small mesh (5-6")

$2=$ Large mesh (7-8")

Length Length of net in fathoms

Time Hour (and hundredth) that net was set based on 24-hour clock

Hrs Numbers of hours that net was fished, including half of both set and pull time.

Livel

Dead Condition of fish when pullèd from net 


\section{APPENDIX 4. DOCUMENTATION OF ESTIMATES OF SURVIVAL RATES AND DISTRIBUTION IN FISHERIES FOR SELECTED SPECIES AND STOCKS OF COLUMBIA RIVER SALMON CONSIDERED FOR USE IN TERMINAL FISHERIES.}

\section{Source Document}

Annual Coded Wire Tag Program (Oregon) Missing Production Groups, Annual Report. Prepared by Garrison, Isaac, Lewis, Murray. April 1994.

\section{Rogue Fall Chinook}

Survival rate and distribution in fisheries based on 1983-87 brood average for releases at Big Creek Hatchery of $2.51 \%$.

To calculate expected survival advantages for net pen releases, the average survival rates for South Fork Klaskanine Hatchery releases were compared with survival rates for Big Creek Hatchery using 1984 and 1987 broods. The survival advantage factor is 1.77 , expected survival rate for terminal net pen releases is $4.44 \%$.

\section{Early Stock Coho}

Survival rate at ODFW hatcheries (Big Creek, Sandy, Bonneville, and N.F. Klaskanine) averages $3.21 \%$ for $1988-89$ broods.

Estimated survival advantage for net pen releases is based on $1988-89$ brood results for Eagle Creek coho (on station vs. Youngs Bay). A survival advantage of 2.33 is used to calculate an expected survival rate of $7.48 \%$.

Fishery distribution for $1988-89$ brood Eagle Creek stock released from Youngs Bay net pens is used.

\section{Willamette Spring Chinook}

Survival rate for 1984-87 broods at ODFW hatcheries (Marion Forks, McKenzie, South Santiam and Willamette) averages $1.22 \%$, however this value does not include unsampled fisheries above Willamette Falls and naturally spawning populations. A factor of 1.3 was developed based on accountability of the run above Willamette Falls for $1982-87$ broods. The best estimate of survival is $1.59 \%$ using this correction.

Since data is not available for comparison of on-station vs. net pen survival rates for spring chinook, the survival advantage for Rogue stock fall chinook of 1.77. in our opinion could be applied, resulting in an expected survival rate of $2.81 \%$. 
Fishery distribution is calculated using 1984-87 brood data at Marion Forks, McKenzie, South Santiam and Willamette hatcheries.

Bonneville Upriver Brights (URB)

Survival rate is calculated using $1983-87$ brood data for upriver brights released at Bonneville Hatchery averaging $1.93 \%$.

Since URBs have not been released from net pens, the survival advantage for Rogue stock fall chinook of 1.77 is appropriate to use. The expected survival rate is estimated to be $3.42 \%$.

Fishery distribution is calculated using $1983-87$ brood data for URBs released at Bonneville Hatchery. 


\section{APPENDIX 5. TERMINAL FISHERY CAPITALIZATION}

Most of the capitalization would be site specific, but some acquisitions would be for the project as a whole.

Vehicles: Four vehicles, two for each side of the river, would need to be purchased or leased. Half-ton pick-up trucks

$@ \$ 20,000$ each. Lease?

$\$ 80,000$

Misc. Supplies: Dip nets, scales, buckets, thermometers, feed scoops, etc. Estimate $\$ 5,000$ each side of the river.

$\$ 10,000$

Feed Storage: A feed storage trailer for the. Oregon side was included-at the Tongue Point site because of the available space at the site. May need storage space on the Washington side. $40 \mathrm{ft}$ enclosed trailer $\$ 5,000$.

Total

\section{Tongue Point (Oregon)}

Minimal site improvements are needed; basically ready to go. Pens can be secured to existing pier (about 1,000 feet long), and pier to pen access available with additional construction of docks, ramps, etc.

Pens: $\quad 150-200 @ \$ 5,000$ each

$\$ 750,000-1,000,000$

Decks: $\quad 4-5$ decked-over pen frames for storage

(feed, fish handling supplies, nets, etc.)

$\$ 5,400$ each

$\$ 21,600-27,000$

Nets: $\quad 225-300$ confinement nets $(20 \mathrm{ft} \times 20 \mathrm{ft} \times 10 \mathrm{ft}$ deep) Aboùt $\$ 600$ each

$\$ 135,000-180,000$

Feed Storage: $40 \mathrm{ft}$ enclosed trailer @ about $\$ 5,000$ $\$ 5,000$

Hoists: Pen to pier lifting ability. $\$ 2,500$

$\$ 2.500$

Total

$\$ 914,100-1,207,000$

\section{Blind Slough (Oregon)}

To fully utilize the potential at Blind Slough, there will need to be some pilings, floats, access ramps, and docks constructed. The rearing pens will need to be spread out and not connected in one contiguous unit.

Pens: $\quad 30-40 @ \$ 5,000$

$\$ 150,000-200,000$

Decks: $\quad$ One decked-over pen frame for feed, nets,

$\$ 5,400$

Nets: $\quad 45-60$ nets (20ft X 20ft X 10ft deep) @ $\$ 600$ ea.

$\$ 27.000-36,000$ 
Piling: Installation of $10-15$ piling for securing pens/docks. Purchase and installation at about $\$ 850$ each

$\$ 8,500-12,700$

Barge: $\quad$ Motorized platform for feed transfer, net moving, etc., from pen to pen. Motor @ $\$ 3,000$ and barge at about $\$ 5,000$.

\section{Total}

$\$ 8,000$

$\$ 198,000-248,000$

\section{Deep River / Gray's Bay (Washington)}

Access to the useable area would require some piling installation and also an access dock.

Pens: $\quad 40-50 @ \$ 5,000$ each

Decks: One decked-over pen frame for nets, feed, miscellaneous supplies, etc. $\$ 5,400$

Nets: $\quad 60-75 @$ about $\$ 600$ each

Piling: $\quad 20-30$ piling @ $\$ 850$ each installed

Dock: Access/s̀taging dock $\$ 25,000$

Barge: $\quad$ Motorized platform to move.feed, nets, etc. from pen to pen. $\$ 3,000$ motor, $\$ 5,000$ barge.

Total

$\$ 200,000-250,000$

$\$ 5,400$

$\$ 36,000-45,000$

$\$ 17,000-25,000$

$\$ 25,000$

$\$ 8,000$

$\$ 291,400-320,000$

\section{Clifton Channel (Oregon)}

The Clifton fish station and additional potential for piling makes for easy access and area to secure pens.

Pens: $\quad 30-40$ pen frames @ $\$ 5,000$ each

$\$ 150,000-200,000$

One decked-over pen frame for nets, feed, etc., and net cleaning platform. $\$ 5,400$

$\$ 5,400$

Nets: $\quad 45-60$ nets @ about $\$ 600$ each

$\$ 27,000-36,000$

Piling: 5-10 piling installed @ \$850 each $\$ 4,250-8,500$

Barge: Motorized platform for transferring feed, nets, etc. from pen to pen. $\$ 3,000$ motor; $\$ 5,000$ barge.

$\$ 8,000$

Total

$\$ 194,650-244,500$

Steamboat Slough (Washington)

Pens: $\quad 10-20$ pen frames @ $\$ 5,000$ each

Decks: One decked-over pen frame for net cleaning,

$\$ 50,000-100,000$ feed, miscellaneous supplies, etc. $\$ 5,400$

$\$ 5,400$

Nets: $\quad 15-30$ nets @ $\$ 600$ each 
Piling: $\quad 5-10 @ \$ 850$ each installed

Barge: $\quad$ Motorized platform for moving feed, nets, supplies

$\$ 4,250-8,500$

from pen to pen. $\$ 3,000$ motor, $\$ 5,000$ barge

$\$ 8,000$

Total

$\$ 76,000-126,500$

Wallace Slough (Oregon)

The Wallace fish station provides an access point to any associated pens deployed at this location.

Pens: $\quad 20-30$ pen frames @ \$5,000 each $\$ 100,000-150,000$

Deck: - One decked-over pen frame for feed, nets, supplies,

etc. $\$ 5,400$

Nets: $\quad 30-45$ nets @ $\$ 600$ each _ _ _ . . $\quad \$ 18,000-27,000$

Piling: $\quad 10-15$ piling @ $\$ 850$ installed $\quad \$ 8,500-\$ 12,750$

Barge: Motorized work platform for moving feed, nets, supplies, etc. from pen to pen. $\$ 3,000$ motor, $\$ 5,000$ barge.

$\$ 8,000$

Total.

$\$ 139,900-189,750$

Cathlamet Channel (Washington)

Cathlamet Channel has the port of Cathlamet, with associated docks and pilings, on the Washington shoreline.

Pens: $\quad 30-40$ pen frames @ \$5,000 each

$\$ 150,000-200,000$

Deck: One decked-over pen frame for net cleaning, storage, feed, and miscellaneous supplies. $\$ 5,400$

Nets: $\quad 45-60$ nets @ \$600 each

Piling: $\quad 15-20 @ \$ 850$ each installed

Barge: Motorized platform for moving feed, nets, supplies, from pen to pen. $\$ 3,000$ motor, $\$ 5,000$ barge.

$\$ 5,400$

$\$ 27,000-36,000$

$\$ 12,750-17,000$

Total

$\$ 8,000$

$\$ 203,150-253,000$

Youngs Bay (Expansion) .

Access to additional rearing sites is available above and below the existing net pen site and can accommodate a substantial number of pens. Some improvements would be . necessary to utilize the additional areas.

Pens: $\quad$ 60-70 pen frames @ \$5,000 each

Decks: 2-3 decked-over pen frames for net cleaning, feed,

$\$ 300,000-350,000$ storage, nets, etc. $\$ 5,400$ each

Nets: $\quad 90-105$ nets @ $\$ 600$ each

$\$ 10,800-16,200$

Piling: $\quad 30-35$ piling @ $\quad \$ 850$ each installed

$\$ 54,000-63,000$ 
$\$ 25,500-29,750$

Dock: $\quad$ Dock/access gangways $\$ 25,000$

$\$ 25,000$

Barge:

Motorized platform for transferring nets, feed, supplies, etc., from pen to pen.

$\$ 3,000$ motor, $\$ 5,000$ barge.

Total

$\$ 8,000$

$\$ 423,300-458,950$ 


\section{APPENDIX 6. TERMINAL FISHERY OPERATION AND MAINTENANCE}

Project Personnel: The overall project, including all eight sites would employ about 15 salmon culturists, of which two would be working as supervisors: one on each side of the river. The Tongue Point site would have a basic five person crew, two persons working each weekend with a rotating weekend schedule. The Youngs Bay expansion would allow for two additional culturists and they would be incorporated into the existing schedule. Four salmon culturists would be needed to care for the fish and associated activities at the other three sites on the Oregon side (Blind Slough, Clifton Channel, and Wallace Slough):

On the Washington side of the river four culturists would be needed for the fish rearing responsibilities at the three sites (Deep River, Steamboat Slough, and Cathlamet Channel).

Salmon Culturists: 13 FTE @ $\$ 1,600 /$ mo plus benefits @ 40\% (Based on beginning salary level)

Supervisory Culturist: 2 FTE @ $\$ 2,000 / m o$ plus benefits @ 40\% (Based on beginning salary level)

Management/Admin.: 1.5 FTE@ @ 3,000/mo plus benefits @ 40\% $\$ 349,444$ $\$ 67,200$ $\$ 75,600$

Trucking: Fish put in the fish rearing pens will essentially all have to be transferred from some other facility. Trucking expenses are based on conversation with ODFW personnel. A hauling expense of $\$ 0.75 / \mathrm{mile}$ and a round trip of 300 miles has been used for each load of fish. According to ODFW, the existing fleet of trucks could not accommodate the tremendous poundage to be hauled. During April and May when the pounds to be hauled exceeds 1.5 million, additional 30 trucks would be needed, over what could be provided by ODFW. Equipment to accommodate these needs could be purchased for about $\$ 1$ million.

Leases: At each site there is a requirement to secure a submerged land lease, and in Oregon the lease fee is determined by the upland property value. Six percent of the upland value is applied to the area utilized by rearing pens. Most all the potential rearing sites are in areas that have a similar upland value as in Blind Slough. The recent submerged land lease was based on an upland value of about $\$ 0.90 /$ sq.ft. For a single net pen unit, the submerged land lease would be about $\$ 31 /$ pen. This fee will be applied at each site for the anticipated number of pens; however, understanding that property values may vary from site to site.

Also, upland property owners may request a fee/lease or some sort of monetary agreement to use the property. At existing sites in Youngs Bay and Blind Slough, this fee has ranged from $\$ 100$ to $\$ 200$ per pen moorage fee/year plus a fee to the upland property. Upland property use may range from simply providing parking to more 
extensive use like electrical, water, storage, etc. Upland property use may require a fee ranging from $\$ 1,00$ to $\$ 5,000 /$ year.

Permits: Permit fee may be required at each site. Land use permits are issued by the Oregon Department of Environmental Quality and Washington Department of Ecology.

Replacement Supplies: The walkways on the net pen frames are simple $2 \times 12$ lumber planks bolted to the frame. Life expectancy of this lumber has not been determined, but replacement cost for lumber for each pen would be about $\$ 200$. A 7-10 year life may be expected. The confinement nets hung from the pen frames have an estimated life expectancy of 5 years. So, each year; $20 \%$ of the total number of nets used would be replaced. Each net costs about $\$ 600$. Replacement of $20 \%$ of the nets used at each site has been determined with the associated expense.

\section{Tongue Point (Oregon)}

Feed: Spring Chinook

Spring Chinook

Coho

Coho

Coho

Fall Chinook
3-4 million, November to February $30 / \mathrm{lb}$ to $10 / \mathrm{lb}, 240,000-266,700 \mathrm{lbs}$ food needed @ \$0.50/lb 3-4 million, March rearing 12/lb-10/lb, 60,000-80,000 lbs food needed @ \$0.50/lb 3-4. million, April 1-15 acclimation feed $1 \%$ body weight/day for 14 days @ 12/lb. 35,000-46,700 lbs food.needed @ \$0.50/lb

3-4 million, April 15-30 acclimation same as above

3-4 million, May 1-15 acclimation same as above 3-4 million, May 15-30 acclimation same as above

4.5-6 million, June-August $60 / \mathrm{lb}$ to $15 / \mathrm{lb}, 270,000-360,000 \mathrm{lbs}$ food needed @ \$0.50/lb
$\$ 120.000-133,350$

$\$ 30,000-40,000$

$\$ 17,500-23,350$

$\$ 17,500-23,350$

$\$ 17,500-23,350$

$\$ 17,500-23,350$

$\$ 135,000-180,000$

Coded-wire tagging:

Spring Chinook

Spring Chinook

3-4 million, Nov. to Feb.

CWT.50,000@@105/1,000

$\$ 5,250$

3-4 million, March

CWT 50,000@ @ \$105/1,000

$\$ 5,250$

Coho

3-4 million, April 1-15 acclimation 
CWT 25,000 @ $\$ 105 / 1,000$ CWT 25,000 and $100 \%$ fin-clip

Coho

Coho

Coho

Fall Chinook
3-4 million, April 15-30 acclimation

CWT 25,000 @ \$105/1,000

CWT 25,000 and $100 \%$ fin-clip

3-4 million, May 1-15 acclimation

CWT 25,000 @ \$105/1,000

CWT 25,000 and $100 \%$ fin-clip

3-4 million, May 15-30 acclimation

CWT 25,000 @ \$105/1,000.

CWT 25,000 and $100 \%$ fin-clip

4.5-6 million, June-August

CWT 50,000 @ \$105/1,000

CWT 50,000 and $100 \%$ fin-clip
$\$ 2,625$

$\$ 77,000-102,000$

$\$ 2,625$

$\$ 77,000-102,000$

$\$ 2,625$

$\$ 77,000-102,000$

$\$ 2,625$

$\$ 77,000-102,000$

$\$ 5,250$

$\$ 116,500-154,000$

Trucking:

Spring Chinook . 3-4 million November @ 30/lb

40-53 loads

$\$ 9,000-11,925$

Spring Chinook 3-4 million March @ 12/lb

100-133 loads

$\$ 22,500-29,925$

Coho

3-4 million April 1 @ 12/lb 100-133 loads

$\$ 22,500-29,925$

Coho · 3-4 million April 15 @ 12/lb 100-133 loads

Coho

3-4 million May 1 @ 12/lb

100-133 loads

Coho

3-4 million May 15 @ 12/lb $100-133$ loads

Fall Chinook

4.5-6 million June @ 60//b

$30-40$ loads

$\$ 22,500-29,925$

$\$ 22,500-29,925$

$\$ 22,500-29,925$

$\$ 6,750-9,000$

Leases: Submerged land lease @ \$31/pen/year

$\$ 4,650-6,200$

Upland property use fee

$\$ 1,000-5,000$

Permits: $\quad$ ODEQ General Waste Discharge Permit (300 J)

$\$ 600$

Replacement Nets: $\quad 30-40 @ \$ 600$ each

$\$ 18,000-24,000$

(Beginning 2nd year) 


\section{Blind Slough (Oregon)}

Feed: Spring Chinook

Spring Chinook

Coho

Coho

Coho

Coho

Fall Chinook
$600,000-800,000$, Nov. to Feb.

$30 / \mathrm{lb}$ to $10 / \mathrm{lb}, 48,000-64,000 \mathrm{lbs}$ food needed @ \$0.50/lb $600,000-800,000$, March rearing $12 / \mathrm{lb}$ to $10 / \mathrm{lb}, 12,000-16,000 \mathrm{lbs}$ food needed @ \$0.50/lb $600,000-800,000$, April 1-15 acclimation feed $1 \%$ body weight/day for 14 days @ 12/lb. 7,000-9,333 lbs food needed @ \$0.5./lb

$600,000-800,000$, April 15-30 acclimation same as above $600,000-800,000$, May 1-15 acclimation same as above $600,000-800,000$, May 15-30 acclimation same as above 900,000-1.2 million, June-August food needed @ \$0.50/lb.

$\$ 27,000-36,000$

$\$ 24,000-32,000$

$\$ 6,000-8,000$

$\$ 3,500-4,667$

$\$ 3,500-4,667$

$\$ 3,500-4,667$

$\$ 3,500-4,667$

$60 / \mathrm{lb}$ to $15 / \mathrm{lb}, 54,000-72,000 \mathrm{lbs}$

$$
\text { food needed@ \$0.50lb. }
$$

Coded-wire tagging:

Spring Chinook

Spring Chinook

Coho

$600,000-800,000$, Nov. to Feb.

CWT 50,000@ @ $\$ 105 / 1,000$

$\$ 5,250$

$600,000-800,000$, March rearing

CWT 50,000 @ \$105/1,000.

$\$ 5,250$

$600,000-800,000$, April 1-15 acclimation

CWT 25,000 @ \$105/1,000

CWT 25,000 and $100 \%$ fin-clip

Coho : $\quad 600,000-800,000$, April 15-30 acclimation

CWT 25,000@ @ $\$ 105 / 1,000$

CWT 25,000 and $100 \%$ fin-clip

Coho : $600,000-800,000$, May $1-15$ acclimation

CWT 25,000@ @105/1,000

CWT 25,000 and $100 \%$ fin-clip

Coho

$600,000-800,000$, May 15-30 acclimation

CWT 25,000@ @ $\$ 105 / 1,000$

CWT 25,000 and $100 \%$ fin-clip

Fall Chinook

Trucking:

CWT 50,000 @ \$105/1,000

CWT 50,000 and $100 \%$ fin-clip
$\$ 2,625$

$\$ 17,000-22,000$

$\$ 2,625$

$\$ 17,000-22,000$

$\$ 2,625$

$\$ 17,000-22,000$

$\$ 2,625$

$\$ 17,000-22,000$

$\$ 5,250$

$\$ 26,500-34,000$ 
Spring Chinook 600,000-800,000, Nov. @ 30/lb

8-11 loads

$\$ 1,800-2,475$

Spring Chinook 600,000-800,000, March @ 12/lb

20-27 loads

Coho

600,000-800,000; April 1 @ 12/lb

20-27 loads

$\$ 4,500-6,075$

$\$ 4,500-6,075$

Coho

$600,000-800,000$, April 15 @ 12/lb

20-27 loads

$\$ 4,500-6,075$

Coho

$600,000-800,000$, May $1 @ 12 / \mathrm{lb}$

20-27 loads

Coho

$600,000-800,000$, May 15 @ 12/lb

20-27 loads

Fall Chinook 900,000-1.2 million, June @ 60/lb

6-8 loads

$\$ 4,500-6,075$

$\$ 4,500-6,075$

$\$ 1,350-1,800$

$\$ 930-1,240$

$\$ 1,000-5,000$

Upland property use fee

$\$ 600$

Permits: $\quad$ ODEQ General Waste Discharge Permit (300 J)

$\$ 600$

Replacement Nets: $\quad 6-8 @ \$ 600$ each

$\$ 3,600-4,800$

(Beginning 2nd Year)

\section{Deep River / Grays Bay (Washington)}

Feed: Spring Chinook $\quad 800,000-1$ million, Nov. to Feb.

$30 / \mathrm{lb}$ to $10 / \mathrm{lb}, 64,000-80,000 \mathrm{lbs}$

food needed @ \$0.50/lb.

$\$ 32,000-40,000$

Spring Chinook $800,000-1$ million, Nov. to Feb.

$12 / \mathrm{lb}$ to $10 / \mathrm{lb}, 16,000-20,000 \mathrm{lbs}$ food needed @ \$0.50/lb.

Coho : $800,000-1$ million, April 1-15 acclimation feed $1 \%$ body weight/day for 14 days

@ 12/ib. 9,333-11,667 lbs food needed @ $\$ 0.50 / \mathrm{lb}$.

Cóno 800,000-1 million, April 15-30 acclimation same as above

Coho . 800,000-1 million, May 1-15 acclimation same as above

Coho 800,000-1 million, May 15-30 acclimation same as above

$\$ 8,000-10,000$

$\$ 4,667-5,834$

$\$ 4,667-5,834$

$\$ 4,667-5,834$

$\$ 4,667-5,834$ 
Fall Chinook

1.2-1.5 million, June-August

$60 / \mathrm{lb}$ to $15 / \mathrm{lb}, 72,000-90,000 \mathrm{lbs}$

food needed @ \$0.50/lb

$\$ 36,000-45,000$

Coded-wire tagging:

Spring Chinook

800,000-1 million. Nov. to Feb.

CWT 50,000@ \$105/1,000

$\$ 5,250$

Spring Chinook

800,000-1 million, March rearing

CWT 50,000@ @ \$105/1,000

$\$ 5,250$

Coho

$800,000-1$ million, April 1-15 acclimation

CWT 25,000 @ \$105/1,000

$\$ 2,625$

CWT 25,000 and $100 \%$ fin-clip

Coho

800,000-1 million, April 15-30 acclimation

CWT 25,000@ @ $\$ 105 / 1,000$

CWT 25,000 and $100 \%$ fin-clip

Coho.

800,000-1 million, May 1-15 acclimation

CWT 25,000 @ \$105/1,000

CWT 25,000 and $100 \%$ fin-clip

Coho

$800,000-1$ million, May 15-30 acclimation

CWT 25,000 @ \$105/1,000

CWT 25,000 and $100 \%$ fin-clip

Fall Chinook

1.2-1.5 million, June to August

CWT 50,000 @ \$105/1,000

CWT 50,000 and $100 \%$ fin-clip

$\$ 22,000-27,000$

$\$ 2,625$

$\$ 22,000-27,000$

$\$ 2,625$

$\$ 22,000-27,000$

$\$ 2,625$

$\$ 22,000-27,000$

$\$ 5,250$

$\$ 34,000-41,500$

Trucking:

Spring Chinook 800,000-1 million, Nov @ 30/lb 11-14 loads

$\$ 2,475-3,150$

Spring Chinook

800,000-1 million, March @ 12/lb

27-34 loads

$\$ 6,075-7,650$

Coho

800,000-1 million, April $1 @$ 12/lb

27-34 loads

$\$ 6,075-7,650$

Coho

800,000-1 million, April $15 @ 12 / \mathrm{lb}$

27-34 loads

$\$ 6,075-7,650$

Coho

800,000-1 million, May $1 @ 12 / \mathrm{lb}$

27-34 loads

Coho

'800,000-1 million, May 15 @ 12/lb 27-34 loads

$\$ 6,075-7,650$

Fall Chinook 1.2-1.5 million, June @ 60/lb

8-10 loads

$\$ 6,075-7,650$

$\$ 1,800-2,250$

$\$ 1,200-1,550$

Leases: Submerged land lease @ \$31/pen/year 
Permits: $\quad$ ODEQ General Waste Discharge Permit

$\$ 600$

Replacement Nets:

8-10@\$600 each

$\$ 4,800-6,000$

(Beginning 2nd Year)

\section{Clifton Channel (Oregon)}

Feed: Spring Chinook $\quad 600,000-800,000$, Nov. to Feb.

$30 / \mathrm{lb}$ to $10 / \mathrm{lb}, 48,000-64,000 \mathrm{lbs}$

food needed @ \$0.50/lb

$\$ 24,000-32,000$

Spring Chinook $600,000-800,000$, March rearing $12 / \mathrm{lb}$ to $10 / \mathrm{lb}, 12,000-16,000 \mathrm{lbs}$ food needed @ \$0.50/lb

Coho $600,000-800,000$, April 1-15 acclimation feed $1 \%$ body weight/day for 14 days @ 12/lb. 7,000-9,333 lbs food needed@\$0.50/b

Coho $600,000-800,000$, April 15-30 acclimation same as above.

Coho $600,000-800,000$, May 1-15 acclimation same as above.

Coho $600,000-800,000$, May 15-30 acclimation same as above.

Fall Chinook $\quad 900,000-1.2$ million, June-August $60 / \mathrm{lb}$ to $15 / \mathrm{lb}, 54,000-72,000 \mathrm{lbs}$ food needed @ \$0.50/lb.

$\$ 27,000-36,000$

Coded-Wire tagging: Spring Chinook

Spring Chinook

$600,000-800,000$, Nov. to Feb.

CWT 50,000 @ \$105/1,000

$\$ 5,250$ $600,000-800,000$, March rearing CWT 50,000 @ \$105/1,000

Coho $600,000-800,000$, April 1-15 acclimation CWT 25,000 @ \$105/1,000 CWT 25,000 and $100 \%$ fin-clip

Coho $600,000-800,000$, April 15-30 acclimation CWT 25,000 @ $\$ 105 / 1,000$ CWT 25,000 and $100 \%$ fin-clip

Coho $600,000-800,000$, May 1-15 acclimation $\$ 3,500-4,667$ $\$ 3,500-4,667$ $\$ 3,500-4,667$ $\$ 3,500-4,667$ CWT 25,000@\$105/1,000 $\$ 5,250$ $\$ 2,625$ $\$ 17,000-22,000$ $\$ 2,625$ $\$ 17,000-22,000$ $\$ 2,625$ 
Coho

CWT 25,000 and $100 \%$ fin-clip $600,000-800,000$, May 15-30 acclimation

CWT 25,000 @ \$105/1,000

CWT 25,000 and $100 \%$ fin-clip

Fall Chinook
$\$ 17,000-22,000$

$\$ 2,625$

$\$ 17,000-22,000$

$\$ 5,250$

$\$ 26,500-34,000$

Trucking:

Spring Chinook .600,000-800,000, Nov. @ 30/lb 8-11 loads

Spring Chinook 600,000-800,000, March @ 12/lb 20-27 loads

Coho $600,000-800,000$, April $1 @ 12 / \mathrm{lb}$ 20-27 loads

Coho . $\quad 600,000-800,000$, April $15 @ 12 / 1 \mathrm{~b}$

Coho 20-27 loads $600,000-800,000$, May 1-@12/lb 20-27 loads

Coho $600,000-800,000$, May $15 @ 12 / \mathrm{lb}$ 20-27 loads

Fall Chinook 900,000-1.2 million, June @ 60/lb 6-8 loads

Leases: Submerged land lease @ \$31/pen/year

$\$ 1,800-2,475$

$\$ 4,500-6,075$

$\$ 4,500-6,075$

$\$ 4,500-6,075$

$\$ 4,500-6,075$

$\$ 4,500-6,075$

$\$ 1,350-1,800$

$\$ 930-1,240$

$\$ 1,000-5,000$

Upland property use fee

$\$ 600$

Permits: ODEQ General Waste Discharge Permit (300 J)

Replacement Nets:

6-8@\$600 each

$\$ 3,600-4,800$

(Beginning 2nd Year)

\section{Steamboat Slough (Washington)}

Feed: Spring Chinook

Spring Chinook

Coho
$200,000-400,000$, Nov. to Feb.

$30 / \mathrm{lb}$ to $10 / \mathrm{lb}, 16,000-32,000 \mathrm{lbs}$

food needed @ \$0.50/lb

$200,000-400,000$, March rearing

$12 / \mathrm{lb}$ to $10 / \mathrm{lb}, 4,000-8,000 \mathrm{lbs}$

food needed @ \$0.50/lb

200,000-400,000, April 1-15 acclimation

feed $1 \%$ body weight/day for 14 days
$\$ 8,000-16,000$

$\$ 2,000-4,000$ 
Coho

Coho

Coho

Fall Chinook
@ 12/lb. 2,333-4,666 lbs food needed @ \$0.50/lb 200,000-400,000, April 15-30 acclimation same as above $200,000-400,000$, May 1-15 acclimation same as above 200,000-400,000; May 15-30 acclimation same as above $300,000-600,000$, June-August $60 / \mathrm{lb}$ to $15 / \mathrm{lb}, 18,000-36,000 \mathrm{lbs}$ food needed @ \$0.50/lb.
$\$ 1,167-2,333$

$\$ 1,167-2,333$

$\$ 1,167-2,333$

$\$ 1,167-2,333$

$\$ 9,000-18,000$

Coded-wire tagging:

Spring Chinook

Spring Chinook

Coho

Coho

Coho

Coho

Fall Chinook
$200,000-400,000$, November-February

CWT 50,000 @ $\$ 105 / 1,000$

200,000-400,000, March rearing

CWT 50,000 @ \$105/1,000

200,000-400,000, April 1-15 acclimation

CWT 25,000 @ 105/1,000

CWT 25,000 and $100 \%$ fin-clip

200,000-400,000, April 15-30 acclimation

CWT 25,000 @ 105/1,000

CWT 25,000 and $100 \%$ fin-clip

200,000-400,000, May 1-15 acclimation

CWT 25,000 @ 105/1,000

CWT 25,000 and $100 \%$ fin-clip

200,000-400,000, May 15-30 acclimation

CWT 25,000 @ 105/1,000

CWT 25,000 and $100 \%$ fin-clip

$300,000-600,000$, June to August

CWT 50,000 @ \$105/1,000

CWT 50,000 and $100 \%$ fin-clip
$\$ 5,250$

$\$ 5,250$

$\$ 2,625$

$\$ 7,000-12,000$

$\$ 2,625$

$\$ 7,000-12,000$

$\$ 2,625$

$\$ 7,000-12,000$

$\$ 2,625$

$\$ 7,000-12,000$

$\$ 5,250$

$\$ 11,500-19,000$

$\$ 675-1,350$

$\$ 1,575-3,150$

$\$ 1,575-3,150$

$\$ 1,575-3,150$

Coho

200,000-400,000, Nov. @ 30/lb

3-6 loads

200,000-400,000, March @ 12/lb .

7-14 loads

200,000-400,000, April $1 @$ 12/lb

7-14 loads

200,000-400,000, April 15 @ 12/lb

7-14 loads

200,000-400,000, May, 1 @ 12/lb 
Coho 200,000-400,000, May 15 @ 12/lb

7-14 loads

$\$ 1,575-3,150$

Fall Chinook 300,000-600,000, June @ 60/lb 2-4 loads

Leases: Submerged land lease @ \$31/pen/year.

$\$ 310-620$

Upland property use fee

$\$ 1,000-5,000$

Permits: $\quad$ ODEQ General Waste Discharge Permit (300 J)

$\$ 600$

Replacement Nets:

2-4@\$600 each

$\$ 1,200-2,400$

(Beginning 2nd Year)

\section{Wallace Slough (Oregon)}

Feed: Spring Chinook $\quad 400,000-600,000$, Nov. to Feb. $30 / \mathrm{lb}$ to $10 / \mathrm{lb}, 32,000-48,000 \mathrm{lbs}$ food needed @ \$0.50/lb.

$\$ 16,000-24,000$

Spring Chinook 400,000-600,000, March rearing $12 / \mathrm{lb}$ to $10 / \mathrm{lb}, 8,000-12,000 \mathrm{lbs}$ food needed@ @ \$0.50/lb.

Coho 400,000-600,000, April 1-15 acclimation $\$ 4,000-6,000$ feed $1 \%$ body weight/day for 14 days

@ 12.lb, 4,667-7,000 lbs food needed @ \$0.50/lb.

$\$ 2,334-3,500$

Coho 400,000-600,000, April 15-30 acclimation same as above $\$ 2,334-3,500$

Coho $400,000-600,000$, May 1-15 acclimation same as above $\$ 2,334-3,500$

Coho

- 400,000-600,000, May 15-30 acclimation same as above $\$ 2,334-3,500$

Fall Chinook $600,000-900,000$, June-August $60 / \mathrm{lb}$ to $15 / \mathrm{lb}, 36,000-54,000 \mathrm{lbs}$ food needed @ \$0.50/lb.

Coded-wire tagging:

Spring Chinook $400,000-600,000$, November to February CWT 50,000@ @ $105 / 1,000$ $\$ 5,250$ Spring Chinook 400,000-600,000, March rearing CWT 50,000@ @ $105 / 1,000$ 
Coho 400,000-600,000, April 1-15 acclimation

CWT 25,000 @ \$105/1,000

CWT 25,000 and $100 \%$ fin-clip

Coho

400,000-600,000, April 15-30 acclimation

CWT 25,000@ @ $\$ 105 / 1,000$

CWT 25,000 and $100 \%$ fin-clip

Coho

400,000-600,000, May 1-15 acclimation

CWT 25,000 @ \$105/1,000

CWT 25,000 and $100 \%$ fin-clip

Coho

$400,000-600,000$, May 15-30 acclimation

CWT 25,000@ \$105/1,000

CWT 25,000 and $100 \%$ fin-clip

Fall Chinook

$600,000-900,000$; June to August

CWT 50,000 @ \$105/1,000

CWT 50,000 and $100 \%$ fin clip

$\$ 2,625$

$\$ 12,000-17,000$

$\$ 2,625$

$\$ 12,000-17,000$

$\$ 2,625$

$\$ 12,000-17,000$

$\$ 2,625$

$\$ 12,000-17,000$

$\$ 5,250$

$\$ 19,000-26,500$

Trucking:

Spring Chinook 400,000-600,000, November @ 30/lb

6-8 loads

$\$ 1,350-1,800$

Spring Chinook 400,000-600,000, March @ 12/lb

14-20 loads

Coho

400,000-600,000, April $1 @ 12 / \mathrm{lb}$

Coho

14-20 loads

400,000-600,000, April 15 @ 12/lb

14-20 loads

Coho

400,000-600,000, May $1 @ 12 / \mathrm{lb}$

Coho

14-20 loads

400,000-600,000, May 15 @ 12//b

14-20 loads

$\$ 3,150-4,500$

$\$ 3,150-4,500$

$\$ 3,150-4,500$

$\$ 3,150-4,500$

600,000-900,000, June @ 60/lb

4-6 loads

$\$ 3,150-4,500$

$\$ 900-1,350$

Leases: Submerged land lease @ \$31/pen/year

$\$ 620-930$

Upland property use fee.

$\$ 1,000-5,000$

Permits: $\quad$ ODEQ General Waste-Discharge Permit (300 J)

$\$ 600$

Replacement Nets: $\quad$ 4-6 @ \$600 each

(Beginning 2nd Year)

$\$ 2,400-3,600$ 


\section{Cathlamet Channel (Washington)}

Feed: Spring Chinook $\quad 600,000-800,000$, Nov. to Feb.

$30 / \mathrm{lb}$ to $10 / \mathrm{lb}, 48,000-64,000 \mathrm{lbs}$

food needed @ \$0.50/lb.

$\$ 24,000-32,000$

Spring Chinook

$600,000-300,000$, March rearing

$12 / \mathrm{lb}$ to $10 / \mathrm{lb}, 12,000-16,000 \mathrm{lbs}$

food needed @ \$0.50/lb:

$\$ 6,000-8,000$

Coho $600,000-800,000$, April 1-15 acclimation feed $1 \%$ body weight/day for 14 days @ 12/lb. 7,000-9,333 lbs food needed@ @0.50/lb.

Coho $\quad 600,000-800,000$, April 15-30 acclimation same as above

Coho $600,000-800,000$, May 1-15 acclimation same as above

Coho $600,000-800,000$, May $15-30$ acclimation same as above $\$ 3,500-4,667$

$\$ 3,500-4,667$

$\$ 3,500-4,667$

$\$ 3,500-4,667$

Fall Chinook

$900,000-1.2$ million, June-August $60 / \mathrm{lb}$ to $15 / \mathrm{lb}, 54,000-72,000 \mathrm{lbs}$ food needed @ \$0.50/lb.

$\$ 27,000-36,000$

Coded-wire tagging:

Spring Chinook

Spring Chinook

$600,000-800,000$, November to February CWT 50,000@ @ $\$ 105 / 1,000$

$\$ 5,250$ $600,000-800,000$, March rearing CWT 50,000@ @ 105/1,000

$\$ 5,250$

Coho $600,000-800,000$, April 1-15 acclimation CWT 25,000@ @ \$105/1,000

$\$ 2,625$ CWT 25,000 and $100 \%$ fin-clip

Coho $600,000-800,000$, April 15-30 acclimation CWT 25,000 @ \$105/1,000 CWT 25,000 and $100 \%$ fin-clip

Coho $600,000-800,000$, May 1-15 acclimation CWT 25,000 @ \$105/1,000 CWT 25,000 and $100 \%$ fin-clip

Coho $600,000-800,000$, May 15-30 acclimation CWT 25,000@ @ \$105/1,000 CWT 25,000 and $100 \%$ fin-clip Fall Chinook 900,000-1.2 million, June to August

CWT 50,000@\$105/1,000 CWT 50,000 and $100 \%$ fin-clip 
Trucking:

Spring Chinook $\quad 600,000-800,000$, November @ 30/lb

8-11 loads

Spring Chinook 600,000-800,000, March @ 12/lb

20-27 loads

Coho

600,000-800,000, April 1 @ 12/lb

20-27 loads

Coho

$600,000-800,000$, April $15 @ 12 / \mathrm{lb}$

20-27 loads

Coho

$600,000-800,000$, May $1 @ 12 / \mathrm{lb}$

20-27 loads

Coho

$600,000-800,000$, May $15 @ 12 / / \mathrm{b}$

Fall Chinook

20-27 loads

900,000-1.2 million, June @ 60/lb

6-8 loads

$\$ 1,800-2,475$

$\$ 4,500-6,075$

$\$ 4,500-6,075$

$\$ 4,500-6,075$

$\$ 4,500-6,075$

$\$ 4,500-6,075$

$\$ 1,350-1,800$

$\$ 930-1,240$

Leases: Submerged land lease @ \$31/pen/year

$\$ 1,000-5,000$

Upland property use fee

$\$ 600$

Permits: ODEQ General Waste Discharge Permit (300 J)

Replacement Nets:

6-8@\$600 each .

(Beginning 2nd Year)

$\$ 3,600-4,800$

\section{Youngs Bay (Expansion)}

Feed: Spring Chinook

Spring Chinook

Coho

Coho

Coho

Coho
1.4-1.7 million, Nov. to Feb.

$30 / \mathrm{lb}$ to $10 / \mathrm{lb}, 112,000-136,000 \mathrm{lbs}$ food needed @ \$0.50/lb.

1.4-1.7 million, March rearing

$12 / \mathrm{lb}$ to $10 / \mathrm{lb}, 28,000-34,000 \mathrm{lbs}$ food needed @ \$0.50/lb

1.4-1.7 million, April 1-15 acclimation

feed at $1 \%$ body weight/day for 14 days

@ 12/lb. 16,333-19,833 lbs food needed @ \$0.50/lb.

1.4-1.7 million, April 15-30 acclimation same as above

1.4-1.7 million, May 1=15 acclimation

same as above

1.4-1.7 million, May 15-30 acclimation
$\$ 56,000-68,000$

$\$ 14,000-17,000$

$\$ 8,167-9,917$

$\$ 8,167-9,917$

$\$ 8,167-9,917$ 
Fall Chinook

above

2.1-2.5 million, June-August

$60 / \mathrm{lb}$ to $15 / \mathrm{lb}, 126,000-150,000 \mathrm{lbs}$

food needed @ \$0.50/lb.
$\$ 8,167-9,917$

$\$ 63,000-75,000$
Coded-wire tagging:

Spring Chinook

Spring Chinook

-

Coho

Coho

Coho

Coho

Fall Chinook
1.4-1.7 million, November to February

CWT 50,000@ @ $\$ 105 / 1,000$

1.4-1.7 million, March rearing

CWT 50,000@ \$105/1,000

1.4-1.7 million, April 1-15 acclimation

CWT 25,000@ @ \$105/1,000

CWT 25,000 and $100 \%$ fin-clip

1.4-1.7 million, April 15-30 acclimation

CWT 25,000 @ \$105/1,000

CWT 25,000 and $100 \%$ fin-clip

1.4-1.7 million, May 1-15 acclimation

CWT 25,000@ @ $\$ 105 / 1,000$

CWT 25,000 and $100 \%$ fin-clip

1.4-1.7 million, May 15-30 acclimation

CWT 25,000@ \$105/1,000

CWT 25,000 and $100 \%$ fin-clip

2.1-2.5 million, June to August

CWT 50,000@ @ \$105/1,000

CWT 50,000 and $100 \%$ fin-clip
$\$ 5,250$

$\$ 5,250$

$\$ 2 ; 625$

$\$ 37,000-44,500$

$\$ 2,625$

$\$ 37,000-44,500$

$\$ 2,625$

$\$ 37,000-44,500$

$\$ 2,625$

$\$ 37,000-44,500$

$\$ 5,250$

$\$ 56,500-66,500$

Trucking:

Spring Chinook

1.4-1.7 million, November @ 30/lb 19-23 loads

Spring Chinook 1.4-1.7 million, March @ 12/lb 47-57 loads

Coho - 1.4-1.7 million, April 1 @ 12/lb 47-57 loads

Coho

1.4-1.7 million, April 15 @ 12/lb

47-57 loads

Coho

1.4-1.7 million, May $1 @ 12 / \mathrm{lb}$

47-57 loads

Coho

1.4-1.7 million, May $15 @ 12 / \mathrm{lb}$

47-57 loads

Fall Chinook

2.1-2.5 million, June @.60/lb

14-17 loads
$\$ 4,275-5,175$

$\$ 10,575-12,825$

$\$ 10,575-12,825$

$\$ 10,575-12,825$

$\$ 10,575-12,825$

$\$ 10,575-12,825$

$\$ 3,150-3,825$

$\$ 1,860-2,170$

Leases: · Submerged land lease @ \$31/pen/year 
Permits: $\quad$ ODEQ General Waste Discharge Permit (300 J) 


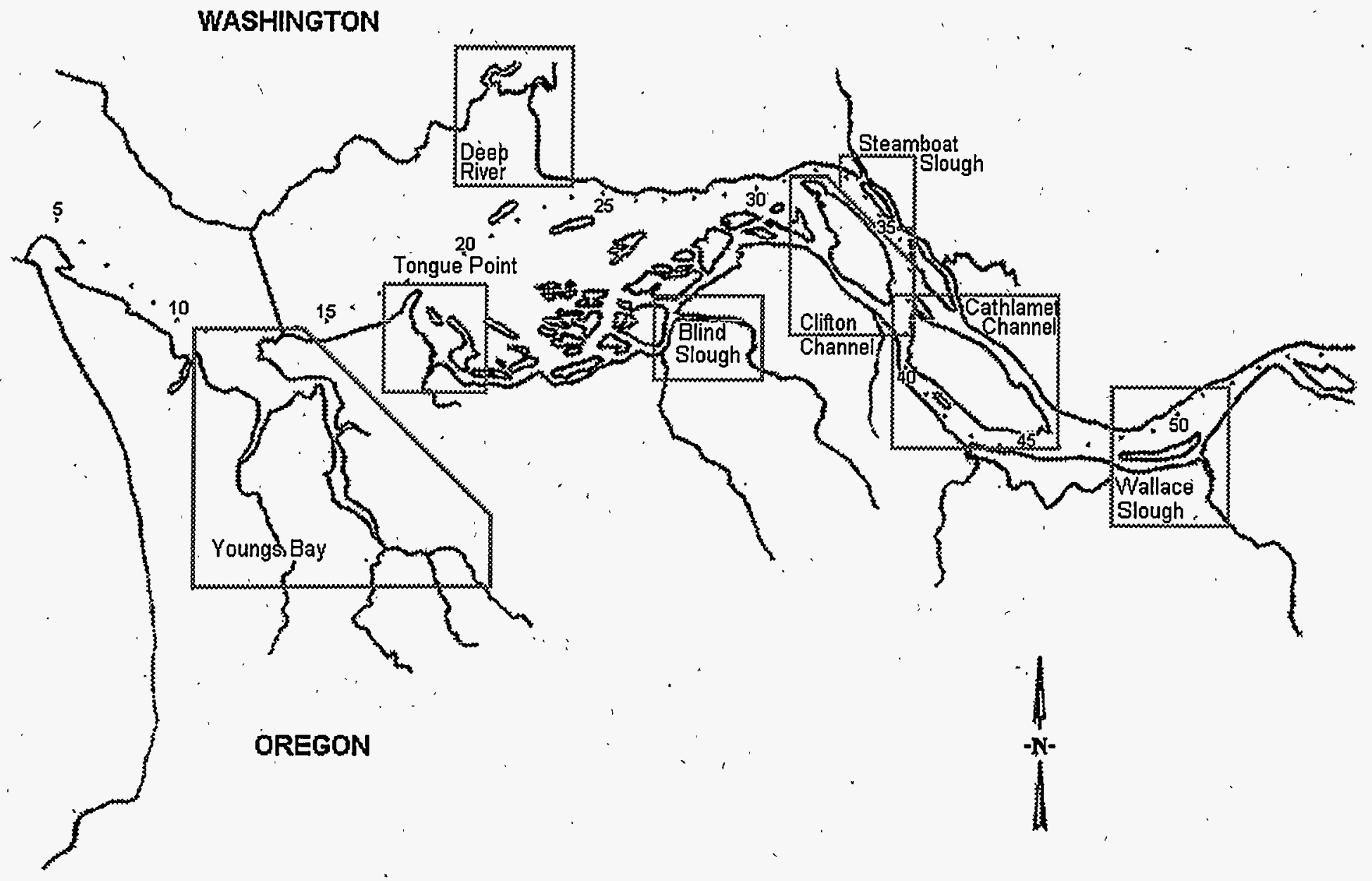

Figure 1. Lower Columbia River terminal fishery sites. 


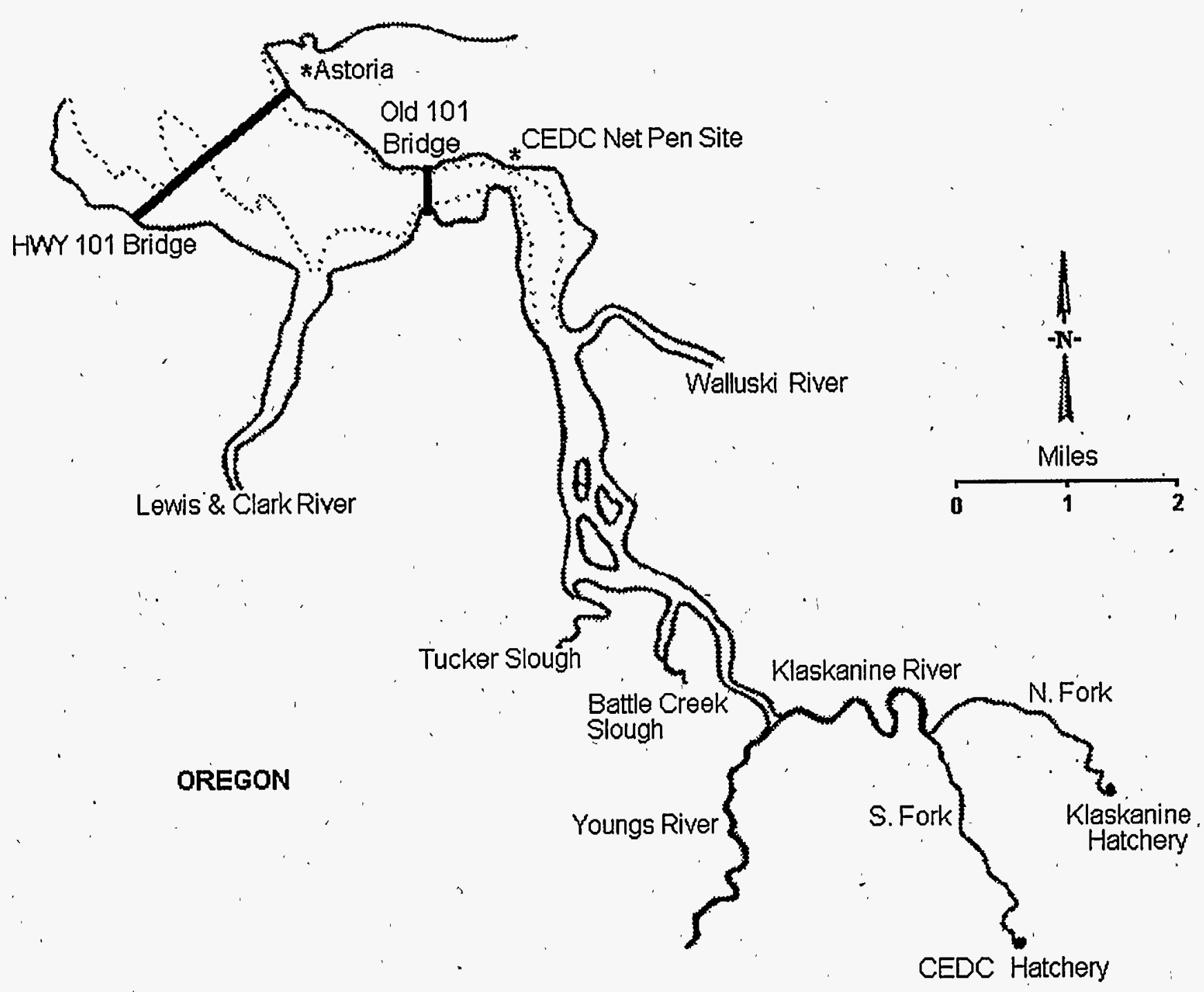

Figure 2. Young Bay terminal fishery area. 


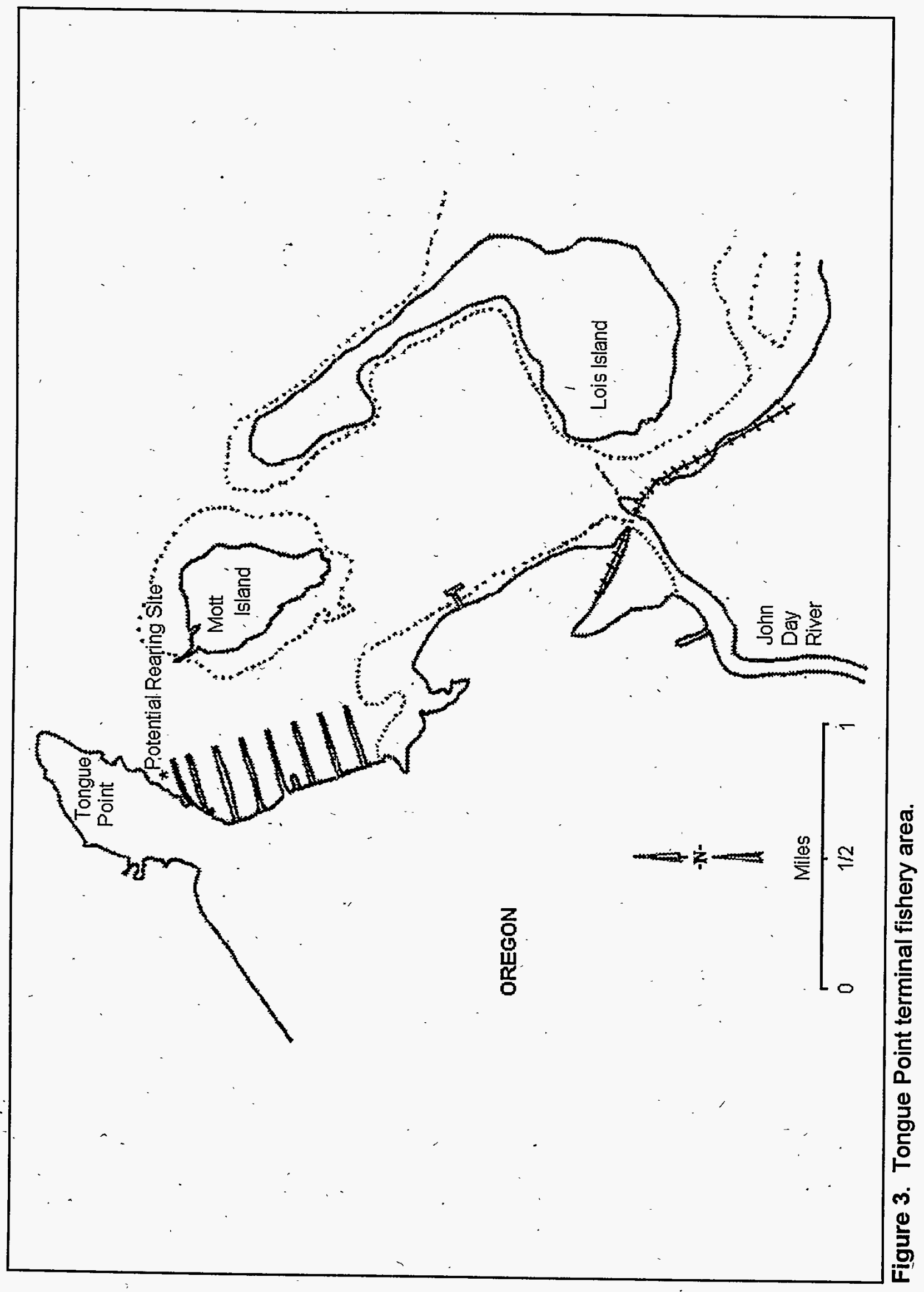




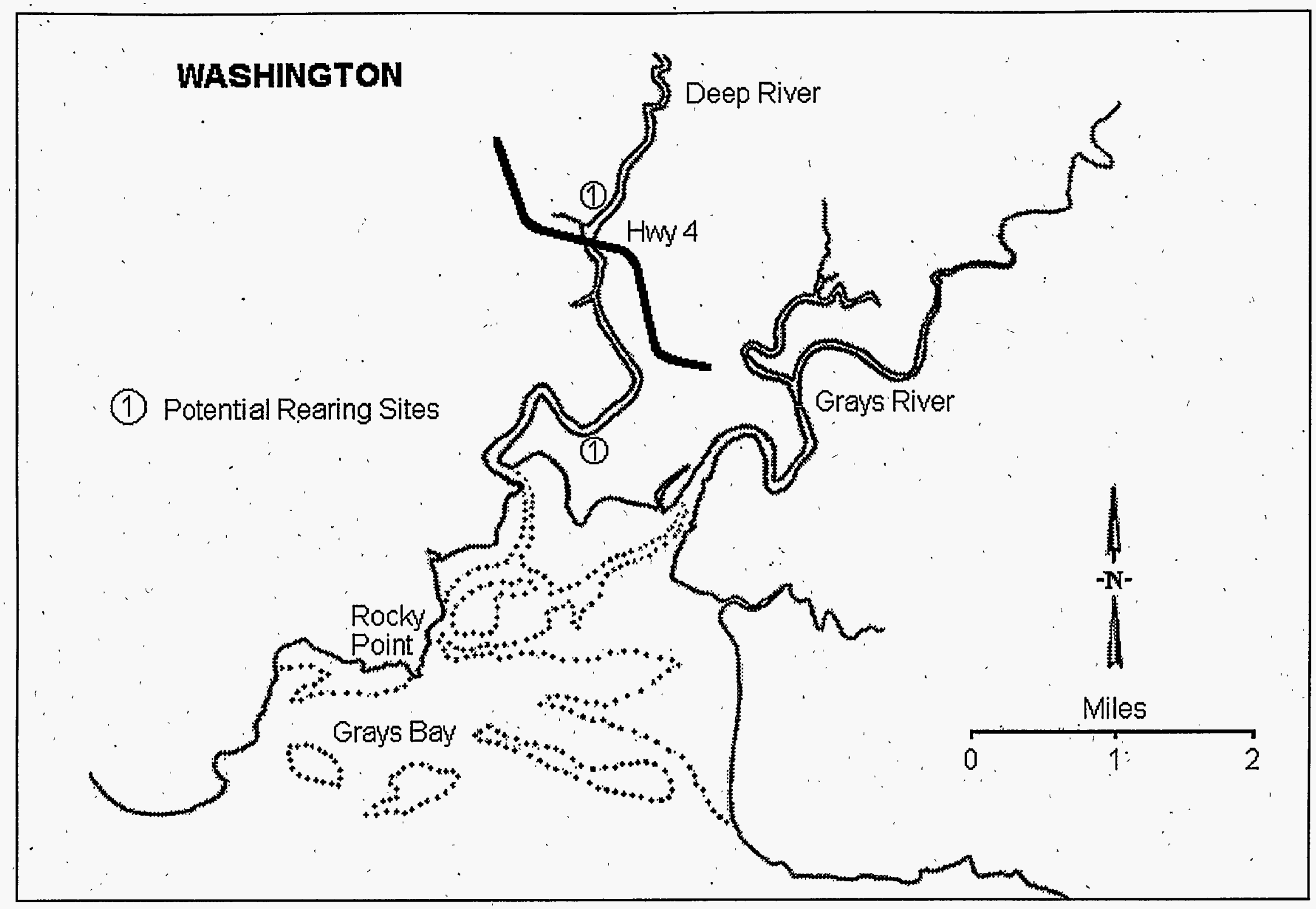

Figure 4. Deep River terminal fishery area. 


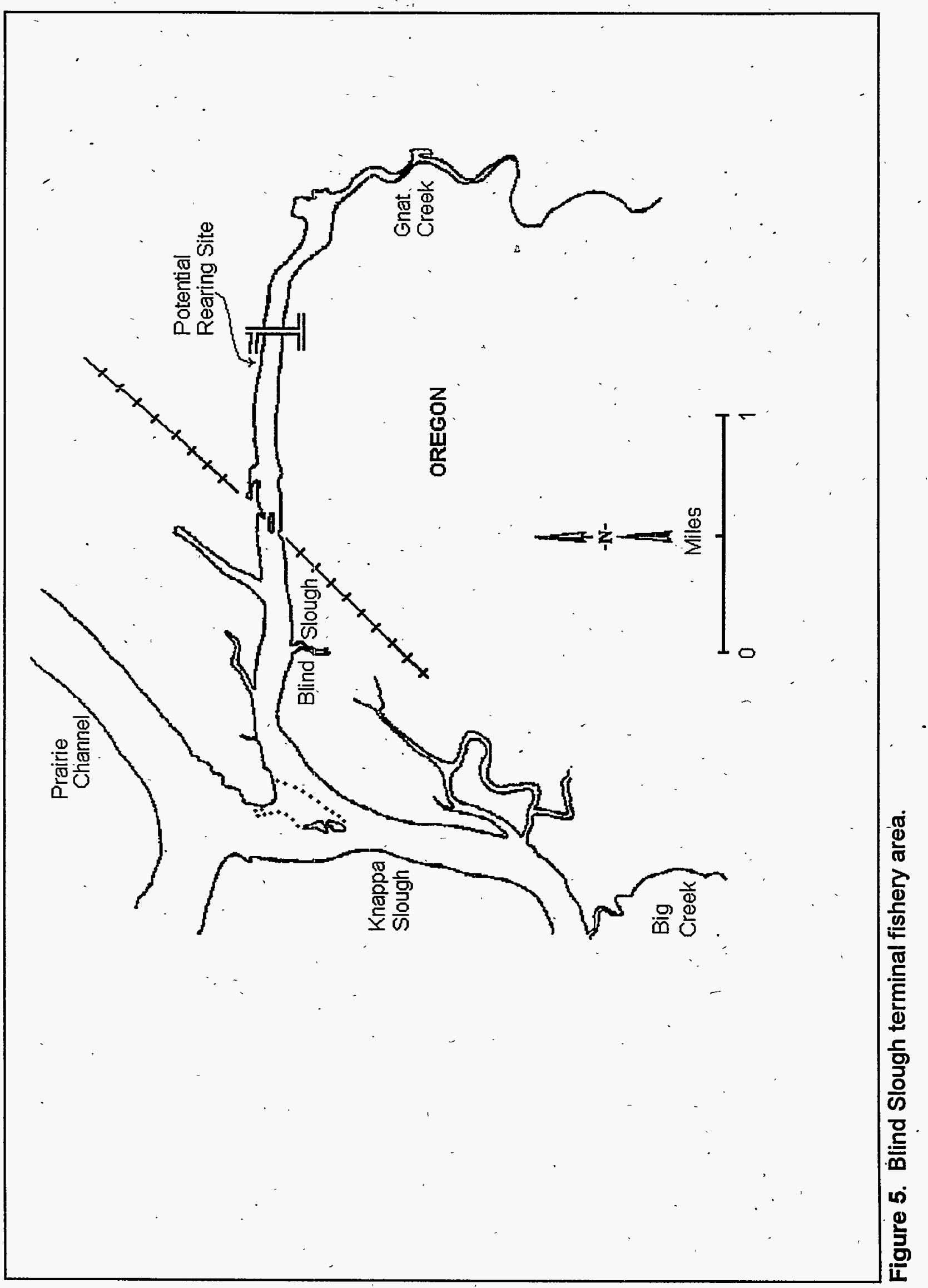




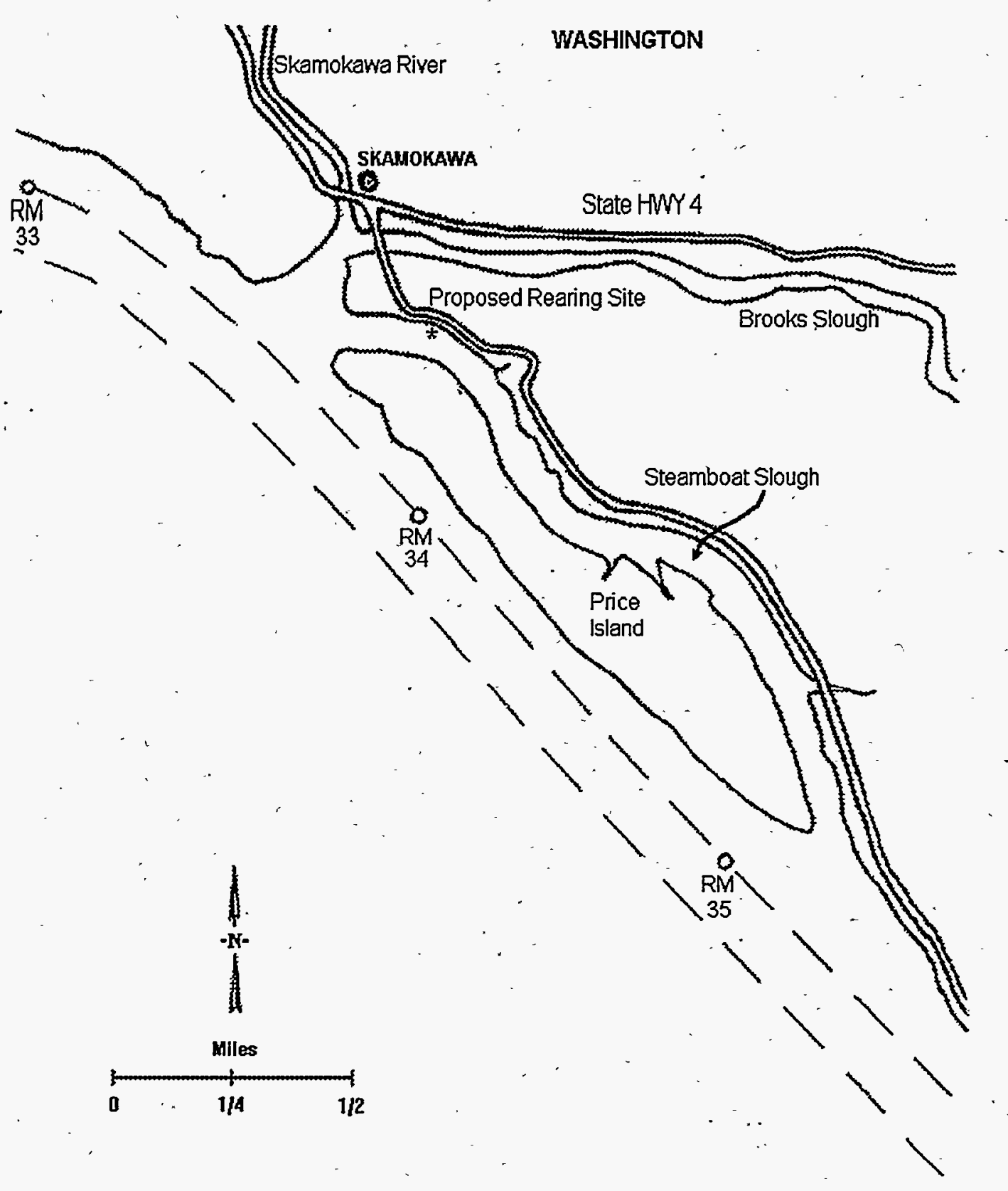

Figure 6. Steamboat Slough terminal fishery site. 


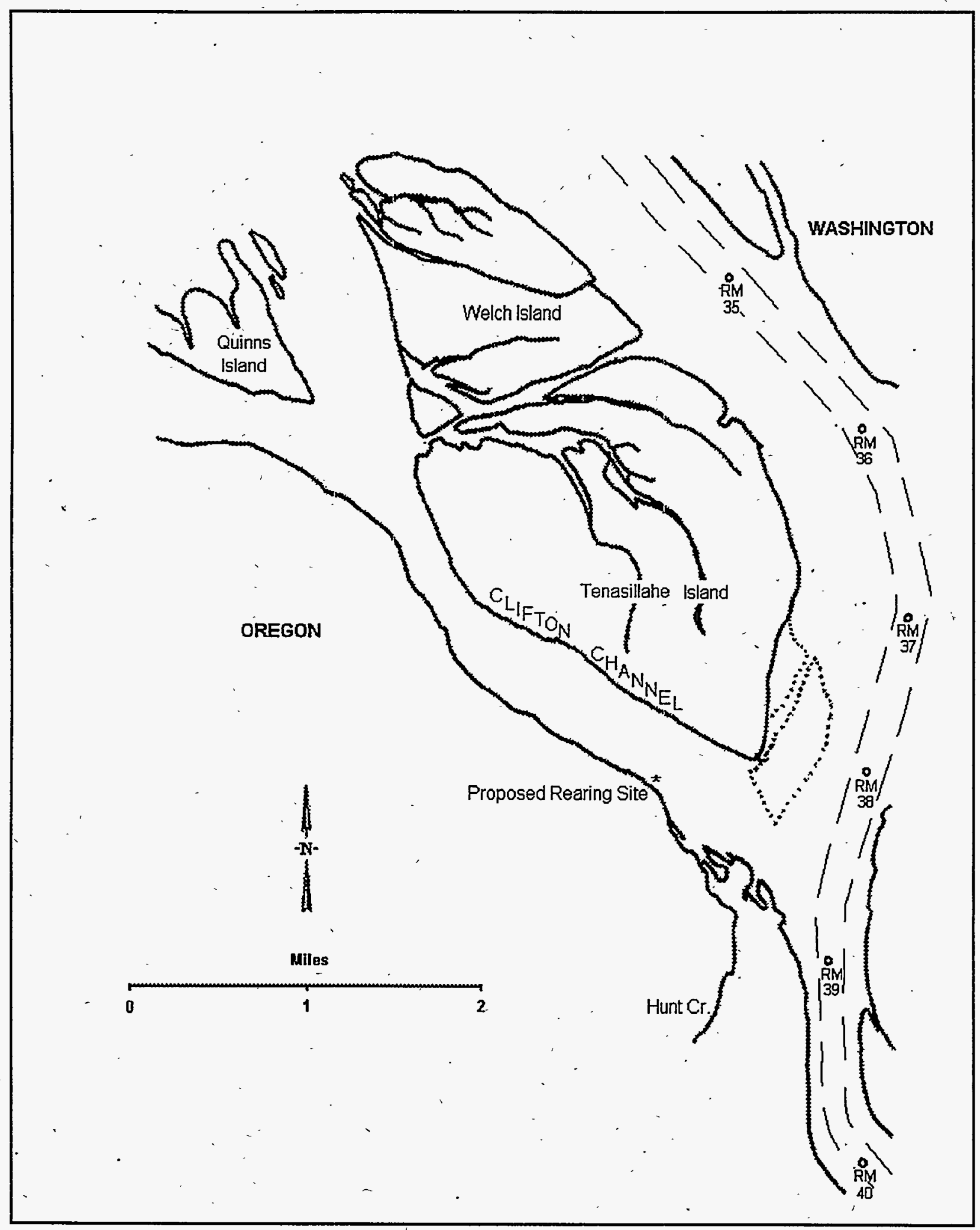

Figure 7. Clifton Channel terminal fishery area. 


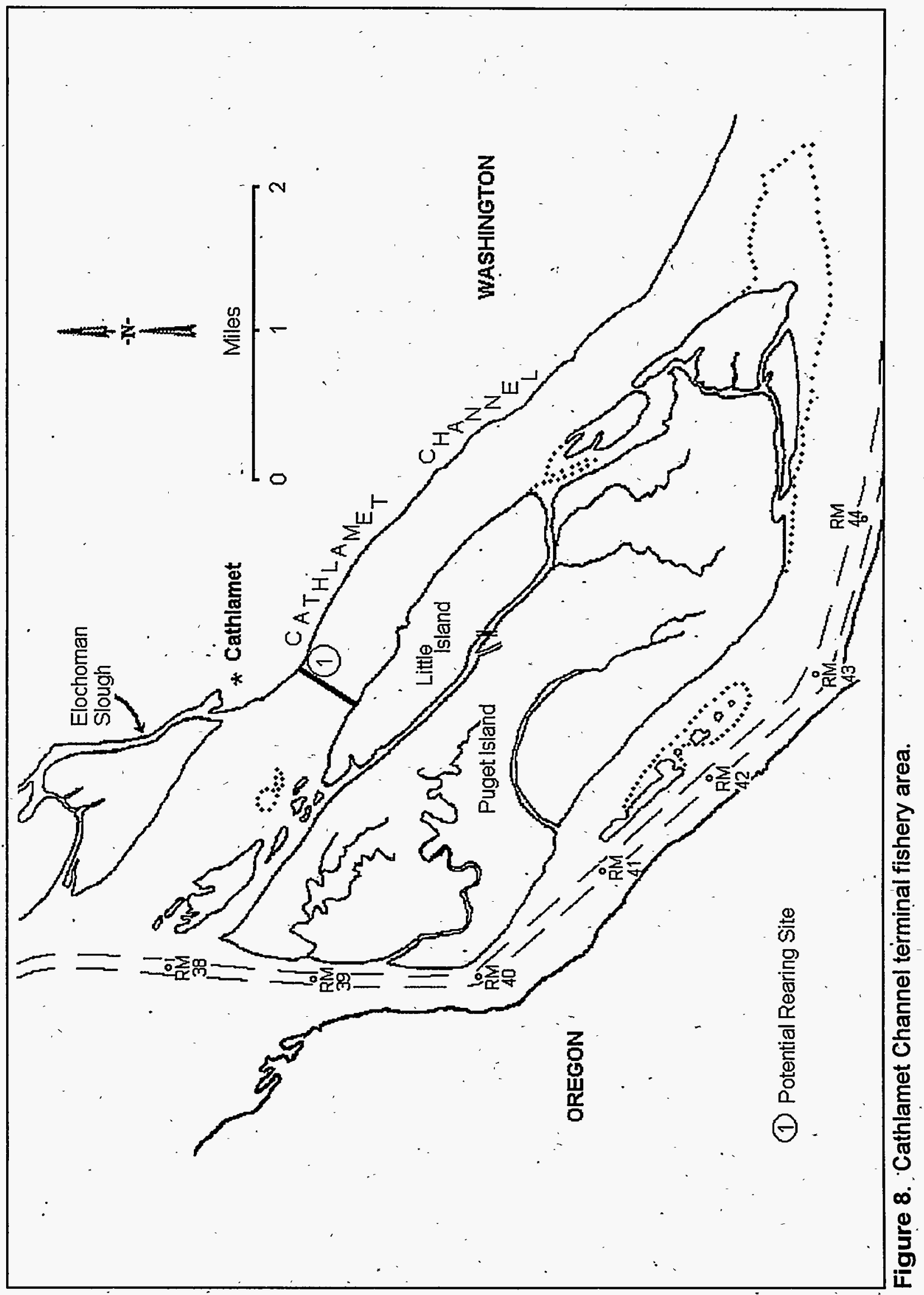


